NOTICE: this is the author's version of a work that was accepted for publication in ECOLOGICAL ECONOMICS. Changes resulting from the publishing process, such as peer review, editing, corrections, structural formatting, and other quality control mechanisms may not be reflected in this document. Changes may have been made to this work since it was submitted for publication. A definitive version was subsequently published in ECOLOGICAL ECONOMICS, Vol 146 (2018) pp. 447-474 https://doi.org/10.1016/j.ecolecon.2017.11.016 


\title{
The role of community involvement mechanisms in reducing resistance to energy infrastructure development*
}

\author{
Marie Hyland ${ }^{\dagger} \quad$ Valentin Bertsch ${ }^{\ddagger}$
}

October 2017

Please cite as: Hyland, M. \& Bertsch, V. (2018). The role of community involvement mechanisms in reducing resistance to energy infrastructure development. Ecological Economics, 146, pp. 447-474. DOI: 10.1016/j.ecolecon.2017.11.016.

\begin{abstract}
Across the EU, significant investments are being made in renewable generation and grid technologies, however, policy makers and planners are frequently met with resistance from local communities to proposed infrastructure development. Offering some form of involvement to the affected communities may reduce objections and minimise project delays. We carry out a nationally-representative survey of Irish citizens to analyse how different involvement methods affect acceptance. Ireland is a useful case study because of its high RES-E targets. Survey respondents are presented with four involvement models for the local construction of a wind farm, and two for the local development of the transmission grid. We find a preference for schemes in which people receive financial compensation without sharing in the ownership and associated risks of project development. Our econometric analyses show that socio-demographic characteristics such as age and income are significant predictors of people's acceptance under different schemes. Moreover, we find that the satisfaction with local planning procedures and the trade-off people make between environmental sustainability and economic competitiveness are consistently associated with people's attitudes. Such evidence can help policy makers better understand and design policies to minimise resistance to energy infrastructure development.
\end{abstract}

Keywords: Renewable energy, Grid expansion, Social acceptance, Community compensation, Community involvement

*Acknowledgements: Hyland and Bertsch acknowledge funding from the Energy Policy Research Centre of the Economic and Social Research Institute. The usual disclaimer applies.

${ }^{\dagger}$ Corresponding author. Economic and Social Research Institute and Trinity College Dublin. Email: marie.hyland@esri.ie

${ }^{\ddagger}$ Economic and Social Research Institute and Trinity College Dublin. Email: valentin.bertsch@esri.ie 


\section{Introduction}

In order to meet greenhouse gas reduction and renewable expansion targets, significant investments in electricity generation from renewable sources (RES-E) and grid technologies are necessary across the EU. However, while citizens generally express acceptance of these investments on an abstract or theoretical level (Wüstenhagen et al., 2007; Van der Horst, 2007), policy makers and planners are frequently met with resistance from local communities to specific energy infrastructure development proposals. ${ }^{1}$ A potential way of reducing the gap between acceptance of infrastructure on an abstract level and acceptance in the face of actual development, is to offer some form of compensation to the affected communities.

There are numerous methods of compensating and involving local communities in infrastructure development, however, evidence on which methods are most effective at increasing acceptance is scant. Furthermore, most existing research focuses on showing that community involvement or compensation schemes can reduce local opposition rather than exploring what drives the acceptance of energy infrastructure development or increases acceptance under different schemes, which is the primary contribution of our paper. Through our analysis, we aim to shed light on the following issues: How do citizens feel about proposed expansion of renewable electricity infrastructure in their locality? Relative to a situation in which the community is not involved or compensated for infrastructure development, do their opinions change when different community involvement schemes are proposed? Which socio-demographic characteristics and attitudinal factors are significantly correlated with acceptance levels, or increased acceptance, under a range of hypothetical community involvement schemes? As there is no available data, based on either revealed or stated preferences, that allow us to quantitatively answers these questions, we conduct a nationallyrepresentative survey to analyse people's acceptance of energy infrastructure development under different involvement schemes based on stated preferences.

Ireland provides a useful case study in this regard because of its high RES-E targets, and because of the significant energy infrastructure expansion that reaching these targets will necessitate. However, despite its targets and the high RES-E potential available, research on the acceptance of energy-related infrastructure in Ireland is rare to date. The dominating RES-E technology in Ireland is onshore wind, the further development of which requires an accompanying expansion of the transmission grid. Given the interdependency of these two technologies, we present respondents with involvement models for both the local construction of a wind farm, and the local development of the transmission grid. We analyse the responses to our survey using different econometric models, namely an ordered-logit and a logit model, and distinguish between external and

\footnotetext{
${ }^{1}$ See, for example, Bell et al. (2005); Zoellner et al. (2008); Raven et al. (2009); Devine-Wright (2011); Musall and Kuik (2011); Guo et al. (2015); Rand and Hoen (2017).
} 
internal factors driving the respondents' acceptance of hypothetical infrastructure development, and increases in acceptance levels, under different involvement schemes.

The challenges related to local acceptance and opposition of energy infrastructure development have been discussed by Wolsink (2000), Burningham (2000), Devine-Wright (2005) and Wüstenhagen et al. (2007), amongst others. Existing research on local acceptance and opposition has highlighted the importance of trust (Aitken, 2010), regulations (Battaglini et al., 2012) and perceived (in)justice in terms of how the costs and benefits of projects are shared (Huijts et al., 2012; Ciupuliga and Cuppen, 2013). There is also a large and growing literature emphasising the role of transparent communication, community consultation and information sharing in minimising opposition to infrastructure development (Zarnikau, 2003; Beddoe and Chamberlin, 2003; Gross, 2007; Hobman et al., 2012; National Economic and Social Council, 2014; Rand and Hoen, 2017). Notably, it has been found that offering some form of compensation or involvement to the affected communities, e.g., through full or shared ownership, may reduce objections and minimise project delays (Ek and Persson, 2014; Brennan and Van Rensburg, 2016; Brennan et al., 2017). While Goedkoop and Devine-Wright (2016) emphasise that shared ownership should not be regarded as a silver bullet, they do acknowledge that it may be very helpful if trust between the actors can be ensured.

There have, to date, been a few analyses specific to the Irish context. For example, SEI (2003) analysed the Irish public's attitude towards the development of wind farms at a time where the nation-wide installed wind power capacity was around $200 \mathrm{MW}$ (which increased to over $2800 \mathrm{MW}$ by 2016); however, the analysis of community involvement schemes was not very detailed. Later, the National Economic and Social Council (2014) reviewed national legislation and international literature in relation to wind power development and outlined different community involvement schemes, though not providing a quantitative analysis. Moreover, Van Rensburg et al. (2015) investigate the probability of wind farm planning approval, while Brennan and Van Rensburg (2016) conduct a discrete choice experiment to explore the trade-offs people make to allow for wind power developments in their localities. What these studies have in common is that they focus on wind power without considering the necessary accompanying expansion of the transmission grid.

Despite the fact that a number of papers have considered energy infrastructure expansion, and local opposition to it, there has not, to date, been a comprehensive analysis of the drivers of acceptance of both wind and transmission infrastructure under a range of involvement schemes. Such evidence is needed to help policy makers better understand and design policies to minimise perceived injustices of infrastructure development; addressing this knowledge gap is the fundamental contribution of our analysis.

This paper is structured as follows. In section 2 we discuss the survey design, and how it was informed by previous analyses from the literature. In section 3, we describe the data collection 
process and present the econometric techniques used for our analysis. In section 4 we outline the survey findings and the results of our econometric analysis; a more detailed discussion of these results is presented in section 5. In section 6, we summarise the main findings and derive conclusions. Further details of the questionnaire are presented in Appendix A, while Appendix B provides additional results.

\section{Designing the questionnaire}

\section{$2.1 \quad$ Background}

There is a large and growing literature on institutional aspects and ownership structures of renewable energy or grid development projects, which analyse community involvement at very different levels. $^{2}$ We utilised this body of knowledge to inform the design of our questionnaire. One particularly relevant analysis is the work of Brennan and Van Rensburg (2016). Focussing on wind farm development in Ireland using a discrete choice experiment, the authors find that local acceptance of a hypothetical wind farm development is positively influenced by financial discounts that local residents receive on their electricity bills. The involvement analysed by Brennan and Van Rensburg (2016) did not represent a great depth of engagement, however, as only financial compensation was offered to the participants in their choice experiment. The authors also analysed the impact of (early) community consultation and the presence of a community representative who regularly meets and negotiates with the developers; the authors find that expected levels of compensation are reduced when such a person is present.

Analysing the impact of a deeper level of involvement, Warren and McFadyen (2010) compare public attitudes towards existing community-owned versus developer-owned wind farms in two Scottish communities and find that attitudes towards wind power are more positive in the community that owns the wind farm. What the studies by Brennan and Van Rensburg (2016) and Warren and McFadyen (2010) have in common is that they study the impact of a single community involvement scheme (a rather shallow involvement in the former and a deeper involvement in the latter case), not allowing for comparisons between different schemes.

Ek and Persson (2014) analyse and compare different wind farm ownership models in Sweden using a discrete choice experiment. The authors include hypothetical projects owned by the state or by private developers (not offering involvement or compensation to residents), as well as municipality-owned and shared ownership projects (i.e., shared ownership between private developers and the municipality/residents). They find that respondents prefer wind farms fully or

\footnotetext{
${ }^{2}$ See, for example,(Toke, 2005; Gross, 2007; Jobert et al., 2007; Walker and Devine-Wright, 2008; Bauwens et al., 2016; Schreuer, 2016; Goedkoop and Devine-Wright, 2016; Walker and Baxter, 2017; Devine-Wright et al., 2017).
} 
partially owned by the municipality; indicating a preference for deeper levels of involvement.

While there have been a number of studies exploring different nuances of compensation and involvement schemes for wind farms, which we can use to guide our analysis, research on involvement schemes for transmission grid developments is rather rare. The few exceptions are Cohen et al. (2016) and Devine-Wright and Batel (2013) who, among other things, explore the impact of compensation schemes to communities or residents that are affected by hypothetical grid developments across the EU and in the UK respectively. However, deeper levels of involvement are typically not considered in the case of grid development, as the responsibility to operate and maintain the grid and ensure supply reliability cannot be given to individual communities.

Based on the different community involvement and compensation schemes studied in the literature, our survey included three distinct categories of variables: Category 1 comprises the dependent variables, while Categories $2 \& 3$ are aimed at eliciting the explanatory (independent) variables. Further details of the survey are provided in Appendix A.

\subsection{Outcome variables}

Survey Question Category 1 (dependent variables):

We asked respondents how willing they would be to accept the development of energy infrastructure (focussing on wind farms and transmission lines) in their local community in the presence of either no community involvement or one of a set of hypothetical schemes (described in detail to the respondents), which varied by their depth of community involvement. They were asked to express their willingness on a 5-point scale from "Unwilling" to "Willing". The specific involvement schemes proposed in our survey follow those that were outlined by National Economic and Social Council (2014). For this purpose, the following hypothetical schemes were presented to the respondents.

- Community benefit scheme: These are voluntary agreements between project developers and local communities. The developers pay a fixed amount to local communities, e.g., for the development of a wind farm or a transmission line for a predetermined amount of time. The communities would have limited involvement in the project and no associated financial risks. The payments could be made directly to households in the locally affected communities, or paid into a local fund which could be used, for example, to finance local energy efficiency projects. (Applicable to wind + grid)

- Equity involvement: Local residents would have the opportunity to share in the risks as well as the potential profits of wind farm or transmission line development projects. Residents who purchase a stake in the project would share in the financial returns. An example of equity 


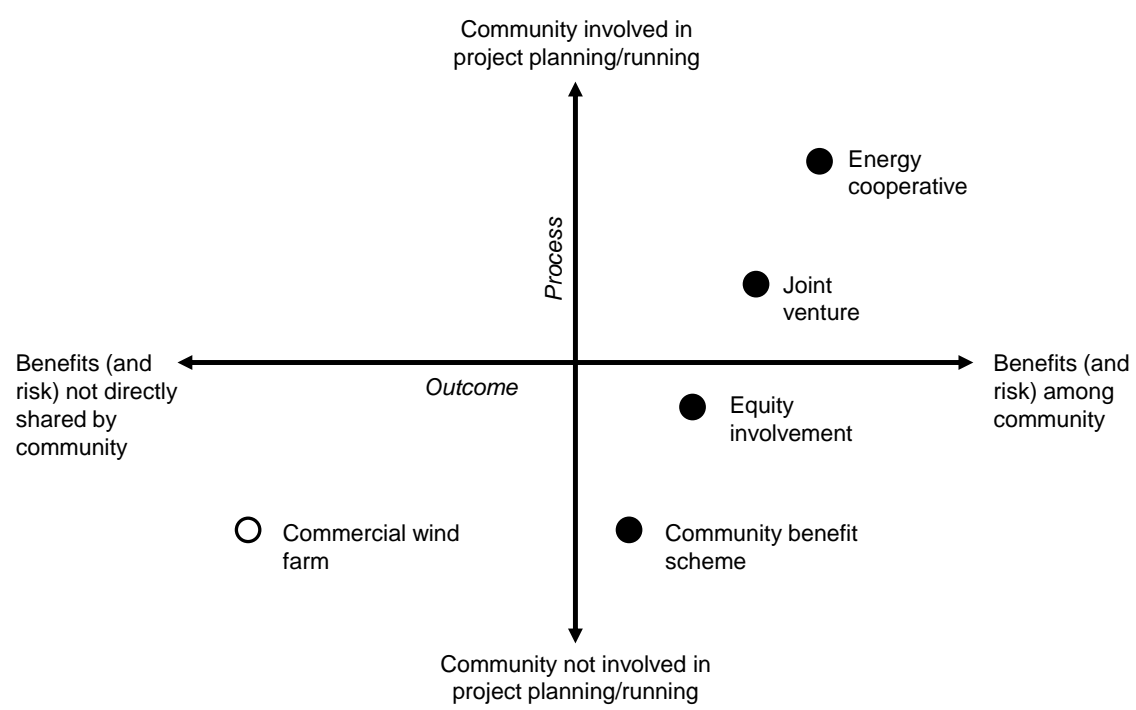

Figure 1: Characteristics of considered community involvement schemes (based on the characterisation of community energy by Walker and Devine-Wright (2008) and Goedkoop and Devine-Wright (2016))

involvement is a scheme currently in place in Denmark in which $20 \%$ ownership of the wind farm must be offered to local residents. (Applicable to wind + grid)

- Joint ventures: Local communities would work with commercial operators to develop a wind farm and agree jointly on its (shared) ownership and management structure. These may involve, within a given wind farm, individual wind turbines that are separately owned by the communities. Here the turbines are individually owned but there is joint responsibility between the community and the developers in terms of overall project risks. (Applicable to wind only)

- Energy cooperatives: Energy cooperatives, communities, or local community organisations, would have full ownership of the wind development projects and take all, or most of, the profits as well as the risks associated with project development. The cooperatives would operate the wind farms and, as owners, would take responsibility for their ongoing development and maintenance. (Applicable to wind only)

Based on the characterisation of community energy by Walker and Devine-Wright (2008) and Goedkoop and Devine-Wright (2016), Figure 1 illustrates how the levels of financial and procedural community involvement vary between the considered schemes. Distinguishing between processes (the $\mathrm{Y}$ axis) and outcomes (the $\mathrm{X}$ axis), Walker and Devine-Wright (2008) define community energy as the upper right quadrant of the diagram in Figure 1, whereas a commercial wind farm 
would be positioned in the lower left quadrant. Of the four schemes we consider in this study, two mainly focus on the (financial) outcome dimension (community benefit scheme and equity involvement) while the other two combine aspects of financial and procedural involvement (joint ventures and energy cooperatives).

\subsection{Explanatory variables}

Researchers have been studying people's behaviour and attitudes in relation to the use of natural resources and the environment, and what influences these, for many years. We follow the conceptual structure of Guagnano et al. (1995), who distinguish between external (demographic, economic, structural) and internal (attitudes, beliefs) variables driving people's attitudes. Once again, we build on the existing body of research in this area to inform the choice of explanatory variables to include in our questionnaire.

Survey Question Category 2 (independent, external variables):

Existing studies have found a large variety of socio-demographic characteristics to be significant explanatory variables in different contexts. For instance, Cohen et al. (2016) find the acceptance of transmission line expansion decreases with age, while Vorkinn and Riese (2001) find lower acceptance of hydro power among females and households with higher incomes. Moreover, Bidwell (2013) finds that education has a significant direct effect on people's attitude towards wind power. In addition, length of residence, and area of residence (i.e., urban vs. rural) were found to have a significant effect on landscape-related and place-related perceptions and preferences, as well as energy technology acceptance (Anton and Lawrence, 2014; Devine-Wright, 2012; Devine-Wright and Batel, 2013).

Based on these previous analyses, we asked respondents to provide information on their sociodemographic characteristics as outlined in Table 1. Further details (e.g., on the response categories) are provided in Appendix A.

\section{Survey Question Category 3 (independent, internal variables):}

In terms of internal variables, some theoretical as well as empirical findings suggest a link between environmental principles and behavioural intentions, as well as acceptance of energy-related technologies (Stern et al., 1995; Poortinga et al., 2006; Bidwell, 2013). Political preferences have also been found to be correlated with opinions about energy infrastructure (Populus, 2005; Devine-Wright and Batel, 2013). Moreover, Dietz et al. (1998) find that the trade-off people make between economic and environmental considerations is a significant explanatory variable. In addition, trust,

\footnotetext{
${ }^{3}$ This provided a generalisation of the economic-environmental trade-off discussed by Dietz et al. (1998).
} 
Table 1: Overview of independent variables elicited in the survey

\section{External variables Internal variables}

- Age

- Preferences of, and pairwise trade-offs between, national energy policy

- Education

objectives (economic competitiveness, environmental sustainability,

- Income

- Employment

reliability of supply, and social acceptance/impact $)^{3}$

- Gender

- Priorities and perceived impact assessments (i.e., assessments of the

- Region of residence

within Ireland impacts of the hypothetical developments, as perceived by the

- Tenure

respondent) of various technology-specific criteria (e.g., visual landscape and noise impacts)

- Length of residence

- Satisfaction with the existing local planning procedures, in terms of

- Area of residence

(urban vs. rural)

how local residents are involved when infrastructure projects are

developed (providing an insight into satisfaction with the status quo, and the extent to which citizens trust current processes)

perceived fairness, and satisfaction with local planning procedures were found to have a significant impact on people's acceptance (Furby et al., 1988; Aitken, 2010; Terwel et al., 2011; Huijts et al., 2012; Ciupuliga and Cuppen, 2013). Subjectively perceived impacts of energy technology developments on their surroundings have also been found to significantly drive people's attitudes. Particularly for wind turbines and power lines, the perceived visual impact on the landscape has been identified as one of the most important predictors of opinions (Furby et al., 1988; Wolsink, 2000; SEI, 2003; Cotton and Devine-Wright, 2011; Devine-Wright and Batel, 2013; Bidwell, 2013). Moreover, the perceived impacts on ambient noise (Furby et al., 1988; Wolsink, 2000; SEI, 2003), health and safety (Furby et al., 1988; Poortinga et al., 2006; Soini et al., 2011) and the local economy, local employment and the local environment (SEI, 2003; Bidwell, 2013) have been identified in previous studies on wind power and transmission lines.

The right column of Table 1 provides an overview of the internal variables elicited in the survey; in our econometric analysis we estimate their relationship to infrastructure acceptance. Further details are provided in Appendix A.

For the items under category 3, we use well-established elicitation methods from the field of decision analysis as follows: National energy policy preferences were elicited by asking respondents to provide pairwise trade-off statements of the relative importance of energy policy objectives at a national level. ${ }^{4}$ These judgements were provided by pairwise comparisons as in AHP ("analytic hierarchy process", see Saaty (1980)). The assessments related to the technology-specific criteria were elicited following a two-step procedure. In the first step, the participants were asked to

\footnotetext{
${ }^{4}$ These trade-off statements can be viewed as a generalisation of the trade-off between the economy and the environment, which Dietz et al. (1998) discuss. Pairwise trade-offs can be used to determine the relative order between alternatives; this concept is discussed in greater detail by Kułakowski (2015), Bertsch et al. (2016) and Bertsch et al. (2017).
} 
provide their subjective views of the importance of a number of technology-specific criteria (impact on landscape, noise, etc., see Appendix A) individually on a 5-point scale. On this basis, normalised weights were calculated as in SWING weighting (Edwards and Von Winterfeldt, 1986; Edwards, 1977). In the second step, the participants were asked to assess the subjectively perceived impact of different energy infrastructure technologies with respect to these technology-specific criteria on a scale from -2 (negative) to 2 (positive). The SWING weights and corresponding impact assessments are interacted to calculate the technology-specific criteria's overall impacts. This allows us to explicitly disentangle the relative importance of a particular driver and the subjective impact assessment of a given technology with respect to this driver. ${ }^{5}$ These interactions yield the perception of the overall impacts of the various technologies on the surroundings. For example, the overall impact of wind turbines on the landscape is a combination of the subjective importance given to landscape considerations, and the subjective opinion on the impact of wind turbines on the landscape.

\section{Data and Methods}

\subsection{Data collection}

In order to explore how willing people are to accept the development of energy infrastructure in their local communities, we developed, over a number of iterations, an online survey based on stated preference questions. ${ }^{6}$ An alternative method of answering these questions would have been to use revealed preferences. While revealed preferences have the advantage of being based on observed decisions, because we are analysing compensation schemes that are not yet widely used, hedonic regressions (a commonly used form of revealed preference analysis) are not possible. Furthermore, carrying out an experiment and conducting an analysis based on revealed preferences in this manner is not realistic in the current context. After conducting a number of pre-tests to ensure survey quality, a nationally representative panel of the Republic of Ireland was drawn $(n=1,414)$ using the panel book of Research Now, an international company specialising in online consumer surveys with approximately 54,000 panellists across Ireland. The survey included two

\footnotetext{
${ }^{5}$ The formula for this interaction is as follows: Let $n \in \mathbb{N}$ be the number of participants, $k \in\{1, \ldots, n\}$ be the participant index, $m \in \mathbb{N}$ be the number of technologies, $j \in\{1, \ldots, m\}$ be the technology index, $l \in \mathbb{N}$ be the number of impact criteria and $i \in\{1, \ldots, l\}$ be the criteria index. Moreover, let $w_{i}^{k} \in[0,1]$ be the (SWING) weight assigned to criterion $i$ by participant $k$ and $v_{i j}^{k} \in\{-2,-1,0,+1,+2\}$ be the subjective impact assessment of technology $j$ with respect to criterion $i$ as perceived by participant $k$. The overall impact $\Omega_{i j}^{k}$ of technology $j$ on criterion $i$ according to participant $k$ can then be evaluated as $\Omega_{i j}^{k}=w_{i}^{k} \cdot v_{i j}^{k}$.

${ }^{6}$ For an overview of the discussion on theories and elicitation strategies behind stated versus revealed preferences, see the works by Ben-Akiva et al. (1994), Kim et al. (2006) and Carson and Louviere (2011), furthermore, a history of the use of these approaches to value environmental amenities is provided by Pearce (2002).
} 
screening questions to ensure data quality (Galesic and Bosnjak, 2009) and block randomisation to avoid order effects (Sills and Song, 2002; Podsakoff et al., 2003). The screening questions are provided in Appendix A. Developing the survey over a number of iterations ensured a high-quality final sample, comprised of $n=1,044$ respondents. The exact sample size may differ for certain questions as the respondents were given the option to choose "No experience or limited knowledge" for some questions.

\subsection{Econometric methodology}

In order to understand how the overall willingness to accept infrastructure development under different community involvement mechanisms, as well as the increased acceptance under such schemes, are explained by external (socio-demographic) and internal (energy policy preferences, technology-specific criteria, satisfaction with planning procedures) variables, we apply two econometric models, as outlined below.

\subsubsection{Ordered logit model}

As the responses follow an ordered sequence, we use an ordinal regression model to explore which of the external (socio-demographic) and internal (attitudinal) variables described in section 2.3 are significantly correlated with the acceptance of wind energy or power grid development under different schemes. The model is characterised by Equation 1.

$$
\operatorname{Pr}\left(Y=N \mid X_{1}, X_{2}, \ldots, X_{k}\right)=F\left(\beta_{0}+\beta_{1}+\beta_{2}+\ldots+\beta_{k}\right)
$$

$\mathrm{N}$ ranges in value from 1 to 5 where 1 is "Unwilling" and 5 is "Willing". The $X$ 's represent the external and internal explanatory variables in our model, $\mathrm{F}$ is the standard logistic distribution, and the $\beta$ terms are the coefficients on the explanatory variables.

The ordered logit model requires that the so-called proportional odds assumption (POA) holds (Long and Freese, 2006). Thus, before running the ordered logit, we test the POA, using tests discussed by, e.g., Peterson and Harrell Jr (1990) and Williams et al. (2006). In those cases where the POA does not hold, we apply a generalised order logit model (Williams et al., 2006; Williams, 2006); this model is fundamentally the same as the ordered logit except that it allows the coefficients on the independent variables to differ for different levels of the dependent variable. ${ }^{7}$

\footnotetext{
${ }^{7}$ As outlined by Long and Freese (2006), the POA means that running an ordered logit is equivalent to running $J-1$ binary regressions in which the coefficients on the $X$ variables are the same across each of the $J-1$ regressions. If the coefficients are not statistically equivalent across the $J-1$ regressions, the POA does not hold, and the use of an ordered logit model is not appropriate. The generalised ordered logit, on the other hand, allows the coefficients on the $X$ variables to differ for different levels of the $Y$ variable (i.e., across the $J-1$ regressions) where appropriate. A detailed description of this model is provided by Williams (2006).
} 
After running the model outlined by equation 1 , we convert the $\beta$ coefficients into marginal effects (Chernozhukov et al., 2009). These represent the probability change that someone will report a given opinion when the value of a particular independent variable increases by one unit, holding all other independent variables at their respective mean values.

\subsubsection{Logit model}

In addition to examining what factors are significantly associated with people's willingness to accept energy infrastructure development under different forms of community involvement, we check whether the different mechanisms lead to an increase in acceptance when compared to the case where no compensation is available. For this purpose, we define an "acceptance increase" dummy variable. This variable takes a value of one for a certain involvement/compensation mechanism if a respondent indicates a higher acceptance of the development of a wind (or grid) project relative to the case where no mechanism is in place. Otherwise, the variable takes a value of zero. As the variable only takes a value of zero or one, we use a logit model (Long and Freese, 2006) to analyse which variables significantly predict an increase in acceptance.

The dependent variable, $y_{i}$, represents increased acceptance under a particular involvement scheme (relative to a situation where there is no scheme in place). The logit model assumes that underlying this observed $y_{i}$ there is an unobserved latent variable, $Y^{*}$, such that:

$$
Y^{*}=X \beta+\epsilon
$$

In a logit model we observe:

$$
y_{i}= \begin{cases}0 & \text { if } y_{i}^{*} \leq 0 \\ 1 & \text { if } y_{i}^{*}>1\end{cases}
$$

We are looking at the probability of observing a given value of $y_{i}$, where the $\mathrm{Xs}_{\mathrm{s}}$ are the explanatory variables (the socio-demographics, energy policy preferences and technology-specific factors) and the $\beta$ terms represent the coefficients on these variables. Once again, we convert the coefficients into marginal effects when presenting the results.

\section{Results}

\subsection{Survey results}

The results of our survey show that, when considering the various involvement schemes proposed, the willingness to accept the local development of infrastructure is highest under community benefit 

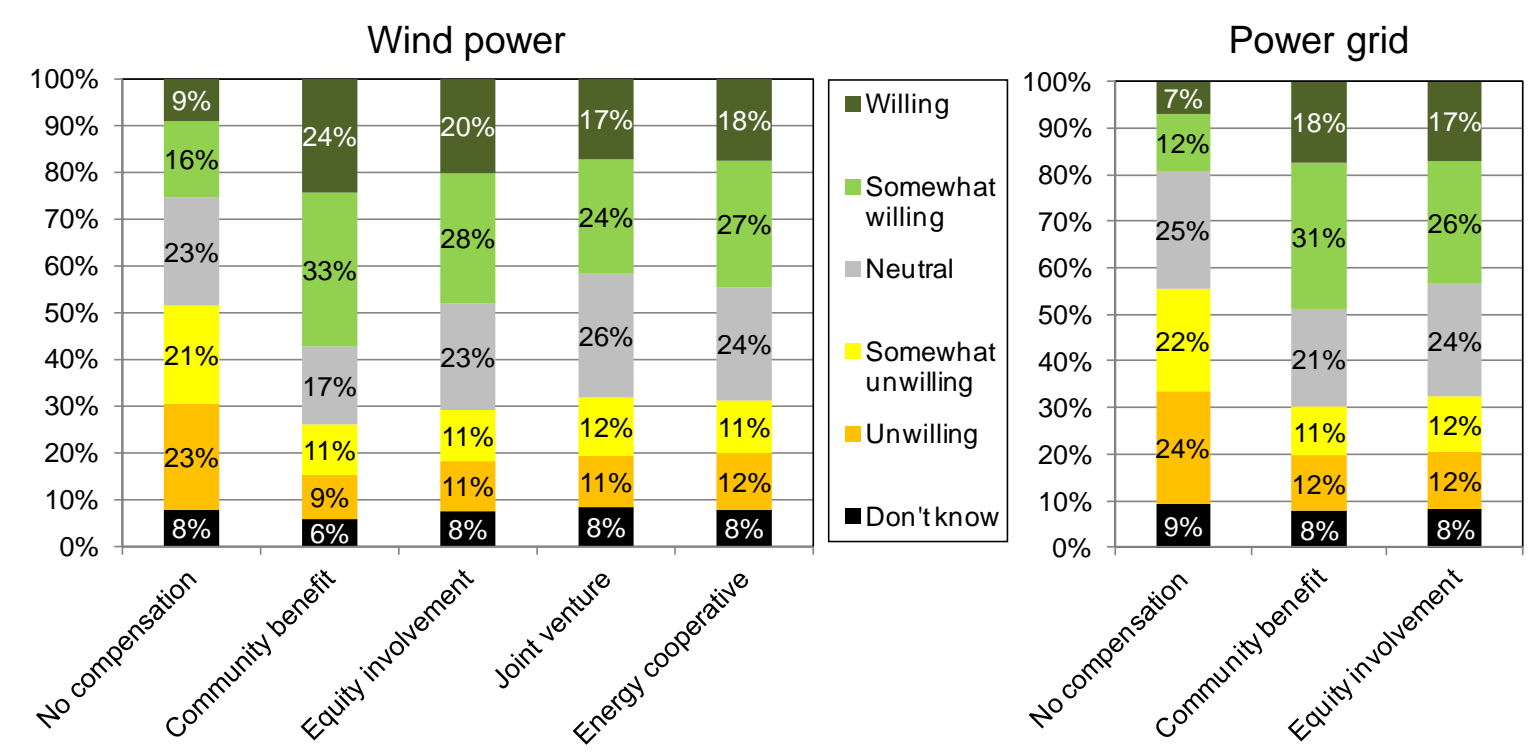

Figure 2: Acceptance rate of local wind farm (left) and transmission grid (right) development under various involvement schemes

schemes (CBS); of the various schemes presented to survey respondents, the CBS has the lowest level of involvement. As figure 2 shows, under the CBS over half of the respondents indicated some degree of willingness (either "willing" or "somewhat willing") to accept the local construction of a wind farm, compared to just over a quarter when there was no involvement scheme proposed. As the depth of engagement increases, Figure 2 shows a decline in acceptance levels from the CBS through to joint ventures and a slight increase in acceptance levels when moving from joint ventures to energy cooperatives.

A similar picture emerges when we consider possible involvement schemes for local grid development projects. ${ }^{8}$ Figure 2 shows low levels of acceptance when no involvement scheme is in place, and that involvement via a CBS is more popular relative to equity involvement. Acceptance levels of grid development are slightly lower than acceptance of wind farms. Community involvement schemes do appear to lower resistance levels however; while $46 \%$ of respondents said that they would be "unwilling" or "somewhat unwilling" to accept the local development of transmission grid when they are not offered any involvement, this drops to $23 \%$ and $24 \%$ under CBS and equity involvement.

An alternative way of considering the effectiveness of involvement schemes at reducing resistance is to look at how people's willingness to accept wind farm or grid development changes when a scheme is proposed, relative to a situation with no scheme in place. As Figure 3 shows, acceptance

\footnotetext{
${ }^{8}$ As noted previously, due to the technical nature of grid operation, only two potential compensation models are presented.
} 

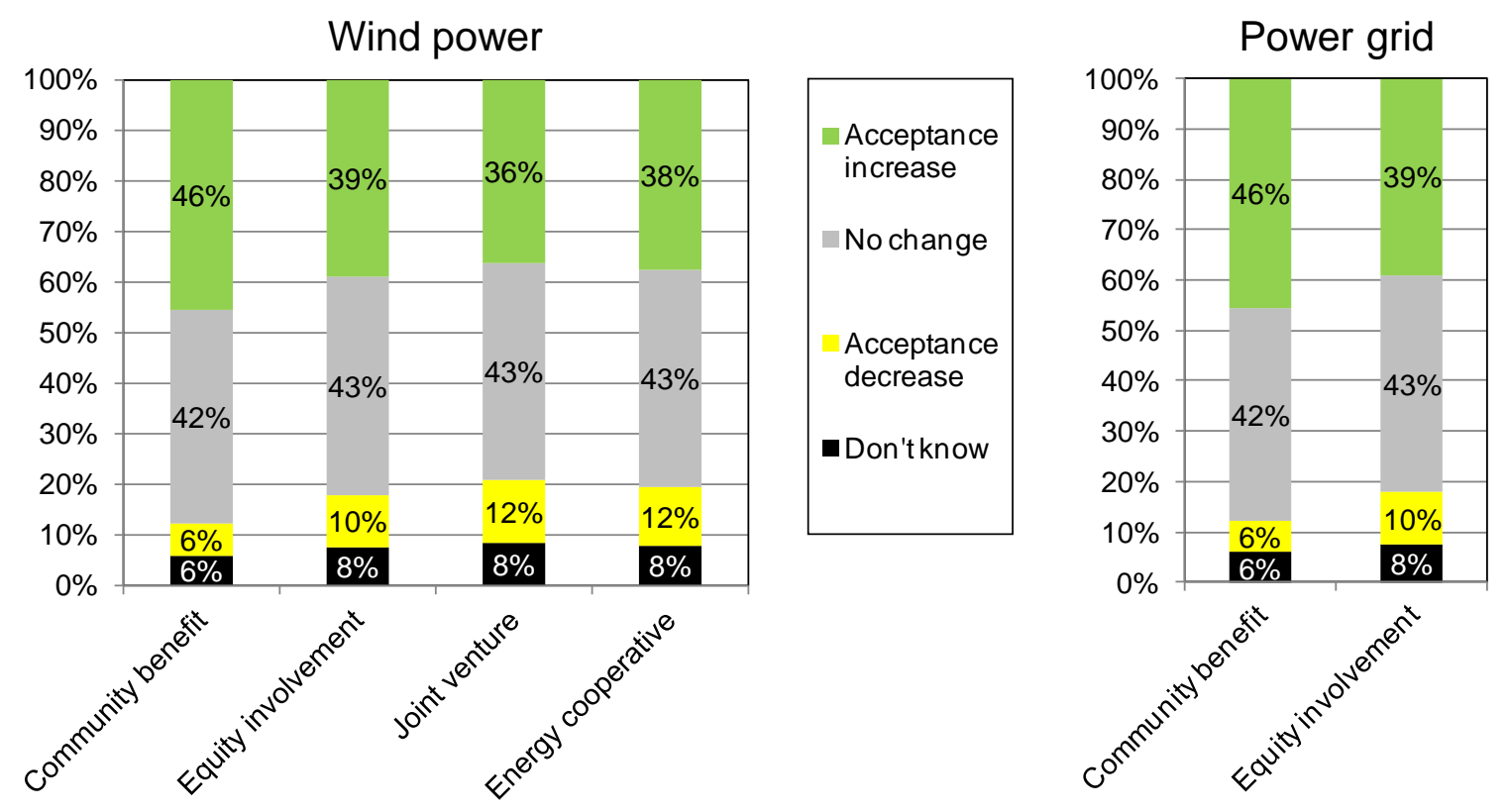

Figure 3: Change of acceptance of local wind farm (left) and transmission grid (right) development for different involvement schemes compared to no compensation being in place

rates increase by $46 \%$ for both wind farm and grid development when communities are given the hypothetical option of being involved via a CBS. Also of particular note is that for a large proportion of the population ( $42 \%$ to $43 \%$ ) acceptance does not change under the proposed involvement schemes. In the next section we consider the characteristics of respondents that, according to our econometric analyses, are significantly correlated with the opinions summarised in Figures 2 and 3.

\subsection{Econometric Analysis}

The econometric results reveal which characteristics are significantly related to people being more favourably disposed towards wind and grid development projects when there is no involvement scheme in place, and under each of the proposed schemes. The full results tables are provided in Appendix A; here we focus on the characteristics that are significant predictors of willingness to accept the local construction of a wind farm or a transmission line under each involvement mechanism (including no involvement); tables 2-4 provide a synopsis of the results for wind farm and grid development respectively. 


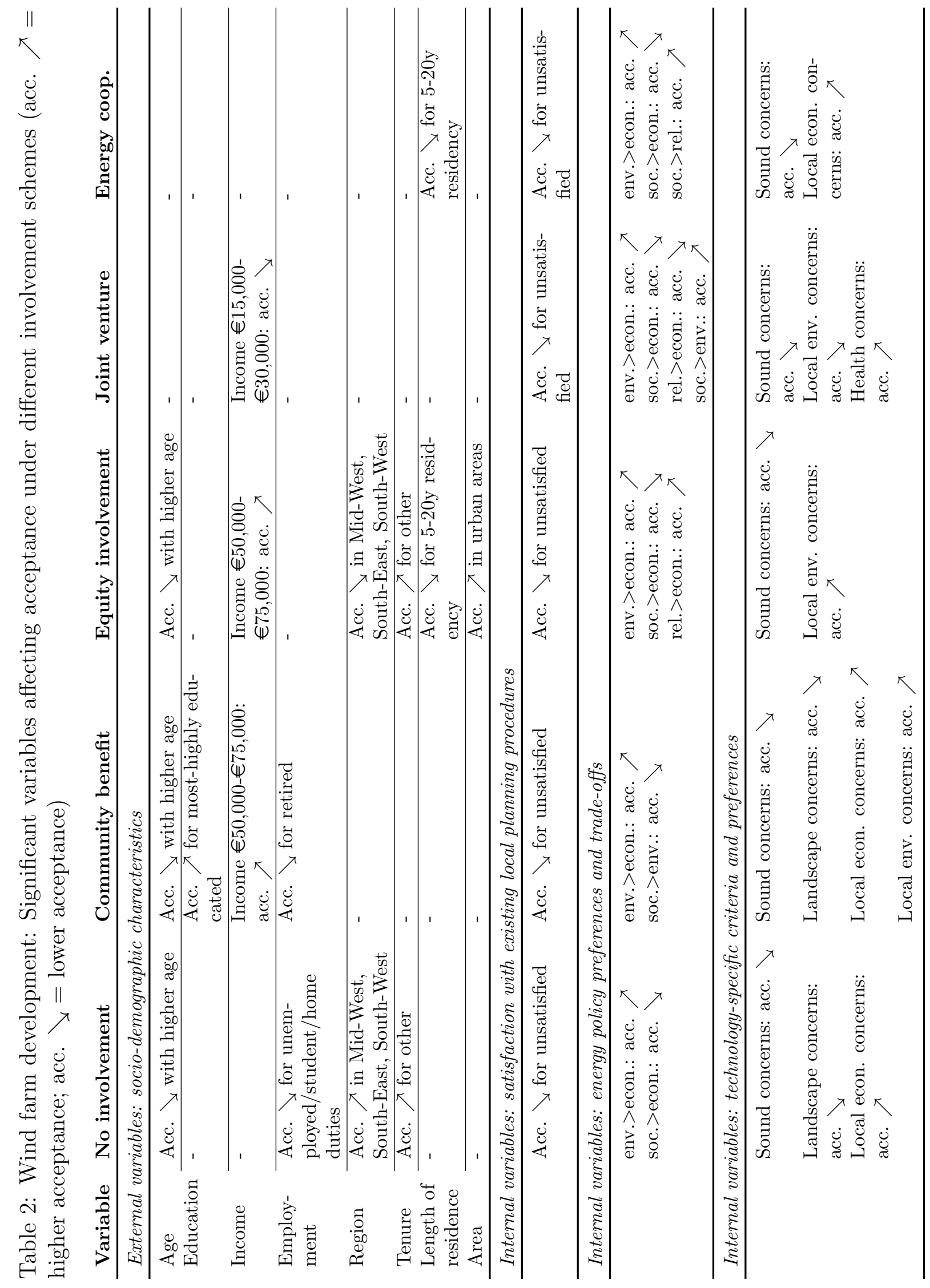




\subsubsection{Willingness to accept wind farm development}

When we look at the variables that significantly predict people's willingness to accept wind farm development, we find some similarities across several involvement schemes. Table 2 summarises the findings, while the details of our econometric analysis are provided in Tables 5-9 in Appendix B. Concerning the external (i.e., socio-demographic) variables, age is generally significant (with the exception of energy cooperatives and joint ventures) - relative to those in the youngest age category, older respondents are less likely to accept local wind farm constructions. Income also turns out to be significantly associated with acceptance under different schemes. While households on higher incomes (€50,000 - €75,000) are relatively more willing to accept wind farm development under community benefit schemes and equity involvement, households in the income category $€ 15,000$ $€ 30,000$ are relatively less likely to accept wind developments under joint ventures than those in the lowest income category.

Looking at the internal variables that are consistently associated with acceptance, we find that the satisfaction with local planning procedures is highly significant in determining people's acceptance of wind developments under all schemes. As expected, those who are unsatisfied are significantly more likely to be unwilling to accept a wind farm. From the pairwise trade-offs that people make between the national energy policy objectives (economic competitiveness, environmental sustainability, reliability of supply and social acceptance/impact), we find that people who rank environmental sustainability higher than economic competitiveness (indicated by "env. > econ." in Table 2) are significantly more likely to accept a wind farm across all involvement schemes. Among the technology-specific criteria, people who are concerned about sound impacts of wind farms are consistently less likely to accept their construction under all schemes.

Concerning further external variables that are significantly associated with acceptance in the absence of any form of involvement, we find that a person's employment status is generally significantly related to their acceptance of wind farm development; relative to those in full-time employment, people in the unemployed/student/home duties/other category show a lower level of acceptance of wind farm development. Moreover, we find that people living in the Mid-West, South-West or South-East are more likely to accept the development of a wind farm. This region has seen a relatively high level of wind farm development in the past and there is evidence that acceptance increases with increased exposure to wind energy (Wolsink, 2007). Also, relative to owner-occupiers, those with "other" categories of tenure show a greater willingness to accept wind farm development (see Table 2, for further details see Table 5); perhaps indicating that they are less concerned with long-term implications, or declining property values. Looking at internal variables, we find that from the technology-specific criteria, people who are concerned about the visual impacts of wind farms on the landscape are less likely to accept their construction, while 
people who consider wind farms to have positive effects on the local economy are more likely to accept them.

When we turn to further drivers of acceptance of wind farm development in the case of involvement via a community benefit scheme $(C B S)$, we find that a different set of external (sociodemographic) variables is associated with acceptance levels than in the absence of any involvement scheme. The significant internal variables, however, are similar (see Table 2). Under a CBS, education is a significant predictor of acceptance. Those with the highest education level are relatively more willing to accept wind farms. Retired people, however are more likely to express an unwillingness to accept a wind farm than people in employment. Looking at further internal variables, we find that people who place a relatively higher weight on social acceptance than on environmental concerns are less likely to express acceptance. In terms of the technology-specific criteria, we find that people who are concerned about landscape impacts of wind farms are less likely to accept their development, while people who perceive positive local environmental and economic effects are more likely to accept.

Considering further external variables associated with acceptance levels of local wind farms under equity involvement, we find that people living in the Mid-West, South-West and South-East are less likely to accept local wind farm developments when they would be compensated with an equity stake in the project. Moreover, people in other categories of tenure and people in urban areas are more likely to accept, while people who have been living in their residence for relatively longer are less likely to accept a wind farm under equity involvement. Looking at further internal variables, we find that people who put a higher weight on supply reliability than economics are more likely to express willingness to accept. In terms of the technology-specific criteria, the possibility of positive effects on the local environment increase acceptance.

Looking at what variables predict wind acceptance under joint ventures, we find no further external variables to be significant. In terms of additional internal variables, we find that the tradeoffs between supply reliability and economics, and between social acceptance and environmental concerns are significant predictors. Furthermore, the perceived local environmental impacts and health concerns are significantly associated with acceptance under joint ventures.

Regarding additional external variables that are associated with people's acceptance when communities are involved in an energy cooperative, it appears that only length of residence is a significant predictor. When turning to further internal variables, however, we find that the tradeoff between social impact and supply reliability is a predictor of people's acceptance. We also find that the perceived local economic impact affects people's acceptance under this scheme (see Table $2)$. 


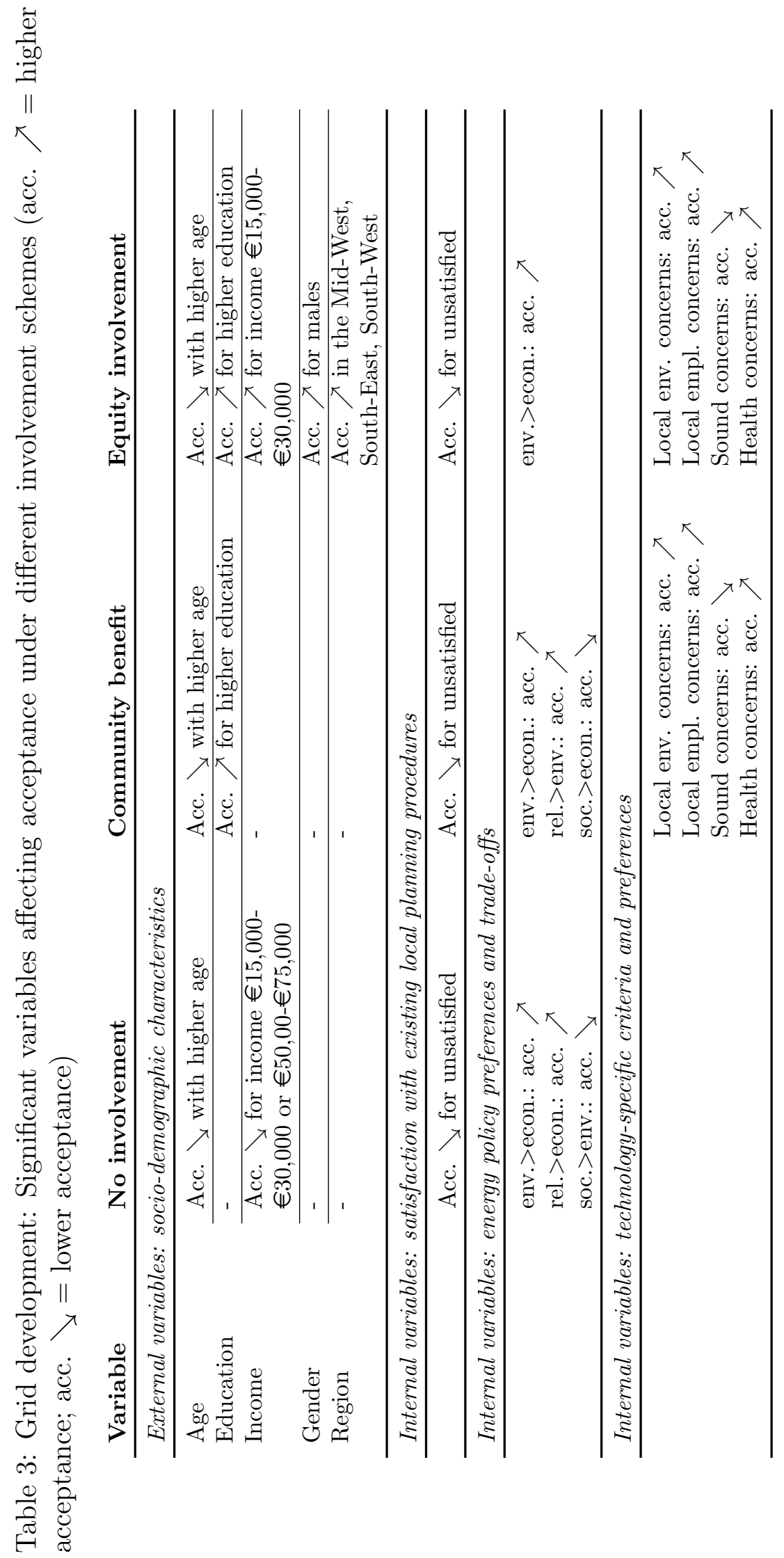




\subsubsection{Willingness to accept transmission grid development}

Next we turn to the characteristics that are significant predictors of acceptance of local transmission grid development under different involvement schemes, which are fewer in the case of the grid. Table 3 summarises our results, while all details are provided in Tables 10-12 in Appendix B. As discussed in section 4.1, acceptance levels of transmission grid development are generally lower than for wind, which is particularly true in the case of acceptance without any form of involvement. Table 3 shows that relatively few of the external variables which we consider are significantly associated with these acceptance levels. Among the external variables, age decreases acceptance for all schemes. Looking at the internal variables, the satisfaction with local planning procedures significantly predicts acceptance across all schemes - those that are unsatisfied are less likely to express willingness to accept grid development. In terms of the environmental-economic trade-off, those that ascribe a higher importance to environmental sustainability are more likely to accept grid development.

Looking at further variables that are associated with grid acceptance under individual schemes, we find that, if no involvement scheme is offered, people in income categories $€ 15,000$ - $€ 30,000$ and $€ 50,000$ - $€ 75,000$ are significantly less likely to accept grid development. The other sociodemographic characteristics, however, do not significantly predict acceptance in the absence of community involvement.

Further internal variables that affect acceptance of grid development in the absence of community involvement are trade-offs between supply reliability and economics, as well as between social impacts and environmental sustainability. Interestingly, the perceptions of technology-specific criteria are not significant in this case.

Turning to external variables (beyond age) that affect the acceptance of grid developments under a $C B S$, we find that acceptance increases for those that have higher education levels. Other socio-demographic variables do not play a role in driving people's acceptance. Further significant internal variables (beyond satisfaction and the environmental-economic trade-off) under this scheme include the trade-offs between supply reliability and the environment as well as between social acceptance and economic considerations. Furthermore, looking at the technology-specific criteria, we find that those who perceive that grid developments have a positive impact on the local environment and employment, as well as on health, are more likely to accept such developments. Those that are concerned about the impact on sound, however, are less likely to accept grid developments.

In terms of further external variables driving grid acceptance under equity involvement, we find again that people with higher levels of education are more likely to be willing to accept local grid constructions under this scheme. Moreover, people in the income bracket $€ 15,000$ - $€ 30,000$, 
males, and people living in the Mid-West, South-West or South-East are more likely to accept grid development under equity involvement. Further internal variables that play a role include technology-specific criteria. The patterns are exactly the same as under the CBS.

\subsubsection{How various involvement schemes can increase acceptance}

In addition to examining the variables associated with overall acceptance rates, we also look at the factors that are associated with an increase in acceptance under each of the involvement schemes, compared to the situation where no involvement is offered. As described in section 3.2.2, we use a logit model for this analysis. Once again we look at the significance of external and internal factors associated with increased acceptance. The full results are displayed in Tables 13 and 14 of Appendix B. A summary of findings is presented in Table 4 a) and b).

We first analyse the increased acceptance under different involvement schemes for wind farms. Of the external variables that predict the likelihood of increased acceptance under each scheme (see Table 4 a)), we find that they generally differ from those that predict levels of acceptance. Income is never statistically significant, and age and employment only predict increased acceptance under energy cooperatives or joint ventures. Older people, and people in unemployment, home duties or students are more likely to expressed increased acceptance of wind farm development under these schemes than in the case where no involvement is offered. We also find that among the external variables, level of education predicts increased acceptance across all involvement schemes. Interestingly, however, only those respondents with the highest levels of formal education are more likely to express increased acceptance of wind farms when any involvement scheme is in place. Another interesting finding is that renters are less likely to show an increased acceptance when compensation is offered via equity involvement or energy cooperatives. Renters are often reported to be more likely to accept infrastructure developments since they might not feel the same level of

impact and may be less concerned about property values (e.g., Bertsch et al., 2017). Our finding for the increased acceptance under these involvement schemes, however, seems to indicate that renters might feel that they cannot participate in the benefit sharing in the same way as home owners. 


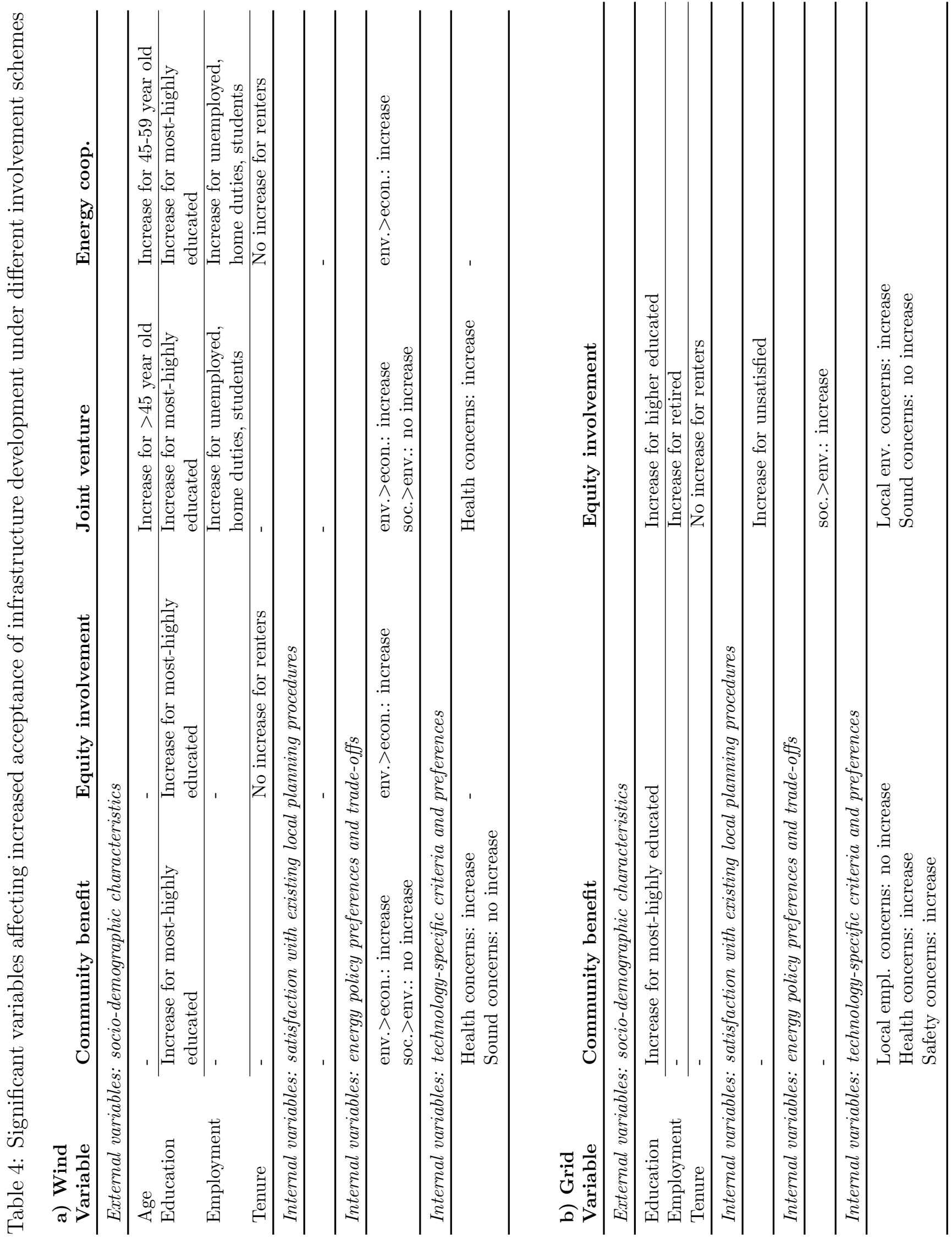


Turning next to the internal variables that predict increased acceptance for wind farm developments, we find that the satisfaction with local planning procedures is not significant; this is surprising as it was highly significant in driving people's acceptance levels. Contrariwise, the environmental-economic trade-off - another variable significantly associated with acceptance across all schemes, also turns out to be a significant predictor of increased acceptance under all schemes. Other significant, internal variables include the social-environmental trade-off as well as health concerns under community benefit schemes and joint ventures. Moreover, sound concerns are found to be significant for a CBS.

Our final set of results concerns the variables associated with increased acceptance of grid development under the two proposed involvement schemes (see Table $4 \mathrm{~b}$ )). Comparing the results on the "external" variables to those of increased wind acceptance, we find that almost all the same variables are associated with increased acceptance of grid development under the proposed schemes - particularly under equity involvement. As for wind, those with the highest levels of formal education are likely to express increased acceptance under either of the considered schemes, relative to a situation of no involvement. Moreover, if offered an equity stake in the project, retired people are more likely, while renters are less likely, to show increased acceptance. An exception to the similarities with wind is that age is never a significant predictor of increased acceptance in the case of grid development.

When looking at the internal variables, we find that, as opposed to wind, satisfaction with local planning procedures predicts increased acceptance of grid development under equity involvement. However, turning to the national energy policy preferences, the only variable that shows a weak significance is the social-environmental trade-off under equity involvement. In terms of the technology-specific criteria, we find that health and safety concerns, as well as perceived local employment effects, are associated with increased acceptance under a CBS, while perceived impact on the local environment and sound predict increased acceptance under equity involvement.

\section{Discussion}

While some studies of community involvement schemes indicate that acceptance increases with deeper levels of engagement (e.g., Warren and McFadyen (2010) for Scotland or Ek and Persson (2014) for Sweden), we find that Irish citizens do not have a preference for schemes involving deeper levels of community involvement. There are different possible explanations for our observations. To begin with, we use stated preferences for hypothetical infrastructure developments from a nationally representative sample. Our analysis shows that no single involvement scheme fits all preferences but that different groups in the population prefer different schemes. Our results 
contrast with those of Warren and McFadyen (2010), who analyse attitudes towards existing wind farms in two Scottish communities. They find that attitudes in the community that owns the wind farm are more positive than in the community with a developer-owned wind farm, suggesting a preference for deeper levels of involvement. However, this does not necessarily contradict our findings since (a) we cannot conclude that people in all Scottish communities have the same preferences and (b) there are also groups within the Irish population that prefer deeper levels of involvement.

Our findings may also reflect potential risk aversion among respondents, or may be related to perceptions of justice/injustice and concerns about the distribution of costs and benefits between developers and communities (e.g., in the case of a joint venture) or within communities (e.g., in the case of an energy cooperative). Indeed, previous research has shown that perceived injustice can affect people's acceptance levels (Gross, 2007; Aitken, 2010; Goedkoop and Devine-Wright, 2016). Huijts et al. (2012) distinguish between two dimensions of justice: distributional justice (perceived fairness of the distribution of costs, risks and benefits) and procedural justice (perceived fairness of the decision and planning processes). Regarding the role of these two dimensions, there is evidence from the literature that being involved in the planning process (e.g., through a community representative - related to aspects of procedural justice) seems to be at least as important for communities as concerns about distributional justice, see Cowell et al. (2011) and Brennan and Van Rensburg (2016) for wind in Wales and Ireland respectively and Devine-Wright and Batel (2013) and Cohen et al. (2016) for grid development in the UK and the EU-27 respectively. This may be driven by aspects of trust, which is closely interrelated with perceptions of justice (Huijts et al., 2012). Thus, if there is a lack of trust (either within a community or between a community and a developer), this may lead to perceived injustice and therefore lower levels of acceptance for infrastructure development under involvement schemes with deeper levels of involvement.

Our results do confirm some pervious analyses specific to the Irish context. While the study by SEI (2003) did not distinguish between different involvement schemes, they did ask Irish citizens whether they would be interested in investing in a local wind farm, and only $14 \%$ expressed some level of interest. The study by Brennan et al. (2017) using focus groups in Ireland reports that the majority of residents consider a discount on their electricity bill as the best form of compensation for wind farm development. This low appetite for personal financial involvement is in line with our findings. Whether this lack of appetite for deeper involvement is driven by risk aversion, or by a lack of trust, it suggests that if policy makers are to adopt one of these involvement mechanisms, time and resources must first be invested in informing local communities of the way in which they will be compensated or involved, and ensuring that these mechanisms are perceived as fair.

In terms of which schemes may lead to an increase in acceptance, one particularly notable finding is the large number of respondents for whom acceptance levels do not change when various 
involvement schemes are proposed. This suggests that a significant proportion of the population are ideologically either opposed to or in favour of wind farm or grid development, and offering some form of compensation or project ownership does not change this. This highlights a particular policy challenge in terms of changing acceptance levels amongst those who are opposed to these developments.

Considering the econometric analyses of infrastructure acceptance, of the socio-demographic variables, we find that age is generally the most consistently significant predictor of acceptance, with older people generally less willing to accept local infrastructure development under most involvement schemes. In terms of the attitudinal variables, we find that people who are unhappy with current local planning procedures are always less accepting of development projects. We also find that people who place a higher importance on environmental as opposed to economic objectives, in terms of national energy policy, are more willing to accept wind farm and grid development under all proposed involvement schemes, which concurs with what Dietz et al. (1998) report for their analysis of the U.S. General Social Survey (GSS) environment module. In general, greater importance placed on social impact, relative to economic concerns, is associated with lower acceptance levels in our analysis. In terms of the technology-specific criteria, concerns regarding sound reduce acceptance levels, whereas local (different from national) economic concerns are associated with higher levels of acceptance.

A surprising result we uncover is that, when looking at the internal variables that are associated with increased acceptance, we find that the satisfaction with local planning procedures is generally not significant. This is somewhat unexpected given that the schemes would imply a change to existing planning procedures in a way that, one would hope, should lead to an increased acceptance. In terms of further internal variables, however, we find that acceptance of wind farm developments increases for those who place a higher importance on environmental relative to economic considerations - similar to the results on overall acceptance levels. In terms of the perceived technology-specific impacts, concerns regarding the health impacts of infrastructure development appear to be the most consistent predictor of increased acceptance.

Critically reflecting upon our findings, we wish to acknowledge that our results need to be interpreted with some caution. As with many empirical analyses, our estimates may suffer from bias. One potential source of bias is the use of a stated preference approach; while we do not believe that people have an incentive to be untruthful in our questionnaire, we cannot guarantee that people's responses to our questions provide an exact representation of what they would do in practice. Furthermore, we have conducted our questionnaire using an internet panel; while we cannot guarantee that the sub-sample of the population on this panel are representative of the population, we have sought to ensure that the panel is fully representative of those groups of people who may be under-represented on an internet panel (such as, for example, older people). 
Our efforts to ensure representativeness in this regard should minimise this source of bias. Another limitation of our analysis is that, while it sheds light on people's overall acceptance of technology development under various involvement schemes, it does not reveal the extent to which people would wish to be compensated. Moreover, while our models analysing acceptance under different involvement mechanisms for wind and grid development revealed many significant variables, the models for analysing how acceptance increases under different schemes are weaker. This suggests that relevant variables may not have been captured in our analysis. For instance, a number of further factors have been discussed in the literature in terms of their influence on public acceptance of energy infrastructure. This includes the role of place attachment, which was found to be a significant predictor of acceptance (Vorkinn and Riese, 2001; Devine-Wright, 2012; Bidwell, 2013). However, most research focusses on a single technology and, since our focus was to analyse wind as well as grid developments - both of which play a role in the transition to a low carbon energy system, there was limited scope to analyse a yet larger variety of explanatory variables. However, exploring the role of further (particularly internal) predictors is an important topic for future research.

\section{Conclusions}

In this paper we have analysed the important topic of willingness to accept local infrastructure development (specifically wind and grid development projects) when the local community is not involved, and under a range of potential involvement mechanisms. Given that Ireland, along with other EU countries, is subject to time-constrained, binding RES-E targets, this topic is of major importance in the transition towards a more environmentally-friendly electricity generation system. Finding ways of minimising local objections is needed to expedite necessary developments and meet binding targets.

In order to gain important insights into the views of Irish citizens vis-à-vis hypothetical expansion of wind farms and the transmission grid, we conducted a nationally-representative survey. In addition to collecting detailed socio-demographic and attitudinal information, we also asked participants about their willingness to accept local developments under a range of community involvement schemes, which varied by their depth of involvement. The survey results show that acceptance of infrastructure development is highest when communities would be compensated via a community benefit scheme, involving cash transfers but no share in ownership or associated project risk. In terms of how involvement may increase acceptance, two particularly notable results that emerged are that, firstly, it is involvement schemes with lower levels of community engagement that increase acceptance the most - indicating a degree of overall risk aversion amongst citizens, or an 
unwillingness to accept compensation in a form with which people are unfamiliar. And, secondly, for a large proportion of respondents (42-43\%), their acceptance of infrastructure developments does not change when they are offered compensation/involvement, indicating that they are either ideologically opposed to, or in favour of, such developments. The results of our econometric analysis show that a person's age is often a significant predictor of their technology acceptance level, as is their level of satisfaction with status-quo planning procedures and the relative weight they place on environmental concerns.

Our findings may be of use for policy formation in a number of ways. If policy makers hope to increase local infrastructure acceptance levels via community involvement, our results shed light on which schemes would lead to the greatest increase in acceptance. In this regard, our findings are not always consistent with previous analyses from other countries - cautioning policy-makers to refrain from assuming that the findings from other countries can universally be applied. Furthermore, our results showing that for a large proportion of respondents (more that 40\%) acceptance levels do not change when compensation/involvement is offered for hypothetical development indicate that policy-makers may need to do more to address the fundamental concerns of citizens, rather than merely offering compensation/involvement, if acceptance levels are to be increased. Our econometric analysis indicates which socio-demographic characteristics and attitudinal factors significantly predict and increase acceptance levels for both wind farms and grid development, under each of the involvement schemes considered. These results indicate which groups of society may require the most convincing on the necessity of RES-E infrastructure development. Moreover, the results on attitudinal variables suggest which aspects and characteristics of the infrastructure should be highlighted when communicating project development plans to the public, and have important implications for the ways in which policy makers outline the rationale behind infrastructure projects and target information campaigns.

For those citizens who oppose local infrastructure development under each of the proposed involvement schemes, it would be useful to know what, if anything, would increase their acceptance levels. Future work in this area should build upon our current study to advance this research and the associated policy questions.

\section{References}

Aitken, Mhairi (2010) 'Why we still dont understand the social aspects of wind power: A critique of key assumptions within the literature.' Energy Policy 38(4), 1834-1841

Anton, Charis E, and Carmen Lawrence (2014) 'Home is where the heart is: The effect of place 
of residence on place attachment and community participation.' Journal of Environmental Psychology 40, 451-461

Battaglini, Antonella, Nadejda Komendantova, Patricia Brtnik, and Anthony Patt (2012) 'Perception of barriers for expansion of electricity grids in the European Union.' Energy Policy $47,254-259$

Bauwens, Thomas, Boris Gotchev, and Lars Holstenkamp (2016) 'What drives the development of community energy in Europe? The case of wind power cooperatives.' Energy Research E6 Social Science 13, 136-147

Beddoe, Marcus, and Andrew Chamberlin (2003) 'Avoiding confrontation: securing planning permission for on-shore wind energy developments in England: comments from a wind energy developer.' Planning Practice \& Research 18(1), 3-17

Bell, Derek, Tim Gray, and Claire Haggett (2005) 'The social gapin wind farm siting decisions: explanations and policy responses.' Environmental Politics 14(4), 460-477

Ben-Akiva, Moshe, Mark Bradley, Takayuki Morikawa, Julian Benjamin, Thomas Novak, Harmen Oppewal, and Vithala Rao (1994) 'Combining revealed and stated preferences data.' Marketing Letters 5(4), 335-349

Bertsch, Valentin, Margeret Hall, Christof Weinhardt, and Wolf Fichtner (2016) 'Public acceptance and preferences related to renewable energy and grid expansion policy: Empirical insights for Germany.' Energy 114, 465-477

Bertsch, Valentin, Marie Hyland, and Michael Mahony (2017) 'What drives people's opinions of electricity infrastructure? empirical evidence from Ireland.' Energy Policy 106, 472-497

Bidwell, David (2013) 'The role of values in public beliefs and attitudes towards commercial wind energy.' Energy Policy 58, 189-199

Brennan, Noreen, and Thomas M Van Rensburg (2016) 'Wind farm externalities and public preferences for community consultation in Ireland: A discrete choice experiments approach.' Energy Policy 94, 355-365

Brennan, Noreen, Thomas M Van Rensburg, and Cyril Morris (2017) 'Public acceptance of largescale wind energy generation for export from Ireland to the UK: evidence from Ireland.' Journal of Environmental Planning and Management pp. 1-26 
Burningham, Kate (2000) 'Using the language of NIMBY: a topic for research, not an activity for researchers.' Local Environment 5(1), 55-67

Carson, Richard T, and Jordan J Louviere (2011) 'A common nomenclature for stated preference elicitation approaches.' Environmental and Resource Economics 49(4), 539-559

Chernozhukov, Victor, Ivan Fernandez-Val, Jinyong Hahn, and Whitney Newey (2009) 'Identification and estimation of marginal effects in nonlinear panel models.' CeMMAP working papers CWP05/09, Centre for Microdata Methods and Practice, Institute for Fiscal Studies, March

Ciupuliga, AR, and E Cuppen (2013) 'The role of dialogue in fostering acceptance of transmission lines: the case of a France-Spain interconnection project.' Energy Policy 60, 224-233

Cohen, Jed, Klaus Moeltner, Johannes Reichl, and Michael Schmidthaler (2016) 'An empirical analysis of local opposition to new transmission lines across the EU-27.' The Energy Journal

Cotton, Matthew, and Patrick Devine-Wright (2011) 'Discourses of energy infrastructure development: a Q-method study of electricity transmission line siting in the UK.' Environment and Planning A 43(4), 942-960

Cowell, Richard, Gill Bristow, and Max Munday (2011) 'Acceptance, acceptability and environmental justice: the role of community benefits in wind energy development.' Journal of Environmental Planning and Management 54(4), 539-557

Devine-Wright, Patrick (2005) 'Beyond nimbyism: towards an integrated framework for understanding public perceptions of wind energy.' Wind Energy 8(2), 125-139

_ (2011) 'Place attachment and public acceptance of renewable energy: A tidal energy case study.' Journal of Environmental Psychology 31(4), 336-343

_ (2012) 'Explaining nimby objections to a power line: the role of personal, place attachment and project-related factors.' Environment and Behavior p. 0013916512440435

Devine-Wright, Patrick, and Susana Batel (2013) 'Explaining public preferences for high voltage pylon designs: An empirical study of perceived fit in a rural landscape.' Land Use Policy 31, 640649

Devine-Wright, Patrick, Susana Batel, Oystein Aas, Benjamin Sovacool, Michael Carnegie LaBelle, and Audun Ruud (2017) 'A conceptual framework for understanding the social acceptance of energy infrastructure: Insights from energy storage.' Energy Policy 107, 27-31 
Dietz, Thomas, Paul C Stern, and Gregory A Guagnano (1998) 'Social structural and social psychological bases of environmental concern.' Environment and Behavior 30(4), 450-471

Edwards, W, and D Von Winterfeldt (1986) 'Decision analysis and behavioral research'

Edwards, Ward (1977) 'How to use multiattribute utility measurement for social decision making.' IEEE Transactions on Systems, Man, and Cybernetics 7(5), 326-340

Ek, Kristina, and Lars Persson (2014) 'Wind farmswhere and how to place them? a choice experiment approach to measure consumer preferences for characteristics of wind farm establishments in Sweden.' Ecological economics 105, 193-203

Furby, Lita, Paul Slovic, Baruch Fischhoff, and Robin Gregory (1988) 'Public perceptions of electric power transmission lines.' Journal of Environmental Psychology 8(1), 19-43

Galesic, Mirta, and Michael Bosnjak (2009) 'Effects of questionnaire length on participation and indicators of response quality in a web survey.' Public Opinion Quarterly 73(2), 349-360

Goedkoop, Fleur, and Patrick Devine-Wright (2016) 'Partnership or placation? the role of trust and justice in the shared ownership of renewable energy projects.' Energy Research ES Social Science 17, 135-146

Gross, Catherine (2007) 'Community perspectives of wind energy in Australia: The application of a justice and community fairness framework to increase social acceptance.' Energy Policy $35(5), 2727-2736$

Guagnano, Gregory A, Paul C Stern, and Thomas Dietz (1995) 'Influences on attitude-behavior relationships a natural experiment with curbside recycling.' Environment and Behavior 27(5), 699718

Guo, Yue, Peng Ru, Jun Su, and Laura Diaz Anadon (2015) 'Not in my backyard, but not far away from me: Local acceptance of wind power in China.' Energy 82, 722-733

Hobman, EV, P Ashworth, P Graham, and J Hayward (2012) 'The Australian publics preferences for energy sources and related technologies.' Pullenvale: CSIRO

Huijts, Nicole MA, Eric JE Molin, and Linda Steg (2012) 'Psychological factors influencing sustainable energy technology acceptance: A review-based comprehensive framework.' Renewable and Sustainable Energy Reviews 16(1), 525-531

Jobert, Arthur, Pia Laborgne, and Solveig Mimler (2007) 'Local acceptance of wind energy: Factors of success identified in french and german case studies.' Energy Policy 35(5), 2751-2760 
Kim, Soo-Min, Patrick Pantel, Tim Chklovski, and Marco Pennacchiotti (2006) 'Automatically assessing review helpfulness.' In 'Proceedings of the 2006 Conference on empirical methods in natural language processing' Association for Computational Linguistics pp. 423-430

Kułakowski, Konrad (2015) 'Notes on order preservation and consistency in AHP.' European Journal of Operational Research 245(1), 333-337

Long, J Scott, and Jeremy Freese (2006) Regression models for categorical dependent variables using Stata (Stata press)

Musall, Fabian David, and Onno Kuik (2011) 'Local acceptance of renewable energya case study from southeast Germany.' Energy Policy 39(6), 3252-3260

National Economic and Social Council (2014) Wind Energy in Ireland: Building Community Engagement and Social Support (An Oifig Naísiuńta um Fhorbairt Eacnamióch agus Shoísialta= National Economic \& Social Development Office)

Pearce, David (2002) 'An intellectual history of environmental economics.' Annual Review of Energy and the Environment 27(1), 57-81

Peterson, Bercedis, and Frank E Harrell Jr (1990) 'Partial proportional odds models for ordinal response variables.' Applied Statistics pp. 205-217

Podsakoff, Philip M, Scott B MacKenzie, Jeong-Yeon Lee, and Nathan P Podsakoff (2003) 'Common method biases in behavioral research: a critical review of the literature and recommended remedies.' Journal of Applied Psychology 88(5), 879

Poortinga, Wouter, Nick Pidgeon, Irene Lorenzoni et al. (2006) 'Public perceptions of nuclear power, climate change and energy options in Britain: summary findings of a survey conducted during October and November 2005.' Technical Report (Understanding Risk Working Paper 06-02). Norwich: Centre for Environmental Risk

Populus (2005) 'Energy balance of power poll.' http://www.populus.co.uk/poll/energy-balance-ofpower/

Rand, Joseph, and Ben Hoen (2017) 'Thirty years of north american wind energy acceptance research: What have we learned?' Energy Research \& Social Science 29, 135-148

Raven, RPJM, RM Mourik, CFJ Feenstra, and E Heiskanen (2009) 'Modulating societal acceptance in new energy projects: towards a toolkit methodology for project managers.' Energy 34(5), 564574 
Saaty, Thomas L (1980) The analytic hierarchy process (New York: McGraw-Hill New York)

Schreuer, Anna (2016) 'The establishment of citizen power plants in Austria: A process of empowerment?' Energy Research \& Social Science 13, 126-135

SEI (2003) 'Attitudes towards the development of wind farms in Ireland.' Sustainable Energy Ireland

Sills, Stephen J, and Chunyan Song (2002) 'Innovations in survey research an application of webbased surveys.' Social Science Computer Review 20(1), 22-30

Soini, Katriina, Eija Pouta, Maija Salmiovirta, Marja Uusitalo, and Tapani Kivinen (2011) 'Local residents perceptions of energy landscape: the case of transmission lines.' Land Use Policy 28(1), 294-305

Stern, Paul C, Thomas Dietz, and Gregory A Guagnano (1995) 'The new ecological paradigm in social-psychological context.' Environment and Behavior 27(6), 723-743

Terwel, Bart W, Fieke Harinck, Naomi Ellemers, and Dancker DL Daamen (2011) 'Going beyond the properties of $\mathrm{CO} 2$ capture and storage (CCS) technology: how trust in stakeholders affects public acceptance of CCS.' International Journal of Greenhouse Gas Control 5(2), 181-188

Toke, Dave (2005) 'Community wind power in Europe and in the UK.' Wind Engineering $29(3), 301-308$

Van der Horst, Dan (2007) 'NIMBY or not? exploring the relevance of location and the politics of voiced opinions in renewable energy siting controversies.' Energy Policy 35(5), 2705-2714

Van Rensburg, Thomas M, Hugh Kelley, and Nadine Jeserich (2015) 'What influences the probability of wind farm planning approval: Evidence from Ireland.' Ecological Economics 111, 12-22

Vorkinn, Marit, and Hanne Riese (2001) 'Environmental concern in a local context: The significance of place attachment.' Environment and Behavior 33(2), 249-263

Walker, Chad, and Jamie Baxter (2017) 'Procedural justice in canadian wind energy development: A comparison of community-based and technocratic siting processes.' Energy Research Ef Social Science 29, 160-169

Walker, Gordon, and Patrick Devine-Wright (2008) 'Community renewable energy: What should it mean?' Energy Policy 36(2), 497-500 
Warren, Charles R, and Malcolm McFadyen (2010) 'Does community ownership affect public attitudes to wind energy? a case study from south-west Scotland.' Land Use Policy 27(2), 204213

Williams, Richard (2006) 'Generalized ordered logit/partial proportional odds models for ordinal dependent variables.' Stata Journal 6(1), 58

Williams, Richard et al. (2006) 'Generalized ordered logit/partial proportional odds models for ordinal dependent variables.' Stata Journal 6(1), 58

Wolsink, Maarten (2000) 'Wind power and the nimby-myth: institutional capacity and the limited significance of public support.' Renewable Energy 21(1), 49-64

_ (2007) 'Wind power implementation: the nature of public attitudes: equity and fairness instead of backyard motives.' Renewable and Sustainable Energy Reviews 11(6), 1188-1207

Wüstenhagen, Rolf, Maarten Wolsink, and Mary Jean Bürer (2007) 'Social acceptance of renewable energy innovation: An introduction to the concept.' Energy Policy 35(5), 2683-2691

Zarnikau, Jay (2003) 'Consumer demand for green powerand energy efficiency.' Energy Policy $31(15), 1661-1672$

Zoellner, Jan, Petra Schweizer-Ries, and Christin Wemheuer (2008) 'Public acceptance of renewable energies: Results from case studies in Germany.' Energy Policy 36(11), 4136-4141 


\section{A Survey structure and questions}

\section{Category 1: Community involvement schemes}

Question block no.

Question text
1.1

Involvement in wind farm development: When new wind farms are developed local communities may be affected. We now ask for your opinion regarding the possible processes that could be put in place to compensate and involve the residents of the local communities. There are a number of potential methods that could be used to allow local communities to share the financial benefits, as well as the associated risks and costs, of wind farm developments. Here we consider four potential involvement schemes. How willing would you be to accept a new wind farm in your local community if either none or one of these profit sharing schemes were in place?

Technologies to consider Wind turbines

Involvement mechanisms for No profit sharing scheme, Community benefit scheme, Equity involvement, consideration Joint venture, Energy Cooperative (see section 2.2)

Scale of possible answers 1: unwilling, 2: somewhat unwilling, 3: neutral, 4: somewhat willing, 5: willing, 6: don't know

Question block no.

Question text

Technologies to consider

Involvement mechanisms for consideration

1.2

Involvement in grid development: As is the case for new wind farms, when the electrical transmission grid (the "wires") is expanded local communities may be affected. We now ask for your opinion regarding the possible processes that could be put in place to compensate local communities. As with new wind farms, schemes could be put in place to allow local communities to share in the benefits of expanding the transmission grid. However, due to the technical nature of grid operations, the potential mechanisms of community involvement are likely to be fewer. Here we consider two potential involvement schemes. How willing would you be to accept a new transmission line in your community if none or one of these profit sharing schemes were in place?

Above ground electrical transmission line expansion

No profit sharing scheme, Community benefit scheme, Equity involvement (see section 2.2)

1: unwilling, 2: somewhat unwilling, 3: neutral, 4: somewhat willing, 5: willing, 6: don't know 
Question block no. 2

Question text

In which region do you live?

Next please indicate the area you

live in.

How long have you been living in this area?

What is your gender?

How old are you?

Is the dwelling in which you live...?

What is the highest level of education or training you have attained?

At the moment are you ...?

Can you state which of the following categories best represents your household's yearly income before tax?
Scale of possible answers

1: Border, 2: Midland, 3: West, 4: Dublin, 5: Mid-East, 6: Mid-West, 7: South-East, 8: South-West

County/City/Dublin area within the above region

1: Less than one year, 2: 1-5 years, 3: 6-10 years, 4: 11-20 years, 5: More than 20 years

1: Female, 2: Male

1: 15-19 years, 2: 20-24 years, 3: 25-34 years, 4: 35-44 years, 5: 45-54 years, 6: 55-59 years, 7: 60-64 years, 8: 65 years or older

1: Owneroccupied, 2: Owneroccupied having being purchased through a local authority scheme, 3: Being rented (owner not in residence in this household), 4: Not owned by occupant(s) and being occupied rent free, 5: Not owned by occupant(s) and rent free to some member(s) of the household only, 6: Owner occupied and rented out to some member(s) of the household, 7: Other (please specify)

1: Primary school, pre-primary or no formal education, 2: Secondary 1 (Junior/Inter Certificate), 3: Secondary 2 (Leaving Certificate), 4: Postsecondary non-tertiary (e.g. Technical or vocational qualification, Advanced certificate or Higher certificate), 5: Third level non-honours degree (e.g. National Diploma (HETAC/NCEA), Bachelor Degree (DIT), Diploma in Police Studies, 3 year Diploma or Ordinary Bachelor Degree at NFQ level 7), 6: Third level honours degree or higher, 7: Other (please specify)

1: At work, 2: Unemployed, 3: Student, 4: Engaged on home duties, 5: Retired from employment, 6: Other (please specify)

1: Less than 15,000 Euros, 2: 15,000 to 30,000 Euros, 3: 30,000 to 50,000

Euros, 4: 50,000 to 75,000 Euros, 5: 75,000 or more Euros 
Category 3: National energy policy preferences, technology-specific criteria, satisfaction with local planning procedures

\begin{tabular}{|c|c|}
\hline Question block no. & 3.1 \\
\hline Question text & $\begin{array}{l}\text { When planning the future energy system, numerous factors play a crucial role } \\
\text { (for example economic and environmental concerns, the reliability of supply, } \\
\text { and social acceptance). Please state your opinion on the relative importance } \\
\text { of the item pairs listed below. }\end{array}$ \\
\hline Item pairs & $\begin{array}{l}\text { Compared to economic viability, environmental sustainability is ..., } \\
\text { Compared to economic viability, reliability of supply is ..., } \\
\text { Compared to economic viability, social acceptance is ..., } \\
\text { Compared to environm. sustainability, reliability of supply is ..., } \\
\text { Compared to environm. sustainability, social acceptance is ..., } \\
\text { Compared to reliability of supply, social acceptance is ... }\end{array}$ \\
\hline Scale of possible answers & $\begin{array}{l}1: \ldots \text { absolutely more important, } 2: \ldots \text { more important, } 3: \ldots \text { slightly more } \\
\text { important, } 4: \ldots \text { of equal importance, } 5: \ldots \text { slightly less important, } 6: \ldots \text { less } \\
\text { important, } 7: \ldots \text { absolutely less important }\end{array}$ \\
\hline Question block no. & 3.2 \\
\hline Question text & $\begin{array}{l}\text { When assessing different electricity generation and grid expansion options, how } \\
\text { do you rank the following criteria in terms of their importance? }\end{array}$ \\
\hline Criteria to be ranked & $\begin{array}{l}\text { The landscape, Sound, Health, Local environment, Local economy, Local em- } \\
\text { ployment, Air quality, Water quality, Odour, Techn. safety }\end{array}$ \\
\hline Scale of possible answers & 1: unimportant, ..., 5: highly important \\
\hline Question block no. & 3.3 \\
\hline Question text & $\begin{array}{l}\text { Please review each of these technologies in terms of the listed criteria based on } \\
\text { your personal judgement of them, without making comparisons between the } \\
\text { technologies. }\end{array}$ \\
\hline Technologies to judge & Wind turbines, Above-ground electrical transmission line expansion \\
\hline $\begin{array}{l}\text { Criteria for consideration } \\
\text { (technology-dependent) }\end{array}$ & $\begin{array}{l}\text { The landscape, Sound, Health, Local environment, Local economy, Local em- } \\
\text { ployment, Air quality, Water quality, Odour, Techn. safety }\end{array}$ \\
\hline Scale of possible answers & $\begin{array}{l}-2: \text { negative, }-1: \text { somewhat negative, } 0: \text { neutral, } 1: \text { somewhat positive, } 2 \text { : } \\
\text { positive, } 3: \text { No experience or limited knowledge }\end{array}$ \\
\hline Question block no. & 3.4 \\
\hline Question text & $\begin{array}{l}\text { Please indicate how happy you are with the way in which local residents are } \\
\text { currently involved when energy infrastructure is planned to be placed in their } \\
\text { communities. }\end{array}$ \\
\hline Scale of possible answers & $\begin{array}{l}\text { 1: very unsatisfied, } 2 \text { : unsatisfied, } 3 \text { : neutral, } 4 \text { : satisfied, } 5 \text { : very satisfied, } 6 \text { : } \\
\text { don't know }\end{array}$ \\
\hline
\end{tabular}


Screening question no. 1

Question text

The questions in this survey ask for your opinion on various energy-related issues. In order to ensure data quality this question only tests your attention. If you have read this question, please choose the third answer "Question read".

Scale of possible answers $\quad$ 1: Negative influence, 2: Slightly negative influence, 3: Question read, 4: Slightly positive influence, 5: Positive influence

\begin{tabular}{ll}
\hline Screening question no. & $2 \mathrm{a}^{9}$ \\
Question text & How old are you? \\
Scale of possible answers & 1: 15-19 years, 2: 20-24 years, 3: 25-34 years, 4: 35-44 years, 5: 45-54 years, 6: \\
& $55-59$ years, 7: 60-64 years, 8: 65 years or older \\
\hline Screening question no. & $2 \mathrm{~b}^{10}$ \\
Question text & In what year were you born? \\
Scale of possible answers & free text \\
\hline
\end{tabular}

\section{B Additional results}

Tables 5-14 below display the marginal effects and standard errors across all categories of acceptance under each scheme.

\footnotetext{
${ }^{9}$ We check for consistency between respondents' reported age category and their age as calculated from their year of birth. If a respondent placed themselves in an age category that was incorrect, or in one that was not adjacent to the correct category (to allow for minor error), they are not included in our analysis.

${ }^{10}$ See previous footnote.
} 
Table 5: WTA wind-farm development without any involvement

\begin{tabular}{|c|c|c|c|c|c|}
\hline External variables: socio-demographic characteristics & Unwilling & $\begin{array}{c}\text { Somewhat } \\
\text { unwilling }\end{array}$ & Neutral & $\begin{array}{c}\text { Somewhat } \\
\text { willing }\end{array}$ & Willing \\
\hline \multicolumn{6}{|l|}{ Age (reference cat.: Younger than 25) } \\
\hline $25-44$ & $\begin{array}{c}0.0892^{* *} \\
(0.0441)\end{array}$ & $\begin{array}{c}-0.0747^{* *} \\
(0.0321)\end{array}$ & $\begin{array}{c}-5.59 \mathrm{e}-05 \\
(0.0318)\end{array}$ & $\begin{array}{l}0.00242 \\
(0.0305)\end{array}$ & $\begin{array}{l}-0.0169 \\
(0.0174)\end{array}$ \\
\hline $45-59$ & $0.167^{* * *} *$ & $0.0470^{* * *}$ & $-0.0690 * * *$ & $-0.0939 * * *$ & $-0.0513^{* * *}$ \\
\hline 60 or older & $\begin{array}{c}(0.0445) \\
0.212^{* * * *} \\
(0.0590)\end{array}$ & $\begin{array}{c}(0.00891) \\
0.0528^{* * *} \\
(0.00934)\end{array}$ & $\begin{array}{c}(0.0204) \\
-0.0873^{* * *} \\
(0.0260)\end{array}$ & $\begin{array}{c}(0.0212) \\
-0.115^{* * *} \\
(0.0261)\end{array}$ & $\begin{array}{c}(0.0115) \\
-0.0627^{* * *} \\
(0.0145)\end{array}$ \\
\hline \multicolumn{6}{|c|}{ Highest level of education (reference cat.: Primary school) } \\
\hline Leaving certificate & $\begin{array}{c}0.0261 \\
(0.0401)\end{array}$ & $\begin{array}{c}0.0112 \\
(0.0161)\end{array}$ & $\begin{array}{r}-0.00971 \\
(0.0155)\end{array}$ & $\begin{array}{l}-0.0174 \\
(0.0259)\end{array}$ & $\begin{array}{l}-0.0102 \\
(0.0149)\end{array}$ \\
\hline Post-secondary non-tertiary & $\begin{array}{c}0.0367 \\
(0.0425)\end{array}$ & $\begin{array}{c}0.0151 \\
(0.0158)\end{array}$ & $\begin{array}{l}-0.0139 \\
(0.0170)\end{array}$ & $\begin{array}{l}-0.0240 \\
(0.0265)\end{array}$ & $\begin{array}{l}-0.0138 \\
(0.0149)\end{array}$ \\
\hline Third level non-honours degree & $\begin{array}{c}0.0169 \\
(0.0420)\end{array}$ & $\begin{array}{l}0.00730 \\
(0.0173)\end{array}$ & $\begin{array}{c}-0.00623 \\
(0.0160)\end{array}$ & $\begin{array}{l}-0.0113 \\
(0.0275)\end{array}$ & $\begin{array}{r}-0.00661 \\
(0.0158)\end{array}$ \\
\hline Third level honours or above & $\begin{array}{c}0.0232 \\
(0.0437)\end{array}$ & $\begin{array}{c}0.00989 \\
(0.0174)\end{array}$ & $\begin{array}{r}-0.00866 \\
(0.0170)\end{array}$ & $\begin{array}{l}-0.0155 \\
(0.0282)\end{array}$ & $\begin{array}{c}-0.00899 \\
(0.0160)\end{array}$ \\
\hline \multicolumn{6}{|l|}{ Income (reference cat.: Less than 15,000 ) } \\
\hline 15,000 to 30,000 & $\begin{array}{l}-0.0250 \\
(0.0328)\end{array}$ & $\begin{array}{l}-0.0118 \\
(0.0161)\end{array}$ & $\begin{array}{r}0.00865 \\
(0.0110)\end{array}$ & $\begin{array}{c}0.0176 \\
(0.0235)\end{array}$ & $\begin{array}{c}0.0106 \\
(0.0144)\end{array}$ \\
\hline 30,000 to 50,000 & $\begin{array}{c}-0.00634 \\
(0.0358)\end{array}$ & $\begin{array}{c}-0.00292 \\
(0.0167)\end{array}$ & $\begin{array}{l}0.00224 \\
(0.0125)\end{array}$ & $\begin{array}{l}0.00440 \\
(0.0250)\end{array}$ & $\begin{array}{l}0.00262 \\
(0.0150)\end{array}$ \\
\hline 50,000 to 75,000 & $\begin{array}{l}-0.0280 \\
(0.0454)\end{array}$ & $\begin{array}{c}0.0433 \\
(0.0443)\end{array}$ & $\begin{array}{l}-0.0606 \\
(0.0379)\end{array}$ & $\begin{array}{l}0.0777^{*} \\
(0.0457)\end{array}$ & $\begin{array}{l}-0.0324 \\
(0.0209)\end{array}$ \\
\hline 75,000 or more & $\begin{array}{l}0.00367 \\
(0.0479)\end{array}$ & $\begin{array}{c}0.00164 \\
(0.0211)\end{array}$ & $\begin{array}{r}-0.00133 \\
(0.0175)\end{array}$ & $\begin{array}{r}-0.00251 \\
(0.0325)\end{array}$ & $\begin{array}{c}-0.00148 \\
(0.0191)\end{array}$ \\
\hline \multicolumn{6}{|l|}{ Employment (reference cat.: In employment) } \\
\hline Unemployed, student, home duties, other & $\begin{array}{l}0.0540^{*} \\
(0.0279)\end{array}$ & $\begin{array}{c}0.0226^{* *} \\
(0.0109)\end{array}$ & $\begin{array}{c}-0.0202^{*} \\
(0.0111)\end{array}$ & $\begin{array}{c}-0.0357^{* *} \\
(0.0178)\end{array}$ & $\begin{array}{c}-0.0207^{* *} \\
(0.0102)\end{array}$ \\
\hline Retired & $\begin{array}{c}0.0342 \\
(0.0424)\end{array}$ & $\begin{array}{c}0.0141 \\
(0.0159)\end{array}$ & $\begin{array}{l}-0.0129 \\
(0.0169)\end{array}$ & $\begin{array}{l}-0.0224 \\
(0.0266)\end{array}$ & $\begin{array}{l}-0.0129 \\
(0.0149)\end{array}$ \\
\hline \multicolumn{6}{|l|}{ Gender (reference cat.: Female) } \\
\hline Male & $\begin{array}{c}-0.00643 \\
(0.0284)\end{array}$ & $\begin{array}{c}-0.0547^{*} \\
(0.0298)\end{array}$ & $\begin{array}{c}0.0855^{* * *} \\
(0.0314)\end{array}$ & $\begin{array}{c}-0.0321 \\
(0.0256)\end{array}$ & $\begin{array}{l}0.00778 \\
(0.0162)\end{array}$ \\
\hline \multicolumn{6}{|c|}{ Broad region (reference cat.: Boarder, Midlands, West) } \\
\hline Dublin and Mid-East & $\begin{array}{l}-0.0242 \\
(0.0285)\end{array}$ & $\begin{array}{l}-0.0113 \\
(0.0137)\end{array}$ & $\begin{array}{c}0.00846 \\
(0.00977)\end{array}$ & $\begin{array}{c}0.0169 \\
(0.0203)\end{array}$ & $\begin{array}{c}0.0102 \\
(0.0123)\end{array}$ \\
\hline Mid-West, South-East and South-West & $\begin{array}{c}-0.0521^{* *} \\
(0.0265)\end{array}$ & $\begin{array}{l}-0.0252^{*} \\
(0.0138)\end{array}$ & $\begin{array}{l}0.0174^{* *} \\
(0.00858)\end{array}$ & $\begin{array}{l}0.0372^{*} \\
(0.0197)\end{array}$ & $\begin{array}{l}0.0227^{*} \\
(0.0125)\end{array}$ \\
\hline \multicolumn{6}{|l|}{ Tenure (reference cat.: Owner-occupied) } \\
\hline rented accomodation & $\begin{array}{c}-0.0357 \\
(0.0261)\end{array}$ & $\begin{array}{c}-0.0173 \\
(0.0136)\end{array}$ & $\begin{array}{c}0.0120 \\
(0.00835)\end{array}$ & $\begin{array}{c}0.0255 \\
(0.0194)\end{array}$ & $\begin{array}{c}0.0155 \\
(0.0122)\end{array}$ \\
\hline all other categories of tenure & $\begin{array}{c}-0.0824^{* *} \\
(0.0367)\end{array}$ & $\begin{array}{c}-0.0520^{*} \\
(0.0306)\end{array}$ & $\begin{array}{c}0.0168^{* * *} * \\
(0.00486)\end{array}$ & $\begin{array}{l}0.0689 * \\
(0.0369)\end{array}$ & $\begin{array}{c}0.0487 \\
(0.0315)\end{array}$ \\
\hline \multicolumn{6}{|c|}{ Length of residence (reference cat.: Less than 5 years) } \\
\hline $5-20$ years & $\begin{array}{c}0.0153 \\
(0.0323)\end{array}$ & $\begin{array}{c}0.00682 \\
(0.0141)\end{array}$ & $\begin{array}{c}-0.00555 \\
(0.0119)\end{array}$ & $\begin{array}{l}-0.0104 \\
(0.0218)\end{array}$ & $\begin{array}{c}-0.00615 \\
(0.0128)\end{array}$ \\
\hline More than 20 years & $\begin{array}{l}-0.0158 \\
(0.0335)\end{array}$ & $\begin{array}{r}-0.00720 \\
(0.0154)\end{array}$ & $\begin{array}{l}0.00560 \\
(0.0119)\end{array}$ & $\begin{array}{c}0.0109 \\
(0.0232)\end{array}$ & $\begin{array}{l}0.00647 \\
(0.0139)\end{array}$ \\
\hline \multicolumn{6}{|l|}{ Area of residence (reference cat.: Rural) } \\
\hline Urban & $\begin{array}{l}-0.0246 \\
(0.0308)\end{array}$ & $\begin{array}{l}-0.0116 \\
(0.0150)\end{array}$ & $\begin{array}{l}0.00853 \\
(0.0104)\end{array}$ & $\begin{array}{c}0.0173 \\
(0.0221)\end{array}$ & $\begin{array}{c}0.0104 \\
(0.0135)\end{array}$ \\
\hline \multicolumn{6}{|c|}{ Internal variables: satisfaction with local planning procedures } \\
\hline \multicolumn{6}{|c|}{ Satisfaction with local planning procedures (reference cat.: Satisfied) } \\
\hline Unsatisfied & $\begin{array}{c}0.199 * * * \\
(0.0380)\end{array}$ & $\begin{array}{c}0.0247 \\
(0.0352)\end{array}$ & $\begin{array}{c}-0.180 * * * \\
(0.0327)\end{array}$ & $\begin{array}{c}-0.0515^{*} \\
(0.0289)\end{array}$ & $\begin{array}{l}0.00727 \\
(0.0211)\end{array}$ \\
\hline \multicolumn{6}{|l|}{ Internal variables: national energy policy preferences } \\
\hline Tradeoff env. vs. econ. & $\begin{array}{c}-0.000990 \\
(0.0120)\end{array}$ & $\begin{array}{c}-0.00651 \\
(0.0121)\end{array}$ & $\begin{array}{c}-0.0493^{* * *} \\
(0.0113)\end{array}$ & $\begin{array}{c}0.0348^{* * *} \\
(0.0107)\end{array}$ & $\begin{array}{c}0.0219^{* * *} \\
(0.00670)\end{array}$ \\
\hline Tradeoff rel. vs. econ. & $\begin{array}{c}0.00438 \\
(0.0118)\end{array}$ & $\begin{array}{c}0.00199 \\
(0.00537)\end{array}$ & $\begin{array}{l}-0.00156 \\
(0.00424)\end{array}$ & $\begin{array}{l}-0.00301 \\
(0.00814)\end{array}$ & $\begin{array}{l}-0.00179 \\
(0.00483)\end{array}$ \\
\hline Tradeoff soc. vs. econ. & $0.0248^{* *}$ & $0.0112^{* *}$ & $-0.00886^{* *}$ & $-0.0171^{* *}$ & $-0.0101^{* *}$ \\
\hline Tradeoff rel. vs. env. & $\begin{array}{l}(0.0120) \\
-0.00231 \\
(0.0112)\end{array}$ & $\begin{array}{l}(0.00555) \\
-0.00105 \\
(0.00510)\end{array}$ & $\begin{array}{l}(0.00444) \\
0.000827 \\
(0.00402)\end{array}$ & $\begin{array}{c}(0.00830) \\
0.00159 \\
(0.00773)\end{array}$ & $\begin{array}{l}(0.000944 \\
0.000944)\end{array}$ \\
\hline Tradeoff soc. vs. env. & $\begin{array}{l}-0.0109 \\
(0.0132)\end{array}$ & $\begin{array}{l}-0.00493 \\
(0.00600)\end{array}$ & $\begin{array}{c}0.00388 \\
(0.00475)\end{array}$ & $\begin{array}{c}0.00748 \\
(0.00908)\end{array}$ & $\begin{array}{c}0.00443 \\
(0.00539)\end{array}$ \\
\hline Tradeoff soc. vs. rel. & $\begin{array}{c}-0.00132 \\
(0.0120)\end{array}$ & $\begin{array}{c}-0.000598 \\
(0.00543)\end{array}$ & $\begin{array}{l}0.000471 \\
(0.00427)\end{array}$ & $\begin{array}{l}0.000907 \\
(0.00823)\end{array}$ & $\begin{array}{c}0.000538 \\
(0.00488)\end{array}$ \\
\hline \multicolumn{6}{|c|}{ Internal variables: technology-specific criteria and preferences } \\
\hline Landscape & $\begin{array}{l}0.319^{*} \\
(0.180)\end{array}$ & $\begin{array}{c}0.145^{*} \\
(0.0833)\end{array}$ & $\begin{array}{l}-0.114^{*} \\
(0.0663)\end{array}$ & $\begin{array}{l}-0.220^{*} \\
(0.125)\end{array}$ & $\begin{array}{l}-0.130^{*} \\
(0.0747)\end{array}$ \\
\hline Local environment & $\begin{array}{c}-0.267 \\
(0.203)\end{array}$ & $\begin{array}{c}-0.121 \\
(0.0931)\end{array}$ & $\begin{array}{c}0.0955 \\
(0.0734)\end{array}$ & $\begin{array}{c}0.184 \\
(0.140)\end{array}$ & $\begin{array}{c}0.109 \\
(0.0835)\end{array}$ \\
\hline Local employment & $\begin{array}{l}0.0115 \\
(0.165)\end{array}$ & $\begin{array}{c}0.00522 \\
(0.0749)\end{array}$ & $\begin{array}{r}-0.00411 \\
(0.0590)\end{array}$ & $\begin{array}{c}-0.00792 \\
(0.114)\end{array}$ & $\begin{array}{c}-0.00470 \\
(0.0674)\end{array}$ \\
\hline Sound & $0.407 * *$ & $0.185^{* *}$ & $-0.145^{* *}$ & $-0.280^{* *}$ & $-0.166^{* *}$ \\
\hline & $(0.160)$ & $(0.0747)$ & $(0.0607)$ & $(0.111)$ & $(0.0667)$ \\
\hline Local economy & $\begin{array}{l}-0.329 \\
(0.210)\end{array}$ & -0.153 & -0.0358 & 0.0781 & $0.439^{* * *}$ \\
\hline Health & $\begin{array}{c}(0.210) \\
0.369^{*} \\
(0.216)\end{array}$ & $\begin{array}{c}(0.204) \\
-0.0219 \\
(0.192)\end{array}$ & $\begin{array}{c}(0.179) \\
-0.750^{* * *} \\
(0.191)\end{array}$ & $\begin{array}{c}(0.179) \\
0.260 \\
(0.178)\end{array}$ & $\begin{array}{c}(0.110) \\
0.144 \\
(0.113)\end{array}$ \\
\hline Observations & 956 & 956 & 956 & 956 & 956 \\
\hline
\end{tabular}

Note: Standard errors in parentheses. ${ }^{* * *} p<0.01,{ }^{* *} p<0.05,{ }^{*} p<0.1$. 
Table 6: WTA wind-farm development under a community benefit scheme

\begin{tabular}{|c|c|c|c|c|c|}
\hline External variables: socio-demographic characteristics & Unwilling & $\begin{array}{c}\text { Somewhat } \\
\text { unwilling }\end{array}$ & Neutral & $\begin{array}{c}\text { Somewhat } \\
\text { willing }\end{array}$ & Willing \\
\hline \multicolumn{6}{|l|}{ Age (reference cat.: Younger than 25) } \\
\hline $25-44$ & $\begin{array}{l}0.0311^{*} \\
(0.0173)\end{array}$ & $\begin{array}{l}0.0311^{*} \\
(0.0166)\end{array}$ & $\begin{array}{c}0.0272 * * \\
(0.0137)\end{array}$ & $\begin{array}{l}-0.0249^{*} \\
(0.0149)\end{array}$ & $\begin{array}{c}-0.0645^{* *} \\
(0.0326)\end{array}$ \\
\hline $45-59$ & $0.0701 * * *$ & $0.0642 * * *$ & $0.0479 * * *$ & $-0.0623^{* * *} *$ & $-0.120^{* * *}$ \\
\hline 60 or older & $\begin{array}{c}(0.0235) \\
0.0712 * * \\
(0.0293)\end{array}$ & $\begin{array}{c}(0.0190) \\
0.0655^{* * *} * \\
(0.0238)\end{array}$ & $\begin{array}{c}(0.0113) \\
0.0495^{* * *} \\
(0.0141)\end{array}$ & $\begin{array}{c}(0.0226) \\
-0.0625^{* *} \\
(0.0276)\end{array}$ & $\begin{array}{c}(0.0301) \\
-0.124^{* * *} \\
(0.0388)\end{array}$ \\
\hline \multicolumn{6}{|c|}{ Highest level of education (reference cat.: Primary school) } \\
\hline Leaving certificate & $\begin{array}{c}-0.000983 \\
(0.0175)\end{array}$ & $\begin{array}{r}-0.00102 \\
(0.0182)\end{array}$ & $\begin{array}{c}-0.000952 \\
(0.0170)\end{array}$ & $\begin{array}{c}0.000720 \\
(0.0128)\end{array}$ & $\begin{array}{l}0.00223 \\
(0.0399)\end{array}$ \\
\hline Post-secondary non-tertiary & $\begin{array}{l}0.00177 \\
(0.0184)\end{array}$ & $\begin{array}{l}0.00183 \\
(0.0190)\end{array}$ & $\begin{array}{l}0.00169 \\
(0.0175)\end{array}$ & $\begin{array}{l}-0.00132 \\
(0.0139)\end{array}$ & $\begin{array}{l}-0.00397 \\
(0.0410)\end{array}$ \\
\hline Third level non-honours degree & $\begin{array}{r}-0.00769 \\
(0.0177)\end{array}$ & $\begin{array}{c}-0.00805 \\
(0.0188)\end{array}$ & $\begin{array}{r}-0.00771 \\
(0.0184)\end{array}$ & $\begin{array}{l}0.00535 \\
(0.0116)\end{array}$ & $\begin{array}{c}0.0181 \\
(0.0433)\end{array}$ \\
\hline Third level honours or above & $\begin{array}{l}-0.0280^{*} \\
(0.0161)\end{array}$ & $\begin{array}{l}-0.0302^{*} \\
(0.0180)\end{array}$ & $\begin{array}{l}-0.0309 \\
(0.0200)\end{array}$ & $\begin{array}{l}0.0156^{* *} \\
(0.00653)\end{array}$ & $\begin{array}{c}0.0735 \\
(0.0484)\end{array}$ \\
\hline \multicolumn{6}{|l|}{ Income (reference cat.: Less than 15,000 ) } \\
\hline 15,000 to 30,000 & $\begin{array}{l}-0.0157 \\
(0.0145)\end{array}$ & $\begin{array}{l}-0.0164 \\
(0.0154)\end{array}$ & $\begin{array}{l}-0.0158 \\
(0.0152)\end{array}$ & $\begin{array}{c}0.0108 \\
(0.00940)\end{array}$ & $\begin{array}{c}0.0371 \\
(0.0359)\end{array}$ \\
\hline 30,000 to 50,000 & $\begin{array}{c}-0.00564 \\
(0.0160)\end{array}$ & $\begin{array}{c}-0.00588 \\
(0.0167)\end{array}$ & $\begin{array}{l}-0.00557 \\
(0.0161)\end{array}$ & $\begin{array}{l}0.00403 \\
(0.0110)\end{array}$ & $\begin{array}{c}0.0131 \\
(0.0378)\end{array}$ \\
\hline 50,000 to 75,000 & $\begin{array}{c}-0.0263^{*} \\
(0.0152)\end{array}$ & $\begin{array}{r}-0.0285^{*} \\
(0.0173)\end{array}$ & $\begin{array}{l}-0.0295 \\
(0.0196)\end{array}$ & $\begin{array}{l}0.0140 * * \\
(0.00554)\end{array}$ & $\begin{array}{c}0.0703 \\
(0.0476)\end{array}$ \\
\hline 75,000 or more & $\begin{array}{c}0.000126 \\
(0.0214)\end{array}$ & $\begin{array}{c}0.000130 \\
(0.0221)\end{array}$ & $\begin{array}{c}0.000121 \\
(0.0206)\end{array}$ & $\begin{array}{c}-9.27 \mathrm{e}-05 \\
(0.0158)\end{array}$ & $\begin{array}{c}-0.000285 \\
(0.0484)\end{array}$ \\
\hline \multicolumn{6}{|l|}{ Employment (reference cat.: In employment) } \\
\hline Unemployed, student, home duties, other & $\begin{array}{l}0.00528 \\
(0.0121)\end{array}$ & $\begin{array}{l}0.00543 \\
(0.0124)\end{array}$ & $\begin{array}{l}0.00502 \\
(0.0114)\end{array}$ & $\begin{array}{l}-0.00395 \\
(0.00926)\end{array}$ & $\begin{array}{l}-0.0118 \\
(0.0267)\end{array}$ \\
\hline Retired & $\begin{array}{l}0.0364^{*} \\
(0.0217)\end{array}$ & $\begin{array}{l}0.0353^{*} \\
(0.0198)\end{array}$ & $\begin{array}{l}0.0292^{* *} \\
(0.0144)\end{array}$ & $\begin{array}{l}-0.0311 \\
(0.0205)\end{array}$ & $\begin{array}{c}-0.0698^{* *} \\
(0.0352)\end{array}$ \\
\hline \multicolumn{6}{|l|}{ Gender (reference cat.: Female) } \\
\hline Male & $\begin{array}{c}-0.0118 \\
(0.00993)\end{array}$ & $\begin{array}{l}-0.0122 \\
(0.0103)\end{array}$ & $\begin{array}{c}-0.0114 \\
(0.00963)\end{array}$ & $\begin{array}{c}0.00870 \\
(0.00744)\end{array}$ & $\begin{array}{c}0.0268 \\
(0.0224)\end{array}$ \\
\hline \multicolumn{6}{|c|}{ Broad region (reference cat.: Boarder, Midlands, West) } \\
\hline Dublin and Mid-East & $\begin{array}{c}-0.00654 \\
(0.0130)\end{array}$ & $\begin{array}{r}-0.00680 \\
(0.0136)\end{array}$ & $\begin{array}{c}-0.00640 \\
(0.0129)\end{array}$ & $\begin{array}{c}0.00473 \\
(0.00927)\end{array}$ & $\begin{array}{c}0.0150 \\
(0.0303)\end{array}$ \\
\hline Mid-West, South-East and South-West & $\begin{array}{c}-0.00129 \\
(0.0129)\end{array}$ & $\begin{array}{c}-0.00133 \\
(0.0134)\end{array}$ & $\begin{array}{c}-0.00125 \\
(0.0125)\end{array}$ & $\begin{array}{l}0.000944 \\
(0.00940)\end{array}$ & $\begin{array}{l}0.00292 \\
(0.0294)\end{array}$ \\
\hline Tenure (reference cat.: Owner-occupied) & & & & & \\
\hline rented accomodation & $\begin{array}{l}-0.00820 \\
(0.0121)\end{array}$ & $\begin{array}{r}-0.00856 \\
(0.0127)\end{array}$ & $\begin{array}{r}-0.00815 \\
(0.0123)\end{array}$ & $\begin{array}{c}0.00578 \\
(0.00817)\end{array}$ & $\begin{array}{c}0.0191 \\
(0.0290)\end{array}$ \\
\hline all other categories of tenure & $\begin{array}{l}-0.0102 \\
(0.0205)\end{array}$ & $\begin{array}{l}-0.0108 \\
(0.0224)\end{array}$ & $\begin{array}{l}-0.0107 \\
(0.0232)\end{array}$ & $\begin{array}{l}0.00659 \\
(0.0112)\end{array}$ & $\begin{array}{c}0.0251 \\
(0.0549)\end{array}$ \\
\hline Length of residence (reference cat.: Less than 5 & ears) & & & & \\
\hline $5-20$ years & $\begin{array}{l}0.00642 \\
(0.0148)\end{array}$ & $\begin{array}{c}0.00660 \\
(0.0152)\end{array}$ & $\begin{array}{l}0.00610 \\
(0.0139)\end{array}$ & $\begin{array}{c}-0.00481 \\
(0.0113)\end{array}$ & $\begin{array}{l}-0.0143 \\
(0.0326)\end{array}$ \\
\hline More than 20 years & $\begin{array}{r}-0.00585 \\
(0.0153)\end{array}$ & $\begin{array}{r}-0.00606 \\
(0.0159)\end{array}$ & $\begin{array}{r}-0.00567 \\
(0.0149)\end{array}$ & $\begin{array}{l}0.00428 \\
(0.0112)\end{array}$ & $\begin{array}{c}0.0133 \\
(0.0350)\end{array}$ \\
\hline Area of residence (reference cat.: Rural) & & & & & \\
\hline Urban & $\begin{array}{c}-0.00845 \\
(0.0141)\end{array}$ & $\begin{array}{c}-0.00880 \\
(0.0148)\end{array}$ & $\begin{array}{c}-0.00834 \\
(0.0143)\end{array}$ & $\begin{array}{c}0.00601 \\
(0.00973)\end{array}$ & $\begin{array}{c}0.0196 \\
(0.0335)\end{array}$ \\
\hline Internal variables: satisfaction with local planning pro & edures & & & & \\
\hline Satisfaction with local planning procedures (refe & ence cat.: $\mathrm{S}$ & isfied) & & & \\
\hline Unsatisfied & $\begin{array}{c}0.0464 * * * \\
(0.0153)\end{array}$ & $\begin{array}{c}0.0442^{* * *} \\
(0.0136)\end{array}$ & $\begin{array}{c}0.0352 * * * \\
(0.00925)\end{array}$ & $\begin{array}{c}-0.0405^{* * *} \\
(0.0152)\end{array}$ & $\begin{array}{c}-0.0852^{* * * *} \\
(0.0224)\end{array}$ \\
\hline Internal variables: national energy policy preferences & & & & & \\
\hline Tradeoff env. vs. econ. & $\begin{array}{c}-0.00409 \\
(0.00694)\end{array}$ & $\begin{array}{l}-0.00284 \\
(0.00817)\end{array}$ & $\begin{array}{c}-0.0471^{* * *} \\
(0.0103)\end{array}$ & $\begin{array}{c}-0.00143 \\
(0.0138)\end{array}$ & $\begin{array}{c}0.0555^{* * *} \\
(0.0127)\end{array}$ \\
\hline Tradeoff rel. vs. econ. & $\begin{array}{c}-0.00679 \\
(0.00548)\end{array}$ & $\begin{array}{l}-0.00703 \\
(0.00566)\end{array}$ & $\begin{array}{l}-0.00656 \\
(0.00531)\end{array}$ & $\begin{array}{c}0.00500 \\
(0.00410)\end{array}$ & $\begin{array}{c}0.0154 \\
(0.0124)\end{array}$ \\
\hline Tradeoff soc. vs. econ. & 0.00659 & $\begin{array}{c}0.00682 \\
(0.00558)\end{array}$ & 0.00636 & -0.00485 & $\begin{array}{l}-0.0149 \\
(0.0122)\end{array}$ \\
\hline Tradeoff rel. vs. env. & $\begin{array}{l}(0.00539) \\
-0.00645\end{array}$ & $\begin{array}{l}(0.00558) \\
-0.00667\end{array}$ & $\begin{array}{l}(0.00521) \\
-0.00623\end{array}$ & $\begin{array}{c}(0.00404) \\
0.00475\end{array}$ & 0.0146 \\
\hline & $(0.00499)$ & $(0.00517)$ & $(0.00484)$ & $(0.00375)$ & $(0.0113)$ \\
\hline Tradeoff soc. vs. env. & $0.0108^{*}$ & $0.0112^{*}$ & $0.0105^{*}$ & $-0.00797^{*}$ & $-0.0245^{*}$ \\
\hline Tradeoff soc. vs. rel. & $\begin{array}{l}(0.00589) \\
-0.00519\end{array}$ & $\begin{array}{l}(0.00610) \\
-0.00537\end{array}$ & $\begin{array}{l}(0.00573) \\
-0.00501\end{array}$ & $\begin{array}{c}(0.00453) \\
0.00382\end{array}$ & 0.0117 \\
\hline & $(0.00540)$ & $(0.00559)$ & $(0.00522)$ & $(0.00403)$ & $(0.0122)$ \\
\hline Internal variables: technology-specific criteria and $p$ & erences & & & & \\
\hline Landscape & $0.141^{*}$ & $0.146^{*}$ & $0.136^{*}$ & -0.104 & $-0.318^{*}$ \\
\hline Local environment & $\begin{array}{c}(0.0835 \\
0.130\end{array}$ & $\begin{array}{l}(0.0864) \\
-0.0975\end{array}$ & $\begin{array}{c}(0.0808) \\
-0.703^{*} * *\end{array}$ & 0.211 & $0.188)$ \\
\hline & $(0.128)$ & $(0.147)$ & $(0.168)$ & $(0.195)$ & $(0.230)$ \\
\hline Local employment & -0.0269 & -0.0278 & -0.0260 & 0.0198 & 0.0609 \\
\hline & $(0.0776)$ & $(0.0803)$ & $(0.0750)$ & $(0.0572)$ & $(0.176)$ \\
\hline Sound & $0.197 * * *$ & $0.204^{* * *}$ & $0.190^{* * *}$ & $-0.145^{* *}$ & $-0.446 * * *$ \\
\hline & $(0.0738)$ & $(0.0771)$ & $(0.0722)$ & $(0.0592)$ & $(0.165)$ \\
\hline Local economy & $-0.174^{* *}$ & $-0.180^{* *}$ & $-0.168^{* *}$ & $0.128^{* *}$ & $0.395^{* *}$ \\
\hline & $(0.0818)$ & $(0.0850)$ & $(0.0798)$ & $(0.0637)$ & $(0.183)$ \\
\hline Health & $\begin{array}{c}-0.127 \\
(0.0812)\end{array}$ & $\begin{array}{c}-0.132 \\
(0.0840)\end{array}$ & $\begin{array}{c}-0.123 \\
(0.0785)\end{array}$ & $\begin{array}{c}0.0937 \\
(0.0620)\end{array}$ & $\begin{array}{c}0.288 \\
(0.182)\end{array}$ \\
\hline Observations & 977 & 977 & 977 & 977 & 977 \\
\hline
\end{tabular}

Note: Standard errors in parentheses. ${ }^{* * *} p<0.01,{ }^{* *} p<0.05,{ }^{*} p<0.1$. 
Table 7: WTA wind-farm development under equity involvement

\begin{tabular}{|c|c|c|c|c|c|}
\hline External variables: socio-demographic characteristics & Unwilling & $\begin{array}{c}\text { Somewhat } \\
\text { unwilling }\end{array}$ & Neutral & $\begin{array}{c}\text { Somewhat } \\
\text { willing }\end{array}$ & Willing \\
\hline \multicolumn{6}{|l|}{ Age (reference cat.: Younger than 25) } \\
\hline $25-44$ & $\begin{array}{c}0.0440 * * \\
(0.0198)\end{array}$ & $\begin{array}{c}0.0411^{* *} \\
(0.0175)\end{array}$ & $\begin{array}{c}0.0353^{* * * *} \\
(0.0134)\end{array}$ & $\begin{array}{c}-0.0493^{* *} \\
(0.0219)\end{array}$ & $\begin{array}{c}-0.0711^{* *} \\
(0.0282)\end{array}$ \\
\hline $45-59$ & $0.0890^{* * *}$ & -0.0124 & $\begin{array}{l}0.0820^{* *} \\
(0.0341)\end{array}$ & -0.0560 & $-0.103^{* * *}$ \\
\hline 60 or older & $\begin{array}{l}0.0575 * \\
(0.0294)\end{array}$ & $\begin{array}{l}0.0516^{* *} \\
(0.0239)\end{array}$ & $\begin{array}{c}0.0399^{* * * *} \\
(0.0142)\end{array}$ & $\begin{array}{c}-0.0641^{* *} \\
(0.0315)\end{array}$ & $\begin{array}{c}-0.0849^{* *} \\
(0.0350)\end{array}$ \\
\hline \multicolumn{6}{|c|}{ Highest level of education (reference cat.: Primary school) } \\
\hline Leaving certificate & $\begin{array}{r}-0.00102 \\
(0.0192)\end{array}$ & $\begin{array}{c}-0.00101 \\
(0)\end{array}$ & $\begin{array}{c}-0.000984 \\
(0.0186)\end{array}$ & $\begin{array}{l}0.00115 \\
(0.0215)\end{array}$ & $\begin{array}{l}0.00187 \\
(0.0353)\end{array}$ \\
\hline Post-secondary non-tertiary & $\begin{array}{c}0.0135 \\
(0.0215)\end{array}$ & $\begin{array}{c}0.0130 \\
(0.0202)\end{array}$ & $\begin{array}{c}0.0119 \\
(0.0173)\end{array}$ & $\begin{array}{l}-0.0153 \\
(0.0245)\end{array}$ & $\begin{array}{l}-0.0230 \\
(0.0345)\end{array}$ \\
\hline Third level non-honours degree & $\begin{array}{c}0.0361 \\
(0.0334)\end{array}$ & $\begin{array}{l}0.00645 \\
(0.0329)\end{array}$ & $\begin{array}{c}-0.104 * * * \\
(0.0372)\end{array}$ & $\begin{array}{c}0.0383 \\
(0.0421)\end{array}$ & $\begin{array}{c}0.0235 \\
(0.0446)\end{array}$ \\
\hline Third level honours or above & $\begin{array}{l}-0.00758 \\
(0.0200)\end{array}$ & $\begin{array}{l}-0.00754 \\
(0.0201)\end{array}$ & $\begin{array}{l}-0.00761 \\
(0.0210)\end{array}$ & $\begin{array}{l}0.00842 \\
(0.0220)\end{array}$ & $\begin{array}{c}0.0143 \\
(0.0392)\end{array}$ \\
\hline \multicolumn{6}{|l|}{ Income (reference cat.: Less than 15,000 ) } \\
\hline 15,000 to 30,000 & $\begin{array}{l}0.00361 \\
(0.0167)\end{array}$ & $\begin{array}{l}0.00353 \\
(0.0163)\end{array}$ & $\begin{array}{l}0.00341 \\
(0.0156)\end{array}$ & $\begin{array}{l}-0.00406 \\
(0.0188)\end{array}$ & $\begin{array}{r}-0.00650 \\
(0.0298)\end{array}$ \\
\hline 30,000 to 50,000 & $\begin{array}{c}-0.00346 \\
(0.0175)\end{array}$ & $\begin{array}{c}-0.00342 \\
(0.0173)\end{array}$ & $\begin{array}{c}-0.00337 \\
(0.0173)\end{array}$ & $\begin{array}{l}0.00387 \\
(0.0195)\end{array}$ & $\begin{array}{l}0.00638 \\
(0.0327)\end{array}$ \\
\hline 50,000 to 75,000 & $\begin{array}{l}-0.0308^{*} \\
(0.0164)\end{array}$ & $\begin{array}{l}-0.0320^{*} \\
(0.0178)\end{array}$ & $\begin{array}{l}-0.0369 \\
(0.0237)\end{array}$ & $\begin{array}{l}0.0318^{* *} \\
(0.0148)\end{array}$ & $\begin{array}{c}0.0679 \\
(0.0431)\end{array}$ \\
\hline 75,000 or more & $\begin{array}{l}-0.0129 \\
(0.0210)\end{array}$ & $\begin{array}{c}-0.0130 \\
(0.0219)\end{array}$ & $\begin{array}{l}-0.0138 \\
(0.0251)\end{array}$ & $\begin{array}{c}0.0141 \\
(0.0221)\end{array}$ & $\begin{array}{c}0.0257 \\
(0.0458)\end{array}$ \\
\hline \multicolumn{6}{|l|}{ Employment (reference cat.: In employment) } \\
\hline Unemployed, student, home duties, other & $\begin{array}{l}0.00571 \\
(0.0134)\end{array}$ & $\begin{array}{l}0.00558 \\
(0.0130)\end{array}$ & $\begin{array}{l}0.00536 \\
(0.0123)\end{array}$ & $\begin{array}{c}-0.00642 \\
(0.0151)\end{array}$ & $\begin{array}{l}-0.0102 \\
(0.0236)\end{array}$ \\
\hline Retired & $\begin{array}{c}0.0202 \\
(0.0216)\end{array}$ & $\begin{array}{c}0.0192 \\
(0.0198)\end{array}$ & $\begin{array}{c}0.0170 \\
(0.0159)\end{array}$ & $\begin{array}{l}-0.0229 \\
(0.0246)\end{array}$ & $\begin{array}{l}-0.0335 \\
(0.0326)\end{array}$ \\
\hline \multicolumn{6}{|l|}{ Gender (reference cat.: Female) } \\
\hline Male & $\begin{array}{r}-0.00812 \\
(0.0183)\end{array}$ & $\begin{array}{c}-0.0610^{* * *} \\
(0.0213)\end{array}$ & $\begin{array}{c}0.0797 * * * \\
(0.0285)\end{array}$ & $\begin{array}{c}-0.0531^{*} \\
(0.0315)\end{array}$ & $\begin{array}{c}0.0425 \\
(0.0266)\end{array}$ \\
\hline \multicolumn{6}{|c|}{ Broad region (reference cat.: Boarder, Midlands, West) } \\
\hline Dublin and Mid-East & $\begin{array}{c}0.0121 \\
(0.0149)\end{array}$ & $\begin{array}{c}0.0118 \\
(0.0143)\end{array}$ & $\begin{array}{c}0.0112 \\
(0.0133)\end{array}$ & $\begin{array}{l}-0.0136 \\
(0.0168)\end{array}$ & $\begin{array}{l}-0.0215 \\
(0.0257)\end{array}$ \\
\hline Mid-West, South-East and South-West & $\begin{array}{l}0.0334^{* *} \\
(0.0156)\end{array}$ & $\begin{array}{l}0.0317^{* *} \\
(0.0143)\end{array}$ & $\begin{array}{c}0.0285^{* *} \\
(0.0119)\end{array}$ & $\begin{array}{c}-0.0376^{* *} \\
(0.0175)\end{array}$ & $\begin{array}{c}-0.0561 * * \\
(0.0239)\end{array}$ \\
\hline Tenure (reference cat.: Owner-occupied) & & & & & \\
\hline rented accomodation & $\begin{array}{l}-0.0153 \\
(0.0128)\end{array}$ & $\begin{array}{l}-0.0153 \\
(0.0130)\end{array}$ & $\begin{array}{l}-0.0157 \\
(0.0140)\end{array}$ & $\begin{array}{c}0.0169 \\
(0.0138)\end{array}$ & $\begin{array}{c}0.0295 \\
(0.0259)\end{array}$ \\
\hline all other categories of tenure & $-0.0396 * *$ & $-0.0431^{* *}$ & $-0.0562^{*}$ & $0.0355 * * *$ & $\begin{array}{l}0.103^{*} \\
(0.0596)\end{array}$ \\
\hline Length of residence (reference cat.: Less than 5 & ars) & $(0.0194)$ & $(0.0318)$ & $(0.00904)$ & $(0.0596)$ \\
\hline $5-20$ years & $\begin{array}{l}0.0291^{*} \\
(0.0172)\end{array}$ & $\begin{array}{l}0.0278^{*} \\
(0.0160)\end{array}$ & $\begin{array}{l}0.0253^{*} \\
(0.0137)\end{array}$ & $\begin{array}{c}-0.0327^{*} \\
(0.0193)\end{array}$ & $\begin{array}{c}-0.0495^{*} \\
(0.0272)\end{array}$ \\
\hline More than 20 years & $\begin{array}{c}0.0253 \\
(0.0227)\end{array}$ & $\begin{array}{c}0.0334 \\
(0.0246)\end{array}$ & $\begin{array}{c}-0.0774^{* * *} \\
(0.0299)\end{array}$ & $\begin{array}{c}0.0388 \\
(0.0356)\end{array}$ & $\begin{array}{l}-0.0201 \\
(0.0345)\end{array}$ \\
\hline Area of residence (reference cat.: Rural) & & & & & \\
\hline Urban & $\begin{array}{l}-0.0316 \\
(0.0206)\end{array}$ & $\begin{array}{c}-0.0487^{* *} \\
(0.0225)\end{array}$ & $\begin{array}{l}0.00795 \\
(0.0327)\end{array}$ & $\begin{array}{c}0.116 * * * \\
(0.0360)\end{array}$ & $\begin{array}{l}-0.0435 \\
(0.0323)\end{array}$ \\
\hline Internal variables: satisfaction with local planning pre & dures & & & & \\
\hline Satisfaction with local planning procedures (ref & nce cat.: Sa & sfied) & & & \\
\hline Unsatisfied & $\begin{array}{c}0.0897 * * * \\
(0.0274)\end{array}$ & $\begin{array}{l}0.00755 \\
(0.0264)\end{array}$ & $\begin{array}{l}-0.0387 \\
(0.0338)\end{array}$ & $\begin{array}{l}-0.0446 \\
(0.0373)\end{array}$ & $\begin{array}{l}-0.0139 \\
(0.0312)\end{array}$ \\
\hline Internal variables: national energy policy preferences & & & & & \\
\hline Tradeoff env. vs. econ. & $\begin{array}{l}-0.0208^{* * *} \\
(0.00518)\end{array}$ & $\begin{array}{c}-0.0204^{* * *} \\
(0.00517)\end{array}$ & $\begin{array}{c}-0.0199^{* * *} \\
(0.00526)\end{array}$ & $\begin{array}{l}0.0233^{* * *} \\
(0.00605)\end{array}$ & $\begin{array}{r}0.0378^{* * *} \\
(0.00917)\end{array}$ \\
\hline Tradeoff rel. vs. econ. & $\begin{array}{c}0.0113 \\
(0.00849)\end{array}$ & $\begin{array}{c}0.00840 \\
(0.00960)\end{array}$ & $\begin{array}{c}-0.0488^{* * *} \\
(0.0128)\end{array}$ & $\begin{array}{c}-0.00571 \\
(0.0148)\end{array}$ & $\begin{array}{c}0.0349 * * * \\
(0.0135)\end{array}$ \\
\hline Tradeoff soc. vs. econ. & $0.0120^{* *}$ & $0.0118^{* *}$ & $0.0115^{* *}$ & $-0.0135 * *$ & $-0.0219^{* *}$ \\
\hline & $(0.00602)$ & $(0.00592)$ & $(0.00582)$ & $(0.00681)$ & $(0.0108)$ \\
\hline Tradeoff rel. vs. env. & $\begin{array}{l}-0.00542 \\
(0.00547)\end{array}$ & $\begin{array}{l}-0.00532 \\
(0.00536)\end{array}$ & $\begin{array}{l}-0.00518 \\
(0.00523)\end{array}$ & $\begin{array}{c}0.00608 \\
(0.00614)\end{array}$ & $\begin{array}{c}0.00985 \\
(0.00990)\end{array}$ \\
\hline Tradeoff soc. vs. env. & 0.00772 & 0.00758 & 0.00738 & $\begin{array}{l}-0.00865 \\
(0.00722)\end{array}$ & -0.0140 \\
\hline & $(0.00642)$ & $(0.00630)$ & $(0.00617)$ & $(0.00722)$ & $(0.0116)$ \\
\hline Tradeoff soc. vs. rel. & $-0.0152^{*}$ & -0.00363 & 0.0116 & 0.0175 & -0.0103 \\
\hline & $(0.00838)$ & $(0.00914)$ & $(0.0115)$ & $(0.0125)$ & $(0.0122)$ \\
\hline Internal variables: technology-specific criteria and pre & rences & & & & \\
\hline Landscape & $\begin{array}{c}0.104 \\
(0.0891)\end{array}$ & $\begin{array}{c}0.102 \\
(0.0876)\end{array}$ & $\begin{array}{c}0.0996 \\
(0.0854)\end{array}$ & $\begin{array}{c}-0.117 \\
(0.100)\end{array}$ & $\begin{array}{c}-0.189 \\
(0.161)\end{array}$ \\
\hline Local environment & $\begin{array}{l}0.0211 \\
(0.135)\end{array}$ & $\begin{array}{l}0.260^{*} \\
(0.150)\end{array}$ & $\begin{array}{c}-0.853^{* * *} \\
(0.199)\end{array}$ & $\begin{array}{c}0.110 \\
(0.204)\end{array}$ & $\begin{array}{c}0.463^{* *} \\
(0.204)\end{array}$ \\
\hline Local employment & -0.0629 & -0.0617 & -0.0602 & 0.0705 & 0.114 \\
\hline & $(0.0838)$ & $(0.0822)$ & $(0.0802)$ & $(0.0940)$ & $(0.152)$ \\
\hline Sound & $0.323^{* * *}$ & -0.0234 & 0.298 & $-0.599 * * *$ & 0.000287 \\
\hline & $(0.125)$ & $(0.145)$ & $(0.185)$ & $(0.207)$ & $(0.177)$ \\
\hline Local economy & -0.0725 & -0.0712 & -0.0694 & 0.0813 & 0.132 \\
\hline Health & $(0.0878)$ & $(0.0863)$ & $(0.0842)$ & $(0.0987)$ & $(0.159)$ \\
\hline Health & $\begin{array}{l}-0.0988 \\
(0.0879)\end{array}$ & $\begin{array}{l}-0.0970 \\
(0.0863)\end{array}$ & $\begin{array}{l}-0.0945 \\
(0.0842)\end{array}$ & $\begin{array}{c}0.111 \\
(0.0989)\end{array}$ & $\begin{array}{c}0.180 \\
(0.159)\end{array}$ \\
\hline Observations & 959 & 959 & 959 & 959 & 959 \\
\hline
\end{tabular}


Table 8: WTA wind-farm development under a joint venture

\begin{tabular}{|c|c|c|c|c|c|}
\hline External variables: socio-demographic characteristics & Unwilling & $\begin{array}{c}\text { Somewhat } \\
\text { unwilling }\end{array}$ & Neutral & $\begin{array}{c}\text { Somewhat } \\
\text { willing }\end{array}$ & Willing \\
\hline \multicolumn{6}{|l|}{ Age (reference cat.: Younger than 25) } \\
\hline $25-44$ & $\begin{array}{l}-0.0293 \\
(0.0231)\end{array}$ & $\begin{array}{r}0.00949 \\
(0.0282)\end{array}$ & $\begin{array}{c}0.0776^{* *} \\
(0.0334)\end{array}$ & $\begin{array}{r}-0.00819 \\
(0.0370)\end{array}$ & $\begin{array}{l}-0.0496^{*} \\
(0.0300)\end{array}$ \\
\hline \multirow[t]{2}{*}{$45-59$} & 0.0215 & 0.0218 & 0.0139 & -0.0264 & -0.0309 \\
\hline & $(0.0206)$ & $(0.0201)$ & $(0.0112)$ & $(0.0247)$ & $(0.0270)$ \\
\hline 60 or older & $\begin{array}{c}0.0259 \\
(0.0263)\end{array}$ & $\begin{array}{c}0.0262 \\
(0.0254)\end{array}$ & $\begin{array}{c}0.0165 \\
(0.0136)\end{array}$ & $\begin{array}{l}-0.0317 \\
(0.0312)\end{array}$ & $\begin{array}{l}-0.0369 \\
(0.0338)\end{array}$ \\
\hline \multicolumn{6}{|c|}{ Highest level of education (reference cat.: Primary school) } \\
\hline Leaving certificate & $\begin{array}{c}-0.00748 \\
(0.0194)\end{array}$ & $\begin{array}{c}-0.00794 \\
(0.0208)\end{array}$ & $\begin{array}{c}-0.00605 \\
(0.0165)\end{array}$ & $\begin{array}{l}0.00938 \\
(0.0244)\end{array}$ & $\begin{array}{c}0.0121 \\
(0.0323)\end{array}$ \\
\hline Post-secondary non-tertiary & $\begin{array}{l}0.00268 \\
(0.0209)\end{array}$ & $\begin{array}{c}0.00281 \\
(0.0218)\end{array}$ & $\begin{array}{l}0.00202 \\
(0.0154)\end{array}$ & $\begin{array}{c}-0.00335 \\
(0.0261)\end{array}$ & $\begin{array}{l}-0.00416 \\
(0.0320)\end{array}$ \\
\hline Third level non-honours degree & $\begin{array}{c}0.000653 \\
(0.0213)\end{array}$ & $\begin{array}{l}0.000686 \\
(0.0224)\end{array}$ & $\begin{array}{c}0.000499 \\
(0.0162)\end{array}$ & $\begin{array}{c}-0.000816 \\
(0.0267)\end{array}$ & $\begin{array}{l}-0.00102 \\
(0.0333)\end{array}$ \\
\hline Third level honours or above & $\begin{array}{l}-0.0237 \\
(0.0190)\end{array}$ & $\begin{array}{l}-0.0260 \\
(0.0215)\end{array}$ & $\begin{array}{c}-0.0222 \\
(0.0212)\end{array}$ & $\begin{array}{c}0.0298 \\
(0.0237)\end{array}$ & $\begin{array}{c}0.0421 \\
(0.0378)\end{array}$ \\
\hline \multicolumn{6}{|l|}{ Income (reference cat.: Less than 15,000 ) } \\
\hline 15,000 to 30,000 & $\begin{array}{l}0.0485^{*} \\
(0.0285)\end{array}$ & $\begin{array}{c}0.0424 \\
(0.0311)\end{array}$ & $\begin{array}{c}-0.0979^{* * *} \\
(0.0355)\end{array}$ & $\begin{array}{r}-0.00545 \\
(0.0380)\end{array}$ & $\begin{array}{c}0.0125 \\
(0.0348)\end{array}$ \\
\hline 30,000 to 50,000 & $\begin{array}{l}0.00839 \\
(0.0193)\end{array}$ & $\begin{array}{l}0.00871 \\
(0.0198)\end{array}$ & $\begin{array}{c}0.00608 \\
(0.0132)\end{array}$ & $\begin{array}{l}-0.0104 \\
(0.0238)\end{array}$ & $\begin{array}{l}-0.0127 \\
(0.0284)\end{array}$ \\
\hline 50,000 to 75,000 & $\begin{array}{c}0.0102 \\
(0.0345)\end{array}$ & $\begin{array}{c}0.0610 \\
(0.0433)\end{array}$ & $\begin{array}{c}-0.166^{* * *} \\
(0.0436)\end{array}$ & $\begin{array}{c}0.0464 \\
(0.0491)\end{array}$ & $\begin{array}{c}0.0488 \\
(0.0469)\end{array}$ \\
\hline 75,000 or more & $\begin{array}{c}-0.00104 \\
(0.0378)\end{array}$ & $\begin{array}{c}0.0727 \\
(0.0516)\end{array}$ & $\begin{array}{c}-0.133^{* *} \\
(0.0526)\end{array}$ & $\begin{array}{r}-0.00551 \\
(0.0584)\end{array}$ & $\begin{array}{c}0.0669 \\
(0.0580)\end{array}$ \\
\hline \multicolumn{6}{|l|}{ Employment (reference cat.: In employment) } \\
\hline Unemployed, student, home duties, other & $\begin{array}{c}-0.00268 \\
(0.0135)\end{array}$ & $\begin{array}{c}-0.00282 \\
(0.0143)\end{array}$ & $\begin{array}{c}-0.00208 \\
(0.0106)\end{array}$ & $\begin{array}{l}0.00335 \\
(0.0169)\end{array}$ & $\begin{array}{l}0.00423 \\
(0.0215)\end{array}$ \\
\hline Retired & $\begin{array}{c}0.0220 \\
(0.0223)\end{array}$ & $\begin{array}{c}0.0223 \\
(0.0217)\end{array}$ & $\begin{array}{c}0.0140 \\
(0.0116)\end{array}$ & $\begin{array}{l}-0.0270 \\
(0.0267)\end{array}$ & $\begin{array}{l}-0.0313 \\
(0.0287)\end{array}$ \\
\hline \multicolumn{6}{|l|}{ Gender (reference cat.: Female) } \\
\hline Male & $\begin{array}{c}-0.0147 \\
(0.0113)\end{array}$ & $\begin{array}{l}-0.0155 \\
(0.0119)\end{array}$ & $\begin{array}{c}-0.0113 \\
(0.00877)\end{array}$ & $\begin{array}{c}0.0184 \\
(0.0141)\end{array}$ & $\begin{array}{c}0.0231 \\
(0.0176)\end{array}$ \\
\hline \multicolumn{6}{|c|}{ Broad region (reference cat.: Boarder, Midlands, West) } \\
\hline Dublin and Mid-East & $\begin{array}{c}-0.00336 \\
(0.0149)\end{array}$ & $\begin{array}{c}-0.00354 \\
(0.0157)\end{array}$ & $\begin{array}{l}-0.00261 \\
(0.0117)\end{array}$ & $\begin{array}{l}0.00420 \\
(0.0186)\end{array}$ & $\begin{array}{l}0.00530 \\
(0.0237)\end{array}$ \\
\hline Mid-West, South-East and South-West & $\begin{array}{l}0.00803 \\
(0.0149)\end{array}$ & $\begin{array}{c}0.00838 \\
(0.0154)\end{array}$ & $\begin{array}{l}0.00596 \\
(0.0107)\end{array}$ & $\begin{array}{l}-0.0100 \\
(0.0185)\end{array}$ & $\begin{array}{l}-0.0124 \\
(0.0224)\end{array}$ \\
\hline Tenure (reference cat.: Owner-occupied) & -0.0142 & -0.0152 & & & \\
\hline rented accomodation & $(0.0133)$ & $(0.0145)$ & $(0.0122)$ & $(0.0168)$ & $(0.0231)$ \\
\hline all other categories of tenure & $\begin{array}{l}-0.0499 \\
(0.0312)\end{array}$ & $\begin{array}{c}-0.0721^{*} \\
(0.0375)\end{array}$ & $\begin{array}{l}0.172 * * \\
(0.0806)\end{array}$ & $\begin{array}{c}0.0405 \\
(0.0773)\end{array}$ & $\begin{array}{c}-0.0906 * * \\
(0.0416)\end{array}$ \\
\hline Length of residence (reference cat.: Less than 5 & ears) & & & & \\
\hline $5-20$ years & $\begin{array}{l}0.00200 \\
(0.0228)\end{array}$ & $\begin{array}{l}-0.0335 \\
(0.0253)\end{array}$ & $\begin{array}{c}0.0824 * * \\
(0.0322)\end{array}$ & $\begin{array}{l}-0.0126 \\
(0.0350)\end{array}$ & $\begin{array}{l}-0.0383 \\
(0.0295)\end{array}$ \\
\hline More than 20 years & $\begin{array}{r}-0.00527 \\
(0.0170)\end{array}$ & $\begin{array}{r}-0.00554 \\
(0.0179)\end{array}$ & $\begin{array}{r}-0.00408 \\
(0.0132)\end{array}$ & $\begin{array}{l}0.00659 \\
(0.0213)\end{array}$ & $\begin{array}{l}0.00830 \\
(0.0269)\end{array}$ \\
\hline Area of residence (reference cat.: Rural) & & & & & \\
\hline Urban & $\begin{array}{l}0.00343 \\
(0.0163)\end{array}$ & $\begin{array}{l}0.00359 \\
(0.0170)\end{array}$ & $\begin{array}{l}0.00260 \\
(0.0121)\end{array}$ & $\begin{array}{r}-0.00429 \\
(0.0204)\end{array}$ & $\begin{array}{c}-0.00534 \\
(0.0252)\end{array}$ \\
\hline Internal variables: satisfaction with local planning pre & dures & & & & \\
\hline Satisfaction with local planning procedures (refe & nce cat.: $\mathrm{Sc}$ & sfied) & & & \\
\hline Unsatisfied & $\begin{array}{c}0.0538^{* * *} \\
(0.0174)\end{array}$ & $\begin{array}{c}0.0510 * * * \\
(0.0150)\end{array}$ & $\begin{array}{c}0.0251 * * * \\
(0.00613)\end{array}$ & $\begin{array}{c}-0.0629 * * * \\
(0.0187)\end{array}$ & $\begin{array}{c}-0.0671 * * * \\
(0.0171)\end{array}$ \\
\hline Internal variables: national energy policy preferences & & & & & \\
\hline Tradeoff env. vs. econ. & $\begin{array}{c}-0.0285^{* * *} \\
(0.00550)\end{array}$ & $\begin{array}{c}-0.0299^{* * *} \\
(0.00589)\end{array}$ & $\begin{array}{c}-0.0219^{* * *} \\
(0.00501)\end{array}$ & $\begin{array}{c}0.0356^{* * *} \\
(0.00707)\end{array}$ & $\begin{array}{c}0.0447^{* * *} \\
(0.00825)\end{array}$ \\
\hline Tradeoff rel. vs. econ. & 0.00867 & $0.0349 * * *$ & -0.00958 & $-0.0394^{* *}$ & 0.00539 \\
\hline Tradeoff soc. vs. econ. & $0.0276^{* * *}$ & -0.00892 & -0.0156 & 0.00528 & -0.00836 \\
\hline Tradeoff rel. vs. env. & $\begin{array}{r}(0.0106) \\
-0.00538\end{array}$ & $\begin{array}{l}(0.0132) \\
-0.00565\end{array}$ & $\begin{array}{r}(0.0154) \\
-0.00413\end{array}$ & $\begin{array}{c}(0.0159) \\
0.00672\end{array}$ & $\begin{array}{l}(0.0123) \\
0.00844\end{array}$ \\
\hline & $(0.00545)$ & $(0.00573)$ & $(0.00422)$ & $(0.00682)$ & $(0.00853)$ \\
\hline Tradeoff soc. vs. env. & -0.0145 & $0.0234^{*}$ & $0.0370 * * *$ & -0.0184 & $-0.0276^{* *}$ \\
\hline Tradeoff soc. vs. rel. & $\begin{array}{l}(0.00976) \\
-0.00598\end{array}$ & $\begin{array}{r}(0.0122) \\
-0.00629\end{array}$ & $\begin{array}{r}(0.0142) \\
-0.00460\end{array}$ & $\begin{array}{c}(0.0154) \\
0.00748\end{array}$ & $\begin{array}{l}(0.0125) \\
0.00939\end{array}$ \\
\hline & $(0.00600)$ & $(0.00629)$ & $(0.00463)$ & $(0.00750)$ & $(0.00938)$ \\
\hline Internal variables: technology-specific criteria and pre & rences & & & & \\
\hline Landscape & $\begin{array}{c}-0.00173 \\
(0.0924)\end{array}$ & $\begin{array}{c}-0.00182 \\
(0.0971)\end{array}$ & $\begin{array}{c}-0.00133 \\
(0.0710)\end{array}$ & $\begin{array}{c}0.00216 \\
(0.115)\end{array}$ & $\begin{array}{l}0.00271 \\
(0.145)\end{array}$ \\
\hline Local environment & $\begin{array}{l}0.271^{*} \\
(0.152)\end{array}$ & $\begin{array}{c}0.583^{* * *} \\
(0.180)\end{array}$ & $-1.164 * * *$ & $\begin{array}{c}0.243 \\
(0.216)\end{array}$ & $\begin{array}{l}0.0670 \\
(0.192)\end{array}$ \\
\hline Local employment & $-0.239^{*}$ & $\begin{array}{c}0.211 \\
(0.161)\end{array}$ & $\begin{array}{c}0.189 \\
(0.208)\end{array}$ & $\begin{array}{l}-0.320 \\
(0.213)\end{array}$ & $\begin{array}{c}0.160 \\
(0.172)\end{array}$ \\
\hline Sound & $\begin{array}{c}(0.133) \\
0.569^{* * *}\end{array}$ & $\begin{array}{l}(0.161) \\
-0.224\end{array}$ & $\begin{array}{c}(0.208) \\
0.249\end{array}$ & $\begin{array}{l}(0.213) \\
-0.325\end{array}$ & -0.269 \\
\hline & $(0.134)$ & $(0.166)$ & $(0.203)$ & $(0.213)$ & $(0.170)$ \\
\hline Local economy & -0.0954 & -0.100 & -0.0733 & 0.119 & 0.150 \\
\hline & $(0.0903)$ & $(0.0947)$ & $(0.0699)$ & $(0.113)$ & $(0.141)$ \\
\hline Health & $-0.214^{* *}$ & $-0.225^{* *}$ & $-0.164^{* *}$ & $0.267 * *$ & $0.335^{* *}$ \\
\hline & $(0.0905)$ & $(0.0954)$ & $(0.0723)$ & $(0.114)$ & $(0.140)$ \\
\hline Observations & 950 & 950 & 950 & 950 & 950 \\
\hline
\end{tabular}

Note: Standard errors in parentheses. ${ }^{* * *} p<0.01,{ }^{* *} p<0.05,{ }^{*} p<0.1$. 
Table 9: WTA wind-farm development under an energy cooperative

\begin{tabular}{|c|c|c|c|c|c|}
\hline External variables: socio-demographic characteristics & Unwilling & $\begin{array}{c}\text { Somewhat } \\
\text { unwilling }\end{array}$ & Neutral & $\begin{array}{c}\text { Somewhat } \\
\text { willing }\end{array}$ & Willing \\
\hline \multicolumn{6}{|l|}{ Age (reference cat.: Younger than 25) } \\
\hline \multirow[t]{2}{*}{$25-44$} & 0.0175 & 0.0137 & 0.0113 & -0.0192 & -0.0233 \\
\hline & $(0.0208)$ & $(0.0160)$ & $(0.0126)$ & $(0.0227)$ & $(0.0265)$ \\
\hline \multirow[t]{2}{*}{$45-59$} & 0.0283 & 0.0215 & 0.0165 & -0.0308 & -0.0355 \\
\hline & $(0.0239)$ & $(0.0175)$ & $(0.0116)$ & $(0.0256)$ & $(0.0271)$ \\
\hline \multirow[t]{2}{*}{60 or older } & 0.0246 & 0.0189 & 0.0148 & -0.0269 & -0.0314 \\
\hline & $(0.0293)$ & $(0.0217)$ & $(0.0153)$ & $(0.0315)$ & $(0.0345)$ \\
\hline \multicolumn{6}{|c|}{ Highest level of education (reference cat.: Primary school) } \\
\hline Leaving certificate & 0.00944 & 0.00741 & 0.00621 & -0.0104 & -0.0127 \\
\hline & $(0.0232)$ & $(0.0180)$ & $(0.0145)$ & $(0.0255)$ & $(0.0302)$ \\
\hline Post-secondary non-tertiary & 0.00680 & 0.00535 & 0.00451 & -0.00748 & -0.00917 \\
\hline & $(0.0240)$ & $(0.0187)$ & $(0.0152)$ & $(0.0264)$ & $(0.0315)$ \\
\hline Third level non-honours degree & 0.0228 & 0.0519 & $-0.115^{* * *}$ & 0.0274 & 0.0132 \\
\hline & $(0.0333)$ & $(0.0338)$ & $(0.0337)$ & $(0.0427)$ & $(0.0402)$ \\
\hline Third level honours or above & -0.0267 & -0.0221 & -0.0221 & 0.0292 & 0.0417 \\
\hline & $(0.0215)$ & $(0.0185)$ & $(0.0208)$ & $(0.0231)$ & $(0.0377)$ \\
\hline Income (reference cat.: Less than 15,000 ) & & & & & \\
\hline 15,000 to 30,000 & 0.00865 & 0.00682 & 0.00581 & -0.00952 & -0.0118 \\
\hline & $(0.0201)$ & $(0.0157)$ & $(0.0130)$ & $(0.0221)$ & $(0.0267)$ \\
\hline 30,000 to 50,000 & 0.00564 & 0.00445 & 0.00380 & -0.00621 & -0.00768 \\
\hline & $(0.0214)$ & $(0.0168)$ & $(0.0140)$ & $(0.0236)$ & $(0.0287)$ \\
\hline 50,000 to 75,000 & -0.0172 & -0.0141 & -0.0136 & 0.0189 & 0.0261 \\
\hline & $(0.0216)$ & $(0.0183)$ & $(0.0194)$ & $(0.0235)$ & $(0.0356)$ \\
\hline 75,000 or more & -0.00531 & -0.00427 & -0.00387 & 0.00586 & 0.00760 \\
\hline & $(0.0262)$ & $(0.0214)$ & $(0.0201)$ & $(0.0289)$ & $(0.0387)$ \\
\hline Employment (reference cat.: In employment) & & & & & \\
\hline Unemployed, student, home duties, other & -0.00110 & -0.000876 & -0.000767 & 0.00121 & 0.00153 \\
\hline & $(0.0154)$ & $(0.0122)$ & $(0.0108)$ & $(0.0170)$ & $(0.0214)$ \\
\hline Retired & 0.0211 & 0.0162 & 0.0127 & -0.0231 & -0.0270 \\
\hline & $(0.0248)$ & $(0.0184)$ & $(0.0129)$ & $(0.0268)$ & $(0.0292)$ \\
\hline Gender (reference cat.: Female) & & & & & \\
\hline Male & -0.0177 & -0.0141 & -0.0123 & 0.0195 & 0.0245 \\
\hline & $(0.0128)$ & $(0.0102)$ & $(0.00895)$ & $(0.0141)$ & $(0.0177)$ \\
\hline Broad region (reference cat.: Boarder, Midlands & West) & & & & \\
\hline Dublin and Mid-East & 0.0120 & 0.00942 & 0.00802 & -0.0132 & -0.0162 \\
\hline & $(0.0173)$ & $(0.0135)$ & $(0.0113)$ & $(0.0190)$ & $(0.0231)$ \\
\hline Mid-West, South-East and South-West & 0.00307 & 0.00243 & 0.00211 & -0.00338 & -0.00423 \\
\hline & $(0.0165)$ & $(0.0131)$ & $(0.0112)$ & $(0.0182)$ & $(0.0226)$ \\
\hline Tenure (reference cat.: Owner-occupied) & & & & & \\
\hline rented accomodation & 0.00309 & 0.00244 & 0.00211 & -0.00340 & -0.00424 \\
\hline & $(0.0161)$ & $(0.0127)$ & $(0.0108)$ & $(0.0178)$ & $(0.0219)$ \\
\hline all other categories of tenure & -0.0248 & -0.0209 & -0.0222 & 0.0269 & 0.0410 \\
\hline & $(0.0240)$ & $(0.0216)$ & $(0.0269)$ & $(0.0252)$ & $(0.0473)$ \\
\hline Length of residence (reference cat.: Less than 5 & ears) & & & & \\
\hline $5-20$ years & $0.0350^{*}$ & $0.0270^{*}$ & $0.0216^{*}$ & $-0.0381 *$ & $-0.0454^{*}$ \\
\hline & $(0.0202)$ & $(0.0151)$ & $(0.0113)$ & $(0.0217)$ & $(0.0245)$ \\
\hline More than 20 years & 0.0333 & $0.0465^{*}$ & $-0.0574 * *$ & 0.00158 & -0.0240 \\
\hline & $(0.0260)$ & $(0.0249)$ & $(0.0289)$ & $(0.0356)$ & $(0.0316)$ \\
\hline Area of residence (reference cat.: Rural) & & & & & \\
\hline Urban & -0.0145 & -0.0117 & -0.0106 & 0.0160 & 0.0208 \\
\hline & $(0.0177)$ & $(0.0144)$ & $(0.0136)$ & $(0.0195)$ & $(0.0262)$ \\
\hline Internal variables: satisfaction with local planning pro & dures & & & & \\
\hline Satisfaction with local planning procedures (refe & ence cat.: $\mathrm{S}$ & isfied) & & & \\
\hline Unsatisfied & $0.0991 * * *$ & 0.0154 & -0.0389 & $-0.0827^{* *}$ & 0.00716 \\
\hline & $(0.0293)$ & $(0.0269)$ & $(0.0326)$ & $(0.0356)$ & $(0.0301)$ \\
\hline Internal variables: national energy policy preferences & & & & & \\
\hline Tradeoff env. vs. econ. & $-0.0208^{* *}$ & $-0.0224^{* *}$ & $-0.0342^{* * *}$ & 0.0109 & $0.0665^{* * *}$ \\
\hline & $(0.00820)$ & $(0.00902)$ & $(0.0126)$ & $(0.0140)$ & $(0.0112)$ \\
\hline Tradeoff rel. vs. econ. & 0.00201 & 0.00160 & 0.00139 & -0.00221 & -0.00279 \\
\hline & $(0.00707)$ & $(0.00562)$ & $(0.00491)$ & $(0.00780)$ & $(0.00980)$ \\
\hline Tradeoff soc. vs. econ. & $0.0374^{* * *}$ & $0.0266^{* *}$ & $-0.0377^{* * *}$ & -0.0104 & -0.0159 \\
\hline & $(0.0105)$ & $(0.0117)$ & $(0.0117)$ & $(0.0161)$ & $(0.0124)$ \\
\hline Tradeoff rel. vs. env. & -0.000291 & -0.000231 & -0.000202 & 0.000320 & 0.000403 \\
\hline & $(0.00632)$ & $(0.00502)$ & $(0.00438)$ & $(0.00696)$ & $(0.00876)$ \\
\hline Tradeoff soc. vs. env. & -0.00839 & 0.000291 & $0.0367 * * *$ & -0.00697 & $-0.0216^{*}$ \\
\hline & $(0.0102)$ & $(0.0105)$ & $(0.0118)$ & $(0.0151)$ & $(0.0126)$ \\
\hline Tradeoff soc. vs. rel. & $-0.0160 * *$ & $-0.0127^{* *}$ & $-0.0111^{* *}$ & $0.0176^{* *}$ & $0.0222 * *$ \\
\hline & $(0.00701)$ & $(0.00561)$ & $(0.00502)$ & $(0.00781)$ & $(0.00963)$ \\
\hline Internal variables: technology-specific criteria and pre & rences & & & & \\
\hline Landscape & 0.0783 & 0.0622 & 0.0543 & -0.0863 & -0.109 \\
\hline & $(0.103)$ & $(0.0822)$ & $(0.0717)$ & $(0.114)$ & $(0.143)$ \\
\hline Local environment & $0.276^{*}$ & $0.240^{*}$ & $-1.044 * * *$ & $0.331^{*}$ & 0.196 \\
\hline & $(0.150)$ & $(0.146)$ & $(0.196)$ & $(0.201)$ & $(0.185)$ \\
\hline Local employment & 0.00370 & 0.00294 & 0.00256 & -0.00408 & -0.00513 \\
\hline & $(0.0948)$ & $(0.0753)$ & $(0.0657)$ & $(0.104)$ & $(0.131)$ \\
\hline Sound & $0.192^{* *}$ & $0.152^{* *}$ & $0.133^{* *}$ & $-0.211 * *$ & $-0.266 * *$ \\
\hline & $(0.0936)$ & $(0.0750)$ & $(0.0664)$ & $(0.104)$ & $(0.129)$ \\
\hline Local economy & $-0.185^{*}$ & $-0.147^{*}$ & $-0.128^{*}$ & $0.204^{*}$ & $0.257^{*}$ \\
\hline & $(0.102)$ & $(0.0814)$ & $(0.0726)$ & $(0.113)$ & $(0.141)$ \\
\hline Health & -0.0729 & -0.0580 & -0.0506 & 0.0804 & 0.101 \\
\hline & $(0.101)$ & $(0.0803)$ & $(0.0701)$ & $(0.111)$ & $(0.140)$ \\
\hline Observations & 956 & 956 & 956 & 956 & 956 \\
\hline
\end{tabular}

Note: Standard errors in parentheses. ${ }^{* * *} p<0.01,{ }^{* *} p<0.05,{ }^{*} p<0.1$. 
Table 10: WTA transmission-grid expansion under no involvement scheme

\begin{tabular}{|c|c|c|c|c|c|}
\hline External variables: socio-demographic characteristics & Unwilling & $\begin{array}{c}\text { Somewhat } \\
\text { unwilling }\end{array}$ & Neutral & $\begin{array}{c}\text { Somewhat } \\
\text { willing }\end{array}$ & Willing \\
\hline \multicolumn{6}{|l|}{ Age (reference cat.: Younger than 25) } \\
\hline $25-44$ & $\begin{array}{l}0.0729^{*} \\
(0.0390)\end{array}$ & $\begin{array}{c}0.0216^{* *} \\
(0.0102)\end{array}$ & $\begin{array}{c}-0.0374^{*} \\
(0.0204)\end{array}$ & $\begin{array}{c}-0.0349 * * \\
(0.0178)\end{array}$ & $\begin{array}{c}-0.0222^{* *} \\
(0.0112)\end{array}$ \\
\hline $45-59$ & $\begin{array}{l}0.205 * * * \\
(0.0474)\end{array}$ & $\begin{array}{c}0.0328 * * * \\
(0.00751)\end{array}$ & $\begin{array}{c}-0.106 * * * \\
(0.0248)\end{array}$ & $\begin{array}{c}-0.0819^{* * *} \\
(0.0163)\end{array}$ & $-0.0498^{* * *}$ \\
\hline 60 or older & $\begin{array}{c}(0.0474) \\
0.173 * * * \\
(0.0593)\end{array}$ & $\begin{array}{l}0.0337^{* * *} \\
(0.00747)\end{array}$ & $\begin{array}{c}(0.0248) \\
-0.0896 * * \\
(0.0307)\end{array}$ & $\begin{array}{c}(0.0163) \\
-0.0726^{* * *} \\
(0.0212)\end{array}$ & $\begin{array}{c}-0.0446 * * * \\
(0.0130)\end{array}$ \\
\hline \multicolumn{6}{|c|}{ Highest level of education (reference cat.: Primary school) } \\
\hline Leaving certificate & $\begin{array}{r}-0.00656 \\
(0.0410)\end{array}$ & $\begin{array}{r}-0.00228 \\
(0.0145)\end{array}$ & $\begin{array}{l}0.00329 \\
(0.0205)\end{array}$ & $\begin{array}{l}0.00336 \\
(0.0212)\end{array}$ & $\begin{array}{l}0.00219 \\
(0.0138)\end{array}$ \\
\hline Post-secondary non-tertiary & $\begin{array}{c}-0.00242 \\
(0.0431)\end{array}$ & $\begin{array}{c}-0.000833 \\
(0.0150)\end{array}$ & $\begin{array}{l}0.00122 \\
(0.0216)\end{array}$ & $\begin{array}{l}0.00124 \\
(0.0221)\end{array}$ & $\begin{array}{l}0.000801 \\
(0.0144)\end{array}$ \\
\hline Third level non-honours degree & $\begin{array}{l}-0.0340 \\
(0.0416)\end{array}$ & $\begin{array}{l}-0.0129 \\
(0.0175)\end{array}$ & $\begin{array}{c}0.0166 \\
(0.0196)\end{array}$ & $\begin{array}{c}0.0182 \\
(0.0235)\end{array}$ & $\begin{array}{c}0.0121 \\
(0.0160)\end{array}$ \\
\hline Third level honours or above & $\begin{array}{c}-0.00803 \\
(0.0444)\end{array}$ & $\begin{array}{r}-0.00282 \\
(0.0160)\end{array}$ & $\begin{array}{l}0.00402 \\
(0.0221)\end{array}$ & $\begin{array}{l}0.00414 \\
(0.0232)\end{array}$ & $\begin{array}{l}0.00269 \\
(0.0152)\end{array}$ \\
\hline \multicolumn{6}{|l|}{ Income (reference cat.: Less than 15,000 ) } \\
\hline 15,000 to 30,000 & $\begin{array}{c}0.0612 \\
(0.0383)\end{array}$ & $\begin{array}{l}0.0186^{*} \\
(0.0105)\end{array}$ & $\begin{array}{l}-0.0313 \\
(0.0200)\end{array}$ & $\begin{array}{c}-0.0296^{*} \\
(0.0177)\end{array}$ & $\begin{array}{c}-0.0188^{*} \\
(0.0112)\end{array}$ \\
\hline 30,000 to 50,000 & $\begin{array}{c}0.0568 \\
(0.0413)\end{array}$ & $\begin{array}{c}0.0168 \\
(0.0105)\end{array}$ & $\begin{array}{l}-0.0293 \\
(0.0217)\end{array}$ & $\begin{array}{l}-0.0272 \\
(0.0186)\end{array}$ & $\begin{array}{l}-0.0172 \\
(0.0116)\end{array}$ \\
\hline 50,000 to 75,000 & $\begin{array}{c}0.0796 \\
(0.0505)\end{array}$ & $\begin{array}{l}0.0194^{* *} \\
(0.00834)\end{array}$ & $\begin{array}{l}-0.0417 \\
(0.0272)\end{array}$ & $\begin{array}{l}-0.0355^{*} \\
(0.0198)\end{array}$ & $\begin{array}{l}-0.0219^{*} \\
(0.0118)\end{array}$ \\
\hline 75,000 or more & $\begin{array}{c}0.0579 \\
(0.0576)\end{array}$ & $\begin{array}{c}0.0150 \\
(0.0107)\end{array}$ & $\begin{array}{l}-0.0303 \\
(0.0310)\end{array}$ & $\begin{array}{l}-0.0263 \\
(0.0234)\end{array}$ & $\begin{array}{l}-0.0163 \\
(0.0140)\end{array}$ \\
\hline \multicolumn{6}{|l|}{ Employment (reference cat.: In employment) } \\
\hline Unemployed, student, home duties, other & $\begin{array}{c}0.0462 \\
(0.0299)\end{array}$ & $\begin{array}{c}0.0145^{*} \\
(0.00882)\end{array}$ & $\begin{array}{l}-0.0235 \\
(0.0155)\end{array}$ & $\begin{array}{l}-0.0227 \\
(0.0143)\end{array}$ & $\begin{array}{c}-0.0145 \\
(0.00905)\end{array}$ \\
\hline Retired & $\begin{array}{c}0.0296 \\
(0.0458)\end{array}$ & $\begin{array}{l}0.00920 \\
(0.0129)\end{array}$ & $\begin{array}{l}-0.0152 \\
(0.0239)\end{array}$ & $\begin{array}{l}-0.0144 \\
(0.0215)\end{array}$ & $\begin{array}{c}-0.00920 \\
(0.0134)\end{array}$ \\
\hline Gender (reference cat.: Female) & & & & & \\
\hline Male & $\begin{array}{l}-0.0119 \\
(0.0237)\end{array}$ & $\begin{array}{l}-0.00406 \\
(0.00813)\end{array}$ & $\begin{array}{l}0.00598 \\
(0.0120)\end{array}$ & $\begin{array}{l}0.00604 \\
(0.0121)\end{array}$ & $\begin{array}{c}0.00391 \\
(0.00783)\end{array}$ \\
\hline Broad region (reference cat.: Boarder, Midlands & West) & & & & \\
\hline Dublin and Mid-East & $\begin{array}{l}-0.0336 \\
(0.0308)\end{array}$ & $\begin{array}{l}-0.0120 \\
(0.0115)\end{array}$ & $\begin{array}{c}0.0167 \\
(0.0152)\end{array}$ & $\begin{array}{c}0.0174 \\
(0.0163)\end{array}$ & $\begin{array}{c}0.0114 \\
(0.0108)\end{array}$ \\
\hline Mid-West, South-East and South-West & $\begin{array}{l}-0.0319 \\
(0.0303)\end{array}$ & $\begin{array}{l}-0.0115 \\
(0.0115)\end{array}$ & $\begin{array}{c}0.0158 \\
(0.0148)\end{array}$ & $\begin{array}{c}0.0167 \\
(0.0162)\end{array}$ & $\begin{array}{c}0.0109 \\
(0.0108)\end{array}$ \\
\hline $\begin{array}{l}\text { Tenure (reference cat.: Owner-occupied) } \\
\text { rented accomodation }\end{array}$ & $\begin{array}{l}-0.0379 \\
(0.0283)\end{array}$ & $\begin{array}{l}-0.0141 \\
(0.0115)\end{array}$ & $\begin{array}{c}0.0186 \\
(0.0136)\end{array}$ & $\begin{array}{c}0.0201 \\
(0.0157)\end{array}$ & $\begin{array}{c}0.0133 \\
(0.0107)\end{array}$ \\
\hline all other categories of tenure & $\begin{array}{l}-0.0467 \\
(0.0486)\end{array}$ & $\begin{array}{l}-0.0200 \\
(0.0252)\end{array}$ & $\begin{array}{l}0.0217 \\
(0.0203)\end{array}$ & $\begin{array}{l}0.0266 \\
(0.0311)\end{array}$ & $\begin{array}{c}0.0183 \\
(0.0226)\end{array}$ \\
\hline Length of residence (reference cat.: Less than 5 & ears) & & & & \\
\hline $5-20$ years & $\begin{array}{c}-0.000905 \\
(0.0347)\end{array}$ & $\begin{array}{c}-0.000310 \\
(0.0119)\end{array}$ & $\begin{array}{c}0.000455 \\
(0.0175)\end{array}$ & $\begin{array}{c}0.000461 \\
(0.0177)\end{array}$ & $\begin{array}{c}0.000299 \\
(0.0115)\end{array}$ \\
\hline More than 20 years & $\begin{array}{l}-0.0111 \\
(0.0365)\end{array}$ & $\begin{array}{l}-0.00382 \\
(0.0126)\end{array}$ & $\begin{array}{l}0.00559 \\
(0.0183)\end{array}$ & $\begin{array}{l}0.00567 \\
(0.0186)\end{array}$ & $\begin{array}{l}0.00368 \\
(0.0121)\end{array}$ \\
\hline Area of residence (reference cat.: Rural) & & & & & \\
\hline Urban & $\begin{array}{c}0.0286 \\
(0.0353)\end{array}$ & $\begin{array}{l}0.00926 \\
(0.0109)\end{array}$ & $\begin{array}{l}-0.0145 \\
(0.0181)\end{array}$ & $\begin{array}{l}-0.0142 \\
(0.0171)\end{array}$ & $\begin{array}{r}-0.00911 \\
(0.0109)\end{array}$ \\
\hline Internal variables: satisfaction with local planning pro & edures & & & & \\
\hline Satisfaction with local planning procedures (refe & ence cat.: $\mathrm{S}$ & isfied) & & & \\
\hline Unsatisfied & $\begin{array}{c}0.157 * * * \\
(0.0315)\end{array}$ & $\begin{array}{c}0.0317 * * * \\
(0.00649)\end{array}$ & $\begin{array}{c}-0.0814^{* * *} \\
(0.0175)\end{array}$ & $\begin{array}{c}-0.0663^{* * *} \\
(0.0120)\end{array}$ & $\begin{array}{r}-0.0407 * * * \\
(0.00766)\end{array}$ \\
\hline Internal variables: national energy policy preferences & & & & & \\
\hline Tradeoff env. vs. econ. & $\begin{array}{c}-0.0239^{* *} \\
(0.0108)\end{array}$ & $\begin{array}{c}-0.00816^{* *} \\
(0.00385)\end{array}$ & $\begin{array}{l}0.0120^{* *} \\
(0.00556)\end{array}$ & $\begin{array}{l}0.0122^{* *} \\
(0.00557)\end{array}$ & $\begin{array}{c}0.00787^{* *} \\
(0.00363)\end{array}$ \\
\hline Tradeoff rel. vs. econ. & $\begin{array}{l}0.00208 \\
(0.0133)\end{array}$ & $\begin{array}{l}0.000712 \\
(0.00454)\end{array}$ & $\begin{array}{l}-0.00105 \\
(0.00669)\end{array}$ & $\begin{array}{l}-0.00106 \\
(0.00676)\end{array}$ & $\begin{array}{r}-0.000687 \\
(0.00438)\end{array}$ \\
\hline Tradeoff soc. vs. econ. & $0.0223^{*}$ & $0.00762^{*}$ & $-0.0112^{*}$ & $-0.0113^{*}$ & $-0.00735^{*}$ \\
\hline & $(0.0128)$ & $(0.00447)$ & $(0.00651)$ & $(0.00655)$ & $(0.00426)$ \\
\hline Tradeoff rel. vs. env. & $-0.0215^{*}$ & $-0.00736^{*}$ & $0.0108^{*}$ & $0.0109 *$ & $0.00709 *$ \\
\hline & $(0.0121)$ & $(0.00426)$ & $(0.00619)$ & $(0.00621)$ & $(0.00404)$ \\
\hline Tradeoff soc. vs. env. & 0.0114 & 0.00390 & -0.00574 & -0.00580 & -0.00376 \\
\hline & $(0.0139)$ & $(0.00479)$ & $(0.00703)$ & $(0.00709)$ & $(0.00459)$ \\
\hline Tradeoff soc. vs. rel. & -0.0153 & -0.00524 & 0.00771 & 0.00779 & 0.00505 \\
\hline & $(0.0129)$ & $(0.00446)$ & $(0.00653)$ & $(0.00658)$ & $(0.00426)$ \\
\hline Internal variables: technology-specific criteria and pre & rences & & & & \\
\hline Landscape & $\begin{array}{c}0.275 \\
(0.197)\end{array}$ & $\begin{array}{c}0.0942 \\
(0.0682)\end{array}$ & $\begin{array}{c}-0.139 \\
(0.0998)\end{array}$ & $\begin{array}{l}-0.140 \\
(0.101)\end{array}$ & $\begin{array}{l}-0.0908 \\
(0.0653)\end{array}$ \\
\hline Local environment & $\begin{array}{l}0.0594 \\
(0.219)\end{array}$ & $\begin{array}{c}0.0203 \\
(0.0747)\end{array}$ & $\begin{array}{c}-0.0299 \\
(0.110)\end{array}$ & $\begin{array}{c}-0.0302 \\
(0.111)\end{array}$ & $\begin{array}{l}-0.0196 \\
(0.0720)\end{array}$ \\
\hline Local employment & -0.181 & -0.0618 & 0.0909 & 0.0919 & 0.0595 \\
\hline & $(0.177)$ & $(0.0609)$ & $(0.0893)$ & $(0.0902)$ & $(0.0585)$ \\
\hline Sound & 0.192 & 0.0657 & -0.0967 & -0.0978 & -0.0633 \\
\hline & $(0.174)$ & $(0.0600)$ & $(0.0881)$ & $(0.0888)$ & $(0.0576)$ \\
\hline Local economy & 0.00514 & 0.00176 & -0.00259 & -0.00261 & -0.00169 \\
\hline & $(0.187)$ & $(0.0639)$ & $(0.0940)$ & $(0.0951)$ & $(0.0616)$ \\
\hline Health & -0.156 & -0.0534 & 0.0786 & 0.0794 & 0.0514 \\
\hline & $(0.196)$ & $(0.0672)$ & $(0.0987)$ & $(0.0997)$ & $(0.0646)$ \\
\hline Safety & 0.209 & 0.0713 & -0.105 & -0.106 & -0.0688 \\
\hline & $(0.164)$ & $(0.0570)$ & $(0.0834)$ & $(0.0840)$ & $(0.0545)$ \\
\hline Observations & 940 & 940 & 940 & 940 & 940 \\
\hline
\end{tabular}


Table 11: WTA transmission-grid expansion under a community benefit scheme

\begin{tabular}{|c|c|c|c|c|c|}
\hline External variables: socio-demographic characteristics & Unwilling & $\begin{array}{c}\text { Somewhat } \\
\text { unwilling }\end{array}$ & Neutral & $\begin{array}{c}\text { Somewhat } \\
\text { willing }\end{array}$ & Willing \\
\hline \multicolumn{6}{|l|}{ Age (reference cat.: Younger than 25) } \\
\hline $25-44$ & $\begin{array}{c}0.0484^{* *} \\
(0.0219)\end{array}$ & $\begin{array}{c}0.0350^{* *} \\
(0.0151)\end{array}$ & $\begin{array}{c}0.0342^{* * * *} \\
(0.0133)\end{array}$ & $\begin{array}{c}-0.0554^{* *} \\
(0.0248)\end{array}$ & $\begin{array}{c}-0.0622^{* *} \\
(0.0249)\end{array}$ \\
\hline $45-59$ & $\begin{array}{c}0.105 * * * \\
(0.0299)\end{array}$ & $\begin{array}{c}0.0675 * * * \\
(0.0165)\end{array}$ & $\begin{array}{c}0.0501 * * * \\
(0.00922)\end{array}$ & $\begin{array}{c}-0.115^{* * *} \\
(0.0298)\end{array}$ & $\begin{array}{c}-0.108^{* * *} \\
(0.0221)\end{array}$ \\
\hline 60 or older & $\begin{array}{l}0.107 * * * \\
(0.0375)\end{array}$ & $\begin{array}{c}0.0690 * * * \\
(0.0204)\end{array}$ & $\begin{array}{c}0.0522^{* * *} \\
(0.0106)\end{array}$ & $\begin{array}{c}-0.117^{* * *} \\
(0.0370)\end{array}$ & $\begin{array}{c}-0.111^{* * *} * \\
(0.0284)\end{array}$ \\
\hline \multicolumn{6}{|c|}{ Highest level of education (reference cat.: Primary school) } \\
\hline Leaving certificate & $\begin{array}{l}-0.0265 \\
(0.0195)\end{array}$ & $\begin{array}{l}-0.0207 \\
(0.0158)\end{array}$ & $\begin{array}{l}-0.0245 \\
(0.0200)\end{array}$ & $\begin{array}{c}0.0297 \\
(0.0212)\end{array}$ & $\begin{array}{c}0.0420 \\
(0.0340)\end{array}$ \\
\hline Post-secondary non-tertiary & $\begin{array}{l}-0.0129 \\
(0.0212)\end{array}$ & $\begin{array}{l}-0.0100 \\
(0.0167)\end{array}$ & $\begin{array}{l}-0.0115 \\
(0.0200)\end{array}$ & $\begin{array}{c}0.0147 \\
(0.0238)\end{array}$ & $\begin{array}{c}0.0197 \\
(0.0341)\end{array}$ \\
\hline Third level non-honours degree & $\begin{array}{c}-0.0345^{*} \\
(0.0193)\end{array}$ & $\begin{array}{c}-0.0275^{*} \\
(0.0162)\end{array}$ & $\begin{array}{l}-0.0343 \\
(0.0225)\end{array}$ & $\begin{array}{l}0.0377^{*} \\
(0.0196)\end{array}$ & $\begin{array}{c}0.0587 \\
(0.0384)\end{array}$ \\
\hline Third level honours or above & $\begin{array}{c}-0.0415^{* *} \\
(0.0191)\end{array}$ & $\begin{array}{c}-0.0333^{* *} \\
(0.0162)\end{array}$ & $\begin{array}{l}-0.0424^{*} \\
(0.0235)\end{array}$ & $\begin{array}{c}0.0444^{* *} \\
(0.0184)\end{array}$ & $\begin{array}{l}0.0728^{*} \\
(0.0404)\end{array}$ \\
\hline \multicolumn{6}{|l|}{ Income (reference cat.: Less than 15,000 ) } \\
\hline 15,000 to 30,000 & $\begin{array}{l}0.00315 \\
(0.0190)\end{array}$ & $\begin{array}{l}0.00238 \\
(0.0144)\end{array}$ & $\begin{array}{l}0.00259 \\
(0.0155)\end{array}$ & $\begin{array}{c}-0.00362 \\
(0.0219)\end{array}$ & $\begin{array}{r}-0.00449 \\
(0.0269)\end{array}$ \\
\hline 30,000 to 50,000 & $\begin{array}{c}0.0207 \\
(0.0217)\end{array}$ & $\begin{array}{c}0.0153 \\
(0.0157)\end{array}$ & $\begin{array}{c}0.0157 \\
(0.0151)\end{array}$ & $\begin{array}{l}-0.0239 \\
(0.0252)\end{array}$ & $\begin{array}{l}-0.0278 \\
(0.0272)\end{array}$ \\
\hline 50,000 to 75,000 & $\begin{array}{c}-0.00679 \\
(0.0223)\end{array}$ & $\begin{array}{c}-0.00522 \\
(0.0173)\end{array}$ & $\begin{array}{l}-0.00589 \\
(0.0202)\end{array}$ & $\begin{array}{l}0.00777 \\
(0.0253)\end{array}$ & $\begin{array}{c}0.0101 \\
(0.0345)\end{array}$ \\
\hline 75,000 or more & $\begin{array}{c}0.0193 \\
(0.0425)\end{array}$ & $\begin{array}{c}0.0421 \\
(0.0433)\end{array}$ & $\begin{array}{l}-0.103^{* *} \\
(0.0412)\end{array}$ & $\begin{array}{l}-0.00743 \\
(0.0587)\end{array}$ & $\begin{array}{c}0.0488 \\
(0.0543)\end{array}$ \\
\hline \multicolumn{6}{|l|}{ Employment (reference cat.: In employment) } \\
\hline Unemployed, student, home duties, other & $\begin{array}{c}0.0127 \\
(0.0155)\end{array}$ & $\begin{array}{l}0.00956 \\
(0.0115)\end{array}$ & $\begin{array}{c}0.0102 \\
(0.0119)\end{array}$ & $\begin{array}{l}-0.0147 \\
(0.0179)\end{array}$ & $\begin{array}{l}-0.0178 \\
(0.0209)\end{array}$ \\
\hline Retired & $\begin{array}{l}-0.00361 \\
(0.0219)\end{array}$ & $\begin{array}{c}-0.00275 \\
(0.0168)\end{array}$ & $\begin{array}{c}-0.00305 \\
(0.0189)\end{array}$ & $\begin{array}{l}0.00414 \\
(0.0251)\end{array}$ & $\begin{array}{l}0.00527 \\
(0.0325)\end{array}$ \\
\hline \multicolumn{6}{|l|}{ Gender (reference cat.: Female) } \\
\hline Male & $\begin{array}{l}0.00574 \\
(0.0124)\end{array}$ & $\begin{array}{c}0.00436 \\
(0.00942)\end{array}$ & $\begin{array}{l}0.00476 \\
(0.0103)\end{array}$ & $\begin{array}{c}-0.00660 \\
(0.0143)\end{array}$ & $\begin{array}{r}-0.00825 \\
(0.0178)\end{array}$ \\
\hline Broad region (reference cat.: Boarder, Midlands, & West) & & & & \\
\hline Dublin and Mid-East & $\begin{array}{l}0.00522 \\
(0.0165)\end{array}$ & $\begin{array}{l}0.00395 \\
(0.0124)\end{array}$ & $\begin{array}{l}0.00428 \\
(0.0133)\end{array}$ & $\begin{array}{l}-0.00601 \\
(0.0190)\end{array}$ & $\begin{array}{r}-0.00743 \\
(0.0232)\end{array}$ \\
\hline Mid-West, South-East and South-West & $\begin{array}{c}0.0210 \\
(0.0170)\end{array}$ & $\begin{array}{c}0.0156 \\
(0.0125)\end{array}$ & $\begin{array}{c}0.0164 \\
(0.0126)\end{array}$ & $\begin{array}{l}-0.0242 \\
(0.0197)\end{array}$ & $\begin{array}{l}-0.0288 \\
(0.0223)\end{array}$ \\
\hline $\begin{array}{l}\text { Tenure (reference cat.: Owner-occupied) } \\
\text { rented accomodation }\end{array}$ & $\begin{array}{l}-0.0230 \\
(0.0143)\end{array}$ & $\begin{array}{l}-0.0179 \\
(0.0114)\end{array}$ & $\begin{array}{l}-0.0208 \\
(0.0141)\end{array}$ & $\begin{array}{c}0.0259 \\
(0.0158)\end{array}$ & $\begin{array}{c}0.0357 \\
(0.0239)\end{array}$ \\
\hline all other categories of tenure & $\begin{array}{l}0.0110 \\
(0.0301)\end{array}$ & $\begin{array}{l}0.00810 \\
(0.0217)\end{array}$ & $\begin{array}{l}0.00829 \\
(0.0207)\end{array}$ & $\begin{array}{l}-0.0127 \\
(0.0351)\end{array}$ & $\begin{array}{l}-0.0146 \\
(0.0374)\end{array}$ \\
\hline Length of residence (reference cat.: Less than 5 & ears) & & & & \\
\hline 5 - 20 years & $\begin{array}{c}-0.000461 \\
(0.0179)\end{array}$ & $\begin{array}{l}-0.000350 \\
(0.0136)\end{array}$ & $\begin{array}{c}-0.000384 \\
(0.0149)\end{array}$ & $\begin{array}{c}0.000531 \\
(0.0206)\end{array}$ & $\begin{array}{c}0.000664 \\
(0.0259)\end{array}$ \\
\hline More than 20 years & $\begin{array}{r}-0.00600 \\
(0.0189)\end{array}$ & $\begin{array}{r}-0.00456 \\
(0.0144)\end{array}$ & $\begin{array}{r}-0.00500 \\
(0.0158)\end{array}$ & $\begin{array}{l}0.00690 \\
(0.0217)\end{array}$ & $\begin{array}{l}0.00866 \\
(0.0273)\end{array}$ \\
\hline Area of residence (reference cat.: Rural) & & & & & \\
\hline Urban & $\begin{array}{c}-0.00908 \\
(0.0176)\end{array}$ & $\begin{array}{c}-0.00694 \\
(0.0136)\end{array}$ & $\begin{array}{c}-0.00774 \\
(0.0154)\end{array}$ & $\begin{array}{c}0.0104 \\
(0.0201)\end{array}$ & $\begin{array}{c}0.0134 \\
(0.0265)\end{array}$ \\
\hline Internal variables: satisfaction with local planning pro & edures & & & & \\
\hline Satisfaction with local planning procedures (refe & ence cat.: $\mathrm{S}$ & isfied) & & & \\
\hline Unsatisfied & $\begin{array}{c}0.122 * * * \\
(0.0283)\end{array}$ & $\begin{array}{c}0.0788^{* * *} \\
(0.0269)\end{array}$ & $\begin{array}{c}-0.0737^{* *} \\
(0.0290)\end{array}$ & $\begin{array}{c}-0.107^{* * *} * \\
(0.0361)\end{array}$ & $\begin{array}{l}-0.0202 \\
(0.0278)\end{array}$ \\
\hline Internal variables: national energy policy preferences & & & & & \\
\hline Tradeoff env. vs. econ. & $\begin{array}{l}-0.0107^{*} \\
(0.00569)\end{array}$ & $\begin{array}{l}-0.00811^{*} \\
(0.00436)\end{array}$ & $\begin{array}{c}-0.00887^{*} \\
(0.00479)\end{array}$ & $\begin{array}{l}0.0123^{*} \\
(0.00661)\end{array}$ & $\begin{array}{c}0.0154^{*} \\
(0.00816)\end{array}$ \\
\hline Tradeoff rel. vs. econ. & $\begin{array}{c}0.00294 \\
(0.00941)\end{array}$ & $\begin{array}{l}-0.00175 \\
(0.00927)\end{array}$ & $\begin{array}{c}-0.0449^{* * *} \\
(0.0122)\end{array}$ & $\begin{array}{c}0.0154 \\
(0.0154)\end{array}$ & $\begin{array}{c}0.0284^{* *} \\
(0.0122)\end{array}$ \\
\hline Tradeoff soc. vs. econ. & $\begin{array}{l}0.00417 \\
(0.00647)\end{array}$ & $\begin{array}{c}0.00316 \\
(0.00492)\end{array}$ & $\begin{array}{c}0.00346 \\
(0.00538)\end{array}$ & $\begin{array}{l}-0.00480 \\
(0.00745)\end{array}$ & $\begin{array}{l}-0.00599 \\
(0.00930)\end{array}$ \\
\hline Tradeoff rel. vs. env. & $\begin{array}{l}-0.00853 \\
(0.00618)\end{array}$ & $\begin{array}{l}-0.00647 \\
(0.00471)\end{array}$ & $\begin{array}{l}-0.00708 \\
(0.00518)\end{array}$ & $\begin{array}{c}0.00982 \\
(0.00714)\end{array}$ & $\begin{array}{c}0.0123 \\
(0.00888)\end{array}$ \\
\hline Tradeoff soc. vs. env. & $0.0131 *$ & $0.00997^{*}$ & $0.0109^{*}$ & $-0.0151^{*}$ & $-0.0189^{*}$ \\
\hline & $(0.00724)$ & $(0.00554)$ & $(0.00611)$ & $(0.00842)$ & $(0.0104)$ \\
\hline Tradeoff soc. vs. rel. & -0.000694 & -0.000527 & -0.000576 & 0.000799 & 0.000998 \\
\hline Internal variables: technology-specific criteria and pref & $\begin{array}{l}(0.00676) \\
\text { rences }\end{array}$ & $(0.00513)$ & $(0.00561)$ & $(0.00779)$ & \\
\hline Landscape & 0.160 & 0.122 & 0.133 & -0.184 & -0.230 \\
\hline & $(0.103)$ & $(0.0787)$ & $(0.0865)$ & $(0.119)$ & $(0.148)$ \\
\hline Local environment & $-0.238^{* *}$ & $-0.181^{* *}$ & $-0.198^{* * *}$ & $0.274^{* *}$ & $0.343^{* *}$ \\
\hline & $(0.116)$ & $(0.0885)$ & $(0.0979)$ & $(0.135)$ & $(0.166)$ \\
\hline Local employment & 0.101 & $0.240^{*}$ & 0.198 & $-0.989 * * *$ & $0.450^{* * *}$ \\
\hline & $(0.130)$ & $(0.133)$ & $(0.181)$ & $(0.226)$ & $(0.174)$ \\
\hline Sound & $0.147^{*}$ & 0.112 & 0.122 & -0.169 & $-0.211^{*}$ \\
\hline & $(0.0892)$ & $(0.0682)$ & $(0.0749)$ & $(0.103)$ & $(0.128)$ \\
\hline Local economy & 0.0178 & 0.0135 & 0.0148 & -0.0205 & -0.0256 \\
\hline & $(0.0983)$ & $(0.0746)$ & $(0.0816)$ & $(0.113)$ & $(0.141)$ \\
\hline Health & -0.0536 & -0.113 & $-0.942 * * *$ & $1.004^{* * *}$ & 0.105 \\
\hline & $(0.142)$ & $(0.138)$ & $(0.193)$ & $(0.219)$ & $(0.189)$ \\
\hline Safety & -0.105 & -0.0795 & -0.0869 & 0.121 & 0.151 \\
\hline & $(0.0874)$ & $(0.0665)$ & $(0.0730)$ & $(0.101)$ & $(0.126)$ \\
\hline Observations & 957 & 957 & 957 & 957 & 957 \\
\hline
\end{tabular}


Table 12: WTA transmission-grid expansion under equity involvement

\begin{tabular}{|c|c|c|c|c|c|}
\hline External variables: socio-demographic characteristics & Unwilling & $\begin{array}{l}\text { Somewhat } \\
\text { unwilling }\end{array}$ & Neutral & $\begin{array}{c}\text { Somewhat } \\
\text { willing }\end{array}$ & Willing \\
\hline \multicolumn{6}{|l|}{ Age (reference cat.: Younger than 25) } \\
\hline $25-44$ & $\begin{array}{c}0.0780 \\
(0.0484)\end{array}$ & $\begin{array}{c}0.0449 \\
(0.0577)\end{array}$ & $\begin{array}{c}-0.161 * * * \\
(0.0547)\end{array}$ & $\begin{array}{l}0.00976 \\
(0.0461)\end{array}$ & $\begin{array}{c}0.0282 \\
(0.0396)\end{array}$ \\
\hline \multirow[t]{2}{*}{$45-59$} & $0.169 * * *$ & 0.0278 & $-0.186^{* * *}$ & -0.0518 & 0.0413 \\
\hline & $(0.0645)$ & $(0.0669)$ & $(0.0579)$ & $(0.0457)$ & $(0.0433)$ \\
\hline 60 or older & $\begin{array}{c}0.216 * * * \\
(0.0737)\end{array}$ & $\begin{array}{c}0.0294 \\
(0.0693)\end{array}$ & $\begin{array}{c}-0.237^{* * *} \\
(0.0568)\end{array}$ & $\begin{array}{l}-0.0284 \\
(0.0482)\end{array}$ & $\begin{array}{c}0.0204 \\
(0.0440)\end{array}$ \\
\hline \multicolumn{6}{|c|}{ Highest level of education (reference cat.: Primary school) } \\
\hline Leaving certificate & $\begin{array}{l}-0.0240 \\
(0.0197)\end{array}$ & $\begin{array}{l}-0.0371 \\
(0.0319)\end{array}$ & $\begin{array}{c}0.00423 \\
(0.00283)\end{array}$ & $\begin{array}{c}0.0286 \\
(0.0244)\end{array}$ & $\begin{array}{c}0.0283 \\
(0.0255)\end{array}$ \\
\hline Post-secondary non-tertiary & $\begin{array}{c}-0.00168 \\
(0.0223)\end{array}$ & $\begin{array}{l}-0.00247 \\
(0.0330)\end{array}$ & $\begin{array}{l}0.000424 \\
(0.00550)\end{array}$ & $\begin{array}{l}0.00192 \\
(0.0256)\end{array}$ & $\begin{array}{l}0.00181 \\
(0.0242)\end{array}$ \\
\hline Third level non-honours degree & $\begin{array}{l}-0.0332^{*} \\
(0.0194)\end{array}$ & $\begin{array}{l}-0.0534 \\
(0.0337)\end{array}$ & $\begin{array}{c}0.00341 \\
(0.00362)\end{array}$ & $\begin{array}{c}0.0409 \\
(0.0255)\end{array}$ & $\begin{array}{c}0.0423 \\
(0.0291)\end{array}$ \\
\hline Third level honours or above & $\begin{array}{c}-0.0407 * * \\
(0.0190)\end{array}$ & $\begin{array}{l}-0.0665^{*} \\
(0.0339)\end{array}$ & $\begin{array}{c}0.00264 \\
(0.00517)\end{array}$ & $\begin{array}{c}0.0508^{* *} \\
(0.0255)\end{array}$ & $\begin{array}{l}0.0538^{*} \\
(0.0307)\end{array}$ \\
\hline \multicolumn{6}{|l|}{ Income (reference cat.: Less than 15,000 ) } \\
\hline 15,000 to 30,000 & $\begin{array}{c}-0.0347^{* *} \\
(0.0175)\end{array}$ & $\begin{array}{c}-0.0533^{*} \\
(0.0279)\end{array}$ & $\begin{array}{l}0.00615^{*} \\
(0.00357)\end{array}$ & $\begin{array}{l}0.0411 * \\
(0.0214)\end{array}$ & $\begin{array}{l}0.0408^{*} \\
(0.0225)\end{array}$ \\
\hline 30,000 to 50,000 & $\begin{array}{l}-0.0203 \\
(0.0186)\end{array}$ & $\begin{array}{l}-0.0311 \\
(0.0297)\end{array}$ & $\begin{array}{c}0.00393 \\
(0.00294)\end{array}$ & $\begin{array}{l}0.0240 \\
(0.0229)\end{array}$ & $\begin{array}{c}0.0235 \\
(0.0233)\end{array}$ \\
\hline 50,000 to 75,000 & $\begin{array}{l}-0.0252 \\
(0.0196)\end{array}$ & $\begin{array}{l}-0.0401 \\
(0.0338)\end{array}$ & $\begin{array}{c}0.00313 \\
(0.00255)\end{array}$ & $\begin{array}{l}0.0308 \\
(0.0257)\end{array}$ & $\begin{array}{c}0.0313 \\
(0.0284)\end{array}$ \\
\hline 75,000 or more & $\begin{array}{c}-0.00502 \\
(0.0250)\end{array}$ & $\begin{array}{c}-0.00751 \\
(0.0381)\end{array}$ & $\begin{array}{c}0.00116 \\
(0.00511)\end{array}$ & $\begin{array}{l}0.00582 \\
(0.0294)\end{array}$ & $\begin{array}{l}0.00555 \\
(0.0285)\end{array}$ \\
\hline \multicolumn{6}{|l|}{ Employment (reference cat.: In employment) } \\
\hline Unemployed, student, home duties, other & $\begin{array}{c}0.0110 \\
(0.0152)\end{array}$ & $\begin{array}{c}0.0159 \\
(0.0215)\end{array}$ & $\begin{array}{l}-0.00309 \\
(0.00468)\end{array}$ & $\begin{array}{l}-0.0124 \\
(0.0168)\end{array}$ & $\begin{array}{l}-0.0115 \\
(0.0154)\end{array}$ \\
\hline Retired & $\begin{array}{l}-0.0157 \\
(0.0203)\end{array}$ & $\begin{array}{l}-0.0241 \\
(0.0323)\end{array}$ & $\begin{array}{c}0.00309 \\
(0.00296)\end{array}$ & $\begin{array}{c}0.0186 \\
(0.0248)\end{array}$ & $\begin{array}{c}0.0181 \\
(0.0252)\end{array}$ \\
\hline \multicolumn{6}{|l|}{ Gender (reference cat.: Female) } \\
\hline Male & $\begin{array}{l}-0.0130 \\
(0.0193)\end{array}$ & $\begin{array}{c}0.0479 \\
(0.0295)\end{array}$ & $\begin{array}{c}-0.0585^{*} \\
(0.0312)\end{array}$ & $\begin{array}{l}0.0492 * \\
(0.0257)\end{array}$ & $\begin{array}{l}-0.0256 \\
(0.0207)\end{array}$ \\
\hline Broad region (reference cat.: Boarder, Midlands & West) & & & & \\
\hline Dublin and Mid-East & $\begin{array}{l}-0.0176 \\
(0.0158)\end{array}$ & $\begin{array}{l}-0.0262 \\
(0.0240)\end{array}$ & $\begin{array}{c}0.00403 \\
(0.00352)\end{array}$ & $\begin{array}{c}0.0203 \\
(0.0186)\end{array}$ & $\begin{array}{c}0.0194 \\
(0.0181)\end{array}$ \\
\hline Mid-West, South-East and South-West & $\begin{array}{c}0.0220 \\
(0.0225)\end{array}$ & $\begin{array}{c}0.0212 \\
(0.0333)\end{array}$ & $\begin{array}{c}-0.0578^{*} \\
(0.0330)\end{array}$ & $\begin{array}{l}-0.0383 \\
(0.0284)\end{array}$ & $\begin{array}{c}0.0529^{* *} \\
(0.0268)\end{array}$ \\
\hline $\begin{array}{l}\text { Tenure (reference cat.: Owner-occupied) } \\
\text { rented accomodation }\end{array}$ & $\begin{array}{l}-0.0191 \\
(0.0229)\end{array}$ & $\begin{array}{c}0.0211 \\
(0.0364)\end{array}$ & $\begin{array}{l}-0.0122 \\
(0.0352)\end{array}$ & $\begin{array}{l}0.0716^{* *} \\
(0.0323)\end{array}$ & $\begin{array}{c}-0.0614^{* * *} \\
(0.0223)\end{array}$ \\
\hline all other categories of tenure & $\begin{array}{l}0.00860 \\
(0.0307)\end{array}$ & $\begin{array}{c}0.0121 \\
(0.0417)\end{array}$ & $\begin{array}{c}-0.00263 \\
(0.0107)\end{array}$ & $\begin{array}{c}-0.00946 \\
(0.0326)\end{array}$ & $\begin{array}{r}-0.00865 \\
(0.0290)\end{array}$ \\
\hline Length of residence (reference cat.: Less than 5 & ears) & & & & \\
\hline $5-20$ years & $\begin{array}{c}0.0124 \\
(0.0184)\end{array}$ & $\begin{array}{l}0.0178 \\
(0.0260)\end{array}$ & $\begin{array}{l}-0.00346 \\
(0.00561)\end{array}$ & $\begin{array}{l}-0.0139 \\
(0.0203)\end{array}$ & $\begin{array}{l}-0.0129 \\
(0.0186)\end{array}$ \\
\hline More than 20 years & $\begin{array}{l}-0.0192 \\
(0.0186)\end{array}$ & $\begin{array}{l}-0.0284 \\
(0.0276)\end{array}$ & $\begin{array}{l}0.00476 \\
(0.00470)\end{array}$ & $\begin{array}{l}0.0220 \\
(0.0214)\end{array}$ & $\begin{array}{l}0.0208 \\
(0.0204)\end{array}$ \\
\hline Area of residence (reference cat.: Rural) & & & & & \\
\hline Urban & $\begin{array}{l}0.00924 \\
(0.0182)\end{array}$ & $\begin{array}{c}0.0133 \\
(0.0258)\end{array}$ & $\begin{array}{l}-0.00256 \\
(0.00540)\end{array}$ & $\begin{array}{l}-0.0104 \\
(0.0201)\end{array}$ & $\begin{array}{c}-0.00965 \\
(0.0185)\end{array}$ \\
\hline Internal variables: satisfaction with local planning pro & edures & & & & \\
\hline Satisfaction with local planning procedures (refe & ence cat.: $\mathrm{S}$ & sfied) & & & \\
\hline Unsatisfied & $\begin{array}{c}0.0823^{* * *} \\
(0.0268)\end{array}$ & $\begin{array}{c}-0.102 * * * \\
(0.0314)\end{array}$ & $\begin{array}{c}0.0157 \\
(0.0335)\end{array}$ & $\begin{array}{l}-0.0341 \\
(0.0285)\end{array}$ & $\begin{array}{c}0.0378 \\
(0.0258)\end{array}$ \\
\hline Internal variables: national energy policy preferences & & & & & \\
\hline Tradeoff env. vs. econ. & $\begin{array}{l}-0.0147^{*} \\
(0.00810)\end{array}$ & $\begin{array}{c}-0.0246^{*} \\
(0.0128)\end{array}$ & $\begin{array}{c}0.0198 \\
(0.0128)\end{array}$ & $\begin{array}{c}0.0269^{* * *} \\
(0.0101)\end{array}$ & $\begin{array}{l}-0.00740 \\
(0.00834)\end{array}$ \\
\hline Tradeoff rel. vs. econ. & $\begin{array}{r}-0.000989 \\
(0.00675)\end{array}$ & $\begin{array}{l}-0.00145 \\
(0.00990)\end{array}$ & $\begin{array}{l}0.000256 \\
(0.00175)\end{array}$ & $\begin{array}{c}0.00113 \\
(0.00768)\end{array}$ & $\begin{array}{c}0.00106 \\
(0.00722)\end{array}$ \\
\hline Tradeoff soc. vs. econ. & $\begin{array}{c}0.00711 \\
(0.00645)\end{array}$ & $\begin{array}{c}0.0104 \\
(0.00945)\end{array}$ & $\begin{array}{l}-0.00184 \\
(0.00180)\end{array}$ & $\begin{array}{l}-0.00810 \\
(0.00734)\end{array}$ & $\begin{array}{c}-0.00761 \\
(0.00688)\end{array}$ \\
\hline Tradeoff rel. vs. env. & $\begin{array}{l}-0.00322 \\
(0.00609)\end{array}$ & $\begin{array}{l}-0.00472 \\
(0.00894)\end{array}$ & $\begin{array}{l}0.000833 \\
(0.00160)\end{array}$ & $\begin{array}{c}0.00366 \\
(0.00694)\end{array}$ & $\begin{array}{c}0.00344 \\
(0.00652)\end{array}$ \\
\hline Tradeoff soc. vs. env. & -0.0105 & -0.0154 & 0.00272 & 0.0120 & 0.0113 \\
\hline & $(0.00703)$ & $(0.0103)$ & $(0.00204)$ & $(0.00801)$ & $(0.00750)$ \\
\hline Tradeoff soc. vs. rel. & 0.00732 & 0.0107 & -0.00189 & -0.00833 & -0.00783 \\
\hline & $(0.00651)$ & $(0.00955)$ & $(0.00180)$ & $(0.00742)$ & $(0.00696)$ \\
\hline Internal variables: technology-specific criteria and pre & rences & & & & \\
\hline Landscape & $\begin{array}{c}0.0909 \\
(0.0979)\end{array}$ & $\begin{array}{c}0.133 \\
(0.144)\end{array}$ & $\begin{array}{l}-0.0235 \\
(0.0266)\end{array}$ & $\begin{array}{l}-0.103 \\
(0.111)\end{array}$ & $\begin{array}{l}-0.0972 \\
(0.105)\end{array}$ \\
\hline Local environment & $\begin{array}{c}-0.254^{* *} \\
(0.113)\end{array}$ & $\begin{array}{c}-0.373^{* *} \\
(0.166)\end{array}$ & $\begin{array}{l}0.0658^{*} \\
(0.0369)\end{array}$ & $\begin{array}{c}0.289^{* *} \\
(0.129)\end{array}$ & $\begin{array}{c}0.272^{* *} \\
(0.121)\end{array}$ \\
\hline Local employment & 0.107 & 0.297 & $-0.915^{* * *}$ & $0.433 * * *$ & 0.0790 \\
\hline & $(0.133)$ & $(0.203)$ & $(0.196)$ & $(0.167)$ & $(0.134)$ \\
\hline Sound & $0.177^{* *}$ & $0.260 * *$ & $-0.0458^{*}$ & $-0.202^{* *}$ & $-0.190 * *$ \\
\hline & $(0.0879)$ & $(0.129)$ & $(0.0278)$ & $(0.100)$ & $(0.0937)$ \\
\hline Local economy & -0.0895 & -0.131 & 0.0231 & 0.102 & 0.0957 \\
\hline Health & $\begin{array}{l}(0.0958) \\
-0.0677\end{array}$ & $\begin{array}{c}(0.141) \\
-0.553^{* * *}\end{array}$ & $\begin{array}{l}(0.0261) \\
0.571 * * *\end{array}$ & $\begin{array}{l}(0.109) \\
0.358 * *\end{array}$ & $\begin{array}{c}(0.102) \\
-0.308^{*} *\end{array}$ \\
\hline Heân & $(0.140)$ & $(0.211)$ & $(0.192)$ & $(0.158)$ & $\begin{array}{r}-0.008 \\
(0.138)\end{array}$ \\
\hline Safety & -0.0301 & -0.0441 & 0.00778 & 0.0342 & 0.0322 \\
\hline & $(0.0847)$ & $(0.124)$ & $(0.0221)$ & $(0.0964)$ & $(0.0906)$ \\
\hline Observations & 950 & 950 & 950 & 950 & 950 \\
\hline
\end{tabular}


Table 13: Increased acceptance of wind-farm development under various involvement schemes

\begin{tabular}{|c|c|c|c|c|}
\hline External variables: socio-demographic characteristics & $\begin{array}{c}\text { Community } \\
\text { Benefit }\end{array}$ & $\begin{array}{c}\text { Equity } \\
\text { Involvement }\end{array}$ & Cooperative & $\begin{array}{c}\text { Joint } \\
\text { Venture }\end{array}$ \\
\hline \multicolumn{5}{|l|}{ Age (reference cat.: Younger than 25) } \\
\hline $25-44$ & $\begin{array}{l}-0.0614 \\
(0.0551)\end{array}$ & $\begin{array}{l}-0.0605 \\
(0.0546)\end{array}$ & $\begin{array}{l}-0.0207 \\
(0.0556)\end{array}$ & $\begin{array}{c}0.0394 \\
(0.0569)\end{array}$ \\
\hline \multirow[t]{2}{*}{$45-59$} & 0.0645 & 0.0379 & $0.105^{*}$ & $0.138^{* *}$ \\
\hline & $(0.0589)$ & $(0.0593)$ & $(0.0603)$ & $(0.0608)$ \\
\hline \multirow[t]{2}{*}{60 or older } & 0.115 & 0.00605 & 0.0963 & $0.155^{* *}$ \\
\hline & $(0.0744)$ & $(0.0748)$ & $(0.0762)$ & $(0.0761)$ \\
\hline \multicolumn{5}{|c|}{ Highest level of education (reference cat.: Primary school) } \\
\hline Leaving certificate & $\begin{array}{c}0.0795 \\
(0.0644)\end{array}$ & $\begin{array}{c}0.0868 \\
(0.0659)\end{array}$ & $\begin{array}{c}0.0522 \\
(0.0651)\end{array}$ & $\begin{array}{c}0.0986 \\
(0.0665)\end{array}$ \\
\hline Post-secondary non-tertiary & $\begin{array}{c}0.0778 \\
(0.0663)\end{array}$ & $\begin{array}{c}0.0474 \\
(0.0681)\end{array}$ & $\begin{array}{c}0.0409 \\
(0.0671)\end{array}$ & $\begin{array}{c}0.0464 \\
(0.0684)\end{array}$ \\
\hline Third level non-honours degree & $\begin{array}{c}0.122^{*} \\
(0.0666)\end{array}$ & $\begin{array}{c}0.100 \\
(0.0694)\end{array}$ & $\begin{array}{c}0.0301 \\
(0.0685)\end{array}$ & $\begin{array}{c}0.0702 \\
(0.0705)\end{array}$ \\
\hline Third level honours or above & $\begin{array}{c}0.178^{* * * *} \\
(0.0661)\end{array}$ & $\begin{array}{l}0.149 * * \\
(0.0702)\end{array}$ & $\begin{array}{l}0.165^{* *} \\
(0.0698)\end{array}$ & $\begin{array}{l}0.173^{* *} \\
(0.0713)\end{array}$ \\
\hline \multicolumn{5}{|l|}{ Income (reference cat.: Less than 15,000 ) } \\
\hline 15,000 to 30,000 & $\begin{array}{c}0.0174 \\
(0.0559)\end{array}$ & $\begin{array}{l}-0.0383 \\
(0.0550)\end{array}$ & $\begin{array}{l}-0.0233 \\
(0.0556)\end{array}$ & $\begin{array}{l}-0.0285 \\
(0.0551)\end{array}$ \\
\hline 30,000 to 50,000 & $\begin{array}{l}-0.0316 \\
(0.0595)\end{array}$ & $\begin{array}{l}-0.0207 \\
(0.0584)\end{array}$ & $\begin{array}{c}0.0215 \\
(0.0596)\end{array}$ & $\begin{array}{c}0.0130 \\
(0.0592)\end{array}$ \\
\hline 50,000 to 75,000 & $\begin{array}{c}0.0490 \\
(0.0668)\end{array}$ & $\begin{array}{c}0.0686 \\
(0.0670)\end{array}$ & $\begin{array}{c}0.0688 \\
(0.0679)\end{array}$ & $\begin{array}{c}0.0604 \\
(0.0675)\end{array}$ \\
\hline 75,000 or more & $\begin{array}{c}-0.0792 \\
(0.0754)\end{array}$ & $\begin{array}{l}-0.0258 \\
(0.0754)\end{array}$ & $\begin{array}{l}-0.0105 \\
(0.0758)\end{array}$ & $\begin{array}{c}-0.0362 \\
(0.0738)\end{array}$ \\
\hline \multicolumn{5}{|l|}{ Employment (reference cat.: In employment) } \\
\hline Unemployed, student, home duties, other & $\begin{array}{c}0.0248 \\
(0.0432)\end{array}$ & $\begin{array}{c}0.0374 \\
(0.0433)\end{array}$ & $\begin{array}{c}0.122^{* * * *} \\
(0.0436)\end{array}$ & $\begin{array}{l}0.107 * * \\
(0.0437)\end{array}$ \\
\hline Retired & $\begin{array}{l}-0.0625 \\
(0.0643)\end{array}$ & $\begin{array}{c}0.0501 \\
(0.0645)\end{array}$ & $\begin{array}{c}0.0353 \\
(0.0638)\end{array}$ & $\begin{array}{l}0.00278 \\
(0.0627)\end{array}$ \\
\hline \multicolumn{5}{|l|}{ Gender (reference cat.: Female) } \\
\hline Male & $\begin{array}{c}0.00621 \\
(0.0363)\end{array}$ & $\begin{array}{c}0.0451 \\
(0.0358)\end{array}$ & $\begin{array}{c}0.0488 \\
(0.0360)\end{array}$ & $\begin{array}{c}0.0350 \\
(0.0358)\end{array}$ \\
\hline rented accomodation & $\begin{array}{l}-0.0598 \\
(0.0452)\end{array}$ & $\begin{array}{r}-0.0737^{*} \\
(0.0443)\end{array}$ & $\begin{array}{r}-0.0866^{*} \\
(0.0443)\end{array}$ & $\begin{array}{l}-0.0248 \\
(0.0450)\end{array}$ \\
\hline all other categories of tenure & $\begin{array}{c}-0.103 \\
(0.0831)\end{array}$ & $\begin{array}{l}-0.0677 \\
(0.0822)\end{array}$ & $\begin{array}{l}-0.0831 \\
(0.0801)\end{array}$ & $\begin{array}{c}-0.124 \\
(0.0779)\end{array}$ \\
\hline \multicolumn{5}{|c|}{ Length of residence (reference cat.: Less than 5 years) } \\
\hline $5-20$ years & $\begin{array}{c}0.0209 \\
(0.0530)\end{array}$ & $\begin{array}{l}-0.0180 \\
(0.0527)\end{array}$ & $\begin{array}{l}-0.0452 \\
(0.0526)\end{array}$ & $\begin{array}{c}0.0580 \\
(0.0540)\end{array}$ \\
\hline More than 20 years & $\begin{array}{l}0.00884 \\
(0.0557)\end{array}$ & $\begin{array}{l}-0.0358 \\
(0.0551)\end{array}$ & $\begin{array}{l}-0.0588 \\
(0.0555)\end{array}$ & $\begin{array}{c}0.0407 \\
(0.0560)\end{array}$ \\
\hline Area of residence (reference cat.: Rural) & & & & \\
\hline Urban & $\begin{array}{l}-0.0391 \\
(0.0501)\end{array}$ & $\begin{array}{l}-0.0224 \\
(0.0495)\end{array}$ & $\begin{array}{l}-0.0226 \\
(0.0495)\end{array}$ & $\begin{array}{l}-0.0362 \\
(0.0489)\end{array}$ \\
\hline Internal variables: satisfaction with local planning pr & dures & & & \\
\hline Satisfaction with local planning procedures (ref & ence cat.: Sa & ied) & & \\
\hline Unsatisfied & $\begin{array}{l}-0.0474 \\
(0.0414)\end{array}$ & $\begin{array}{c}0.0383 \\
(0.0413)\end{array}$ & $\begin{array}{c}0.0478 \\
(0.0416)\end{array}$ & $\begin{array}{c}0.0498 \\
(0.0417)\end{array}$ \\
\hline Internal variables: national energy policy preferences & & & & \\
\hline Tradeoff env. vs. econ. & $\begin{array}{l}0.0312^{*} \\
(0.0161)\end{array}$ & $\begin{array}{c}0.0315^{* *} \\
(0.0160)\end{array}$ & $\begin{array}{c}0.0546^{* * *} \\
(0.0162)\end{array}$ & $\begin{array}{c}0.0345^{* *} \\
(0.0160)\end{array}$ \\
\hline Tradeoff rel. vs. econ. & $\begin{array}{c}-0.00875 \\
(0.0196)\end{array}$ & $\begin{array}{l}0.00564 \\
(0.0196)\end{array}$ & $\begin{array}{l}-0.00571 \\
(0.0197)\end{array}$ & $\begin{array}{r}-0.00472 \\
(0.0194)\end{array}$ \\
\hline Tradeoff soc. vs. econ. & $\begin{array}{r}-0.00830 \\
(0.0193)\end{array}$ & $\begin{array}{l}-0.0165 \\
(0.0191)\end{array}$ & $\begin{array}{l}-0.0225 \\
(0.0193)\end{array}$ & $\begin{array}{l}0.00222 \\
(0.0193)\end{array}$ \\
\hline Tradeoff rel. vs. env. & $\begin{array}{c}0.0187 \\
(0.0178)\end{array}$ & $\begin{array}{l}0.00960 \\
(0.0178)\end{array}$ & $\begin{array}{c}0.0134 \\
(0.0178)\end{array}$ & $\begin{array}{l}0.0305^{*} \\
(0.0175)\end{array}$ \\
\hline Tradeoff soc. vs. env. & $\begin{array}{l}-0.0387^{*} \\
(0.0211)\end{array}$ & $\begin{array}{l}-0.0267 \\
(0.0210)\end{array}$ & $\begin{array}{l}-0.0317 \\
(0.0212)\end{array}$ & $\begin{array}{c}-0.0505^{* *} \\
(0.0208)\end{array}$ \\
\hline Tradeoff soc. vs. rel. & $\begin{array}{c}0.0229 \\
(0.0196)\end{array}$ & $\begin{array}{c}0.0166 \\
(0.0194)\end{array}$ & $\begin{array}{c}0.0282 \\
(0.0196)\end{array}$ & $\begin{array}{c}0.0234 \\
(0.0192)\end{array}$ \\
\hline Internal variables: technology-specific criteria and pre & rences & & & \\
\hline Landscape & $\begin{array}{l}-0.138 \\
(0.293)\end{array}$ & $\begin{array}{c}0.154 \\
(0.287)\end{array}$ & $\begin{array}{l}0.0759 \\
(0.289)\end{array}$ & $\begin{array}{c}0.185 \\
(0.291)\end{array}$ \\
\hline Local environment & $\begin{array}{c}0.232 \\
(0.330)\end{array}$ & $\begin{array}{c}0.218 \\
(0.324)\end{array}$ & $\begin{array}{l}-0.236 \\
(0.327)\end{array}$ & $\begin{array}{l}-0.452 \\
(0.327)\end{array}$ \\
\hline Local employment & $\begin{array}{c}-0.00876 \\
(0.271)\end{array}$ & $\begin{array}{c}0.225 \\
(0.267)\end{array}$ & $\begin{array}{c}0.190 \\
(0.270)\end{array}$ & $\begin{array}{c}0.345 \\
(0.271)\end{array}$ \\
\hline Sound & $\begin{array}{c}-0.516^{* *} \\
(0.256)\end{array}$ & $\begin{array}{l}-0.346 \\
(0.253)\end{array}$ & $\begin{array}{l}-0.336 \\
(0.254)\end{array}$ & $\begin{array}{l}-0.328 \\
(0.253)\end{array}$ \\
\hline Local economy & -0.264 & -0.392 & -0.247 & -0.368 \\
\hline & $(0.284)$ & $(0.283)$ & $(0.284)$ & $(0.284)$ \\
\hline Health & $\begin{array}{c}0.721^{* *} \\
(0.286)\end{array}$ & $\begin{array}{c}0.190 \\
(0.284)\end{array}$ & $\begin{array}{c}0.291 \\
(0.284)\end{array}$ & $\begin{array}{c}0.492^{*} \\
(0.283)\end{array}$ \\
\hline Observations & 951 & 933 & 930 & 926 \\
\hline
\end{tabular}


Table 14: Increased acceptance of transmission-grid expansion under various involvement schemes

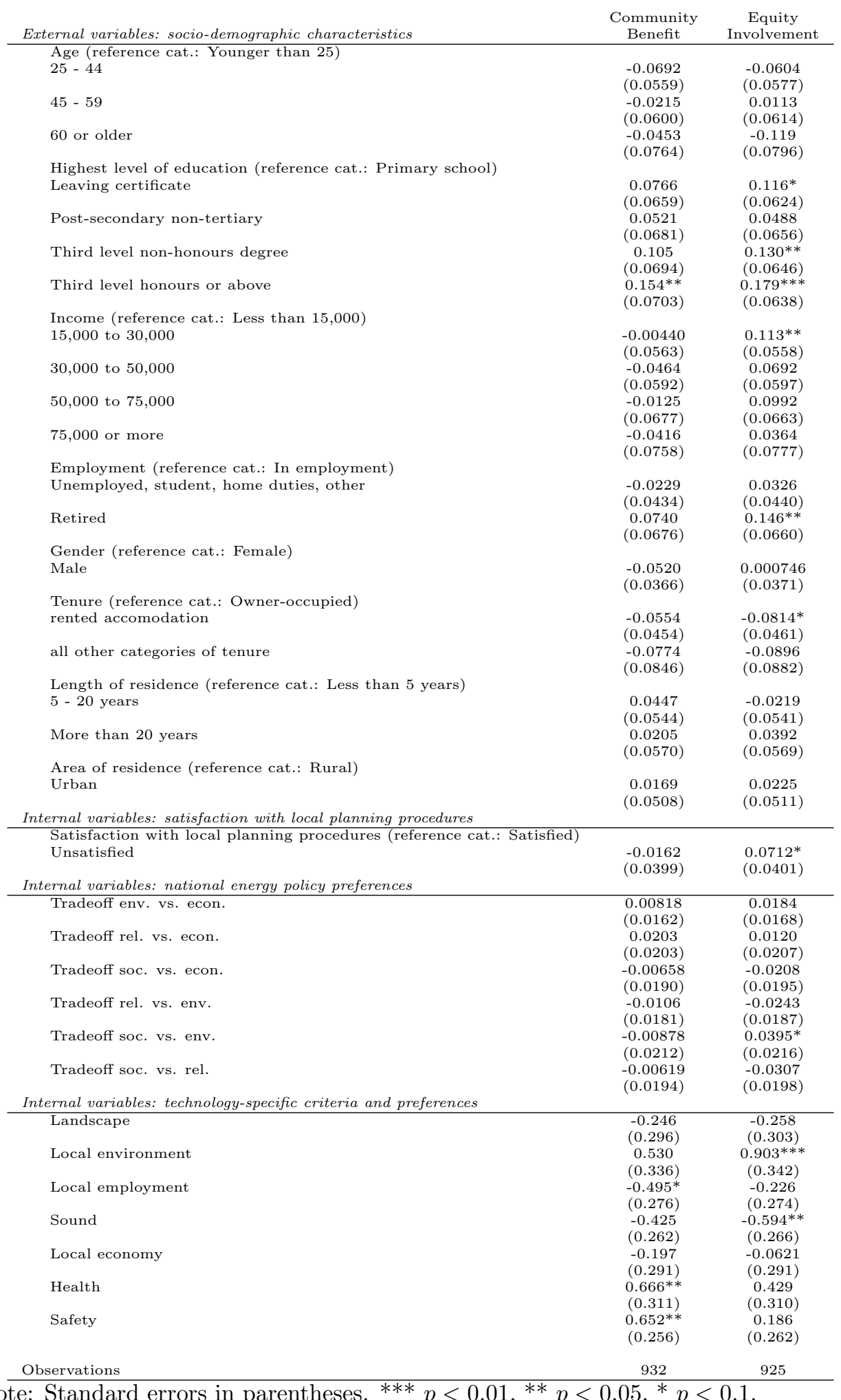

Note: Standard errors in parentheses. ${ }^{* * *} p<0.01,{ }^{* *} p<0.05,{ }^{*} p<0.1$. 